\title{
Environmental Management Performance Report March 2000
}

Prepared for the U.S. Department of Energy

Assistant Secretary for Environmental Management

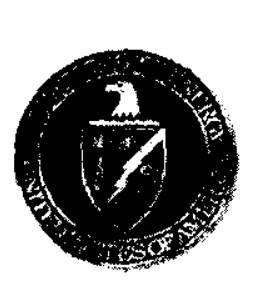

\section{United States}

\section{Department of Energy}

Richland Operations Office

P.O. Box 550

Richland, Washington 99352

Approved for Public Release; Further Dissemination Unlimited 


\section{RELEASE AUTHORIZATION}

Document DOE/RL-99-83

Number: Revision 2

Document Title: 2000

This document, reviewed in accordance with DOE Order 241.1, "Scientific and Technical Information Management, "and 241.1-1, "Guide to the Management of Scientific and Technical Information," does not contain classified or sensitive unclassified information and is:

\section{APPROVED FOR PUBLIC RELEASE}

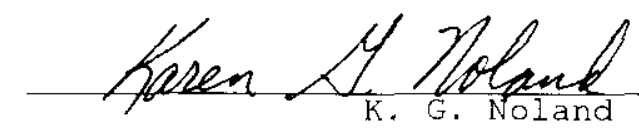




\section{INFORMATION CLEARANCE I:I JRM}

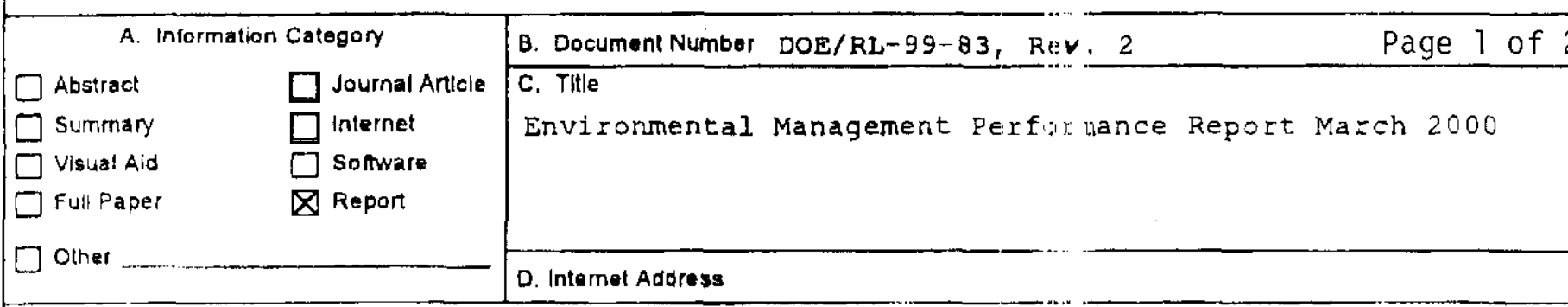

E. Require dinformation

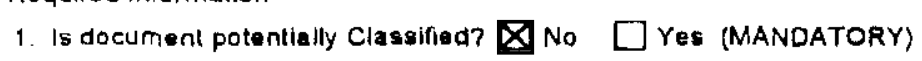
L.E. maiden

\section{Manager's Signature Required}

If Yes ADC signature Required

2. Internai Revlew Required? If Yes, Document Signatures Below - $\square$ No

Yes Clasedinad Counsel

Program

3. Referances in the Information are Applied Technology $\bigotimes_{\text {No }} \square$ Yes Expon Controlled Information $\otimes_{\text {No }} \square$ Yas $\square$ No $\square$ res

F. Complele for a Journal Article

1. Thile of Journal

\section{G. Complate for a Presentalion}

1. Tille for Conference or Meeting

2. Group Sponsoring

3 Date of Conference

5. Wil information be Published in Proceedings? $\square$ No $\square$ Yes H. Author/Requestor (Print and Sign)

I. Reviewers

Yes Print

4. City/State

General Counse

$\square$

Orfice of External Altairs

DOE-RL

Other

$\bigotimes$ C. Willingham

6. Wil Materlal bis | anded Out? Responsible Ma
L.E. Ma Idu:
(Print and Sign!

Signature

a. New or Novisl , 'atentable) Subject Mattor? $\square$ No $\square$ Yes II "Yos", Dis :

b. Information fli sived in Confidence. Such as Propriatary and/or inventions?

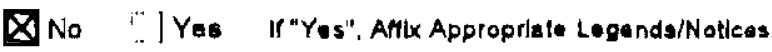

c. Copyrights? $\square$ No $\square$ Yes If "Yes", Antach Permission.

d. Trademarks" $\square$ No $\square$ Yes if "Yos", Identlfy in Dosument.

5. Is Information ua: Ifring submission to OSTI? $\square$ No $\square$ Yes If Yes $U C-\ldots \ldots$ ano $B S R-$

6. Rolease Level" $\searrow$ Pubtic $\square$ Limiled

7. Charge codo_: 000

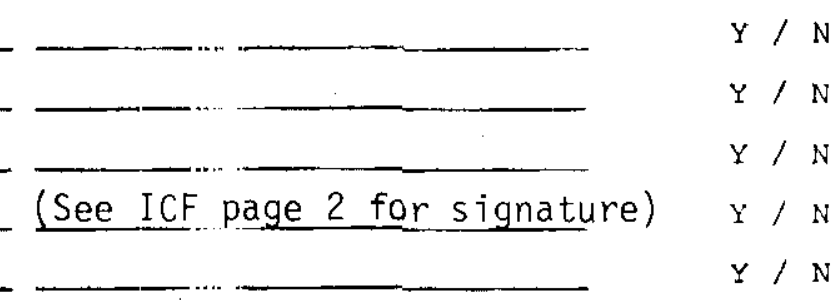

Other

ए

J if information includes Sensitive information and is not to be reloased to the Public indicate cillia fory below

$\square$ Applied Technology $\square$ Protected CRADA

$\square$ Personal/Private

$\square$ proprietary

$\square$ Business-Sensitive

$\square$ Export Controlied

[ Predecisional

$\square$ Procurement-Sensitive

$\square$ Predecisi
$\square$ UCN!

$\square$ Patentabis

Other (Specify)

K. Il Addltional Comments, Plesse Attach Separate Sheet

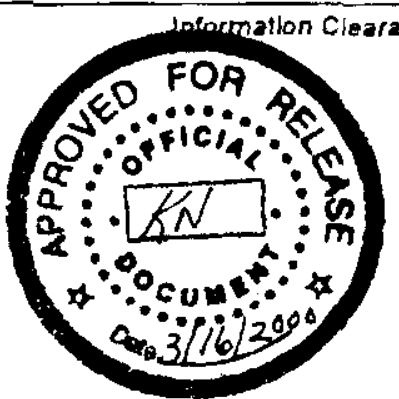




\section{INFORMATION CLEARANCE FORM}

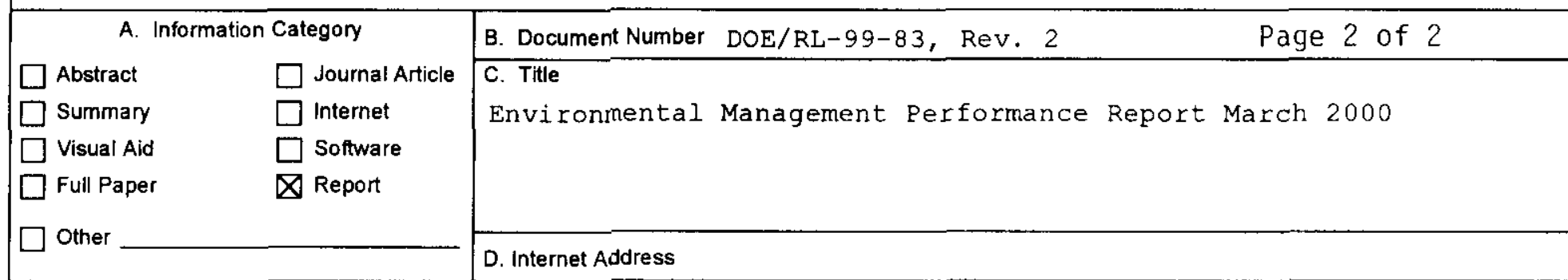

E. Required Information

1. Is document potentially Classified? $\square$ No $\square$ Yes (MANDATORY) L.E. Maiden Manager's Signature Required

If Yes ADC Signature Required

2. Internal Review Required? If Yes, Document Signatures Below

$\bigotimes$ No $\square$ Yes

Counsel

Program

3. References in the information are Applied Technology $\bigotimes$ No $\square$ Yes Export Controlled Information $\bigotimes_{\text {No }} \square$ Yes
4. Does Information Contain the Following: (MANDATORY)

a. New or Novel (Patentable) Subject Matter? $\quad$ No $\square$ Yes

If "Yes", Disclosure No.:

b. Information Received in Confidence, Such as Proprietary and/or Inventions? $\bigotimes$ No $\square$ Yes If "Yes", Affix Appropriate Legends/Notices.

c. Copyrights? $\square$ No $\square$ Yes If "Yes", Attach Permission.

d. Trademarks? $\square$ No $\square$ Yes If "Yes", Identify in Document.

5. Is Information requiring submission to OSTI? $\square$ No $\square$ Yes If Yes $U C$ -

6. Release Level? $\square$ Public $\square$ Limited

7. Charge Code 08000 tIMFD-1221

\section{F. Complete for a Journal Article}

1. Title of Journal

\section{G. Complete for a Presentation}

1. Title for Conference or Meeting

2. Group Sponsoring

3. Date of Conference

4. City/State

5. Will Information be Published in Proceedings? $\square$ No $\square$ Yes

6. Will Material be Handed Out? $\square$ No $\square$ Yes

H. Author/Requestor Responsible Manager

D.M. Eder (Print and Sign)

L.E. Maiden (Print and Sign)

\begin{tabular}{|c|c|c|c|c|}
\hline 1. Reviewers & Yes & Print & Signature & Public $\mathrm{Y} / \mathrm{N}$ (If $\mathrm{N}$, com \\
\hline General Counsel & $\square$ & & & $\mathrm{Y} / \mathrm{N}$ \\
\hline Office of External Affairs & $\square$ & & & $\mathrm{Y} / \mathrm{N}$ \\
\hline DOE-RL & $\square$ & & & $\mathrm{Y} / \mathrm{N}$ \\
\hline Other & $\bigotimes$ & C. Willingham & & \\
\hline Other & & & & $\mathrm{Y} / \mathrm{N}$ \\
\hline
\end{tabular}

$\mathrm{J}$. If Information Includes Sensitive Information and is not to be released to the Public indicate category below.

$\square$ Applied Technology $\square$ Protected CRADA

$\square$ Personal/Private $\square$ Export Controlled

$\square$ Proprietary $\square$ Procurement-Sensitive

$\square$ Business-Sensitive $\square$ Patentable

$\square$ Predecisional $\quad \square$ Other (Specify)

$\square$ UCNI

K. If Additional Comments, Please Attach Separate Sheet 


\section{Environmental Management Performance Report March 2000}

www. hanford.gov/empr/toc. htm

Prepared for the U.S. Department of Energy

Assistant Secretary for Environmental Management.

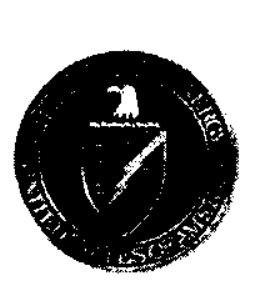

United States

Department of Energy

Richland Operations Office

P.O. Box 550

Richland, Washington 99352

Approved for Public Release; Further Dissemination Unlimited 


\section{TRADEMARK DISCLAIMER}

Reference herein to any specific commercial product, process, or service by trade name, trademark, manufacturer, or otherwise, does not necessarily constitute or imply its endorsement, recommendation, or favoring by the United

States Government or any agency thereof or its contractors or subcontractors.

This report has been reproduced from the best available copy. Available in paper copy and microfiche.

Available electronically at hitp:/www.doe.gov/bridge. Available for a processing fee to the U.S. Department of Energy and its contractors, in paper, from:

U.S. Department of Energy

Office of Scientific and Technical Information

P.O. Box 62

Oak Ridge, TN 37831-0062

phone: $865-576-8401$

fax: 865-576-5728

email: reports@adonis.osti.gov(423) 576-8401

Available for sale to the public, in paper, from:

U.S. Department of Commerce

National Technical Information Service

5285 Port Royal Road

Springfield, VA 22161

phone: 800-553-6847

fax: 703-605-6900

email: orders@ ntis.fedworld.gov

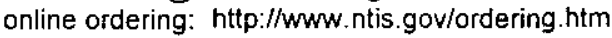




\section{INTRODUCTION}

The purpose of the Environmental Management Performance Report (EMPR) is to provide the Department of Energy Richland Operations Office's (DOE-RL's) report of Hanford's Environmental Management (EM) performance by:

- U. S. Department of Energy, Richland Operations Office,

- Project Hanford Management Contract (PHMC) through Fluor Hanford, Inc. (FHI) and its subcontractors,

- Environmental Restoration Contract through Bechtel Hanford, Inc. (BHI), and its subcontractors, and

- Pacific Northwest National Laboratories (PNNL) for EM and EM Science and Technology (S\&T) Mission.

This report is a monthly publication that summarizes EM Site performance under RL Operations Office. It is organized by the four sections listed above, with each section containing an Executive Summary and Area Performance Summaries. 


\section{PHMC Environmental Management Performance Report March 2000}

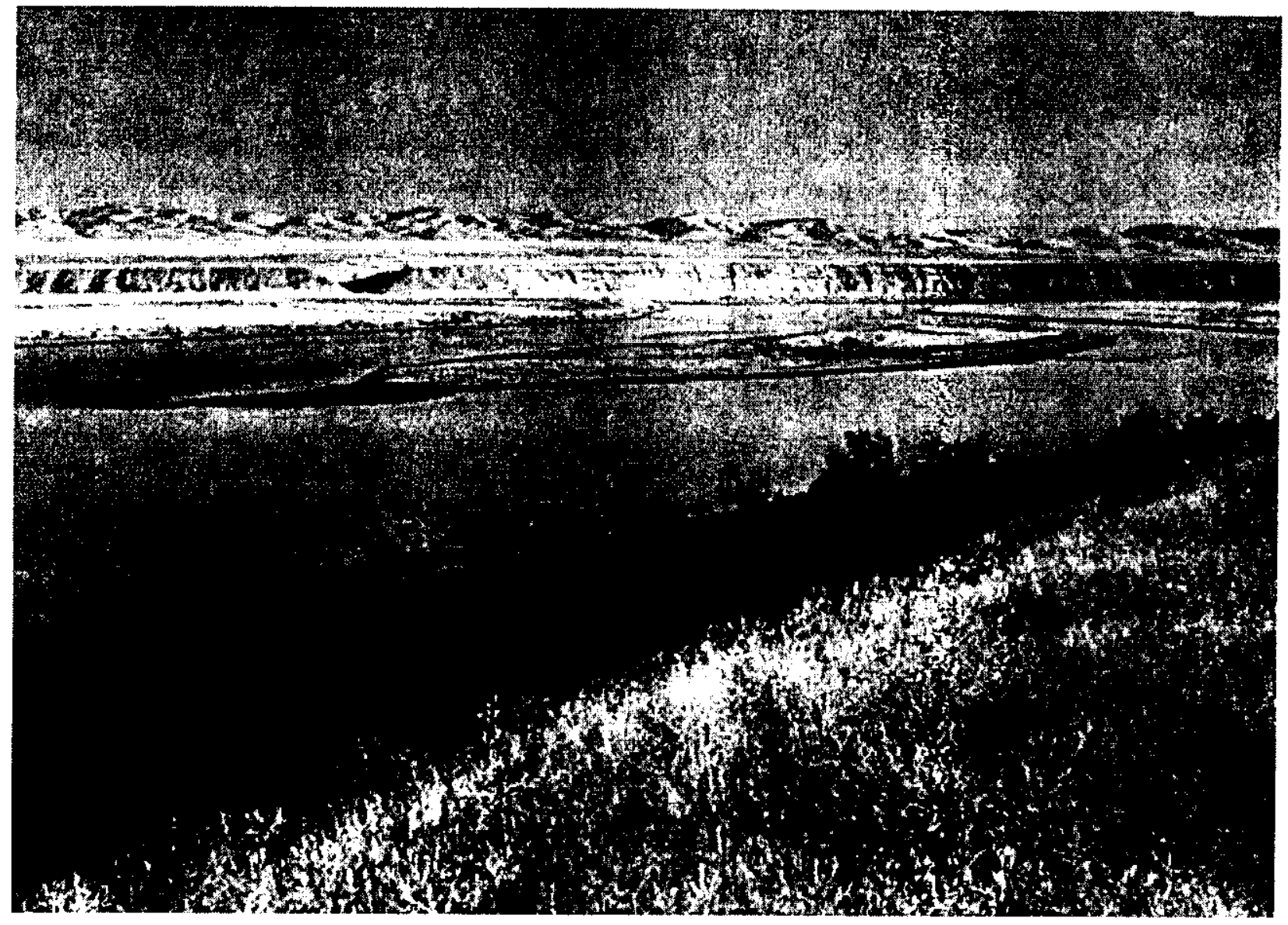

\section{Fluor Hanford}

A Fluor Global Services Company 


\section{Table of Contents}

Section

A. Executive Summary

B: 1. Waste Management

B: 2. Analytical Services (222-S, HASP, WSCF)

C. Spent Nuclear Fuel

D: 1. Nuclear Material Stabilization

D: 2. River Corridor

E. Landlord

F. Support

c. HAMMER

H. Advanced Reactors Transition

1. EM - 50 Science \& Technology Activities

J. National Programs

Glossary 


\section{INTRODUCTION}

$\mathrm{T}$ he purpose of this report is to provide the Department of Energy Richland Operations Office (DOE-RL) a report of the Project Hanford Management Contractors' (PHMC) Environmental Management (EM) performance by Fluor Hanford (FH) and its subcontractors. This report is a monthly publication that summarizes the PHMC EM performance. In addition, it includes some PHMC-level data not detailed elsewhere in the report.

Section A, Executive Summary, provides an executive level summary of the cost, schedule, and technical performance described in this report. It summarizes performance for the period covered, highlights areas worthy of management attention, and provides a forward look to some of the upcoming key performance activities as extracted from the PHMC baseline.

The remaining sections provide detailed performance data relative to each individual mission area (e.g., Waste Management, Spent Nuclear Fuels, etc.), in support of Section A of the report. A glossary of terms is provided at the end of this report for reference purposes. Unless otherwise noted, the Safety, Conduct of Operations, and Cost/Schedule data contained herein is as of January 31, 2000. All other information is as of March 1, 2000. 

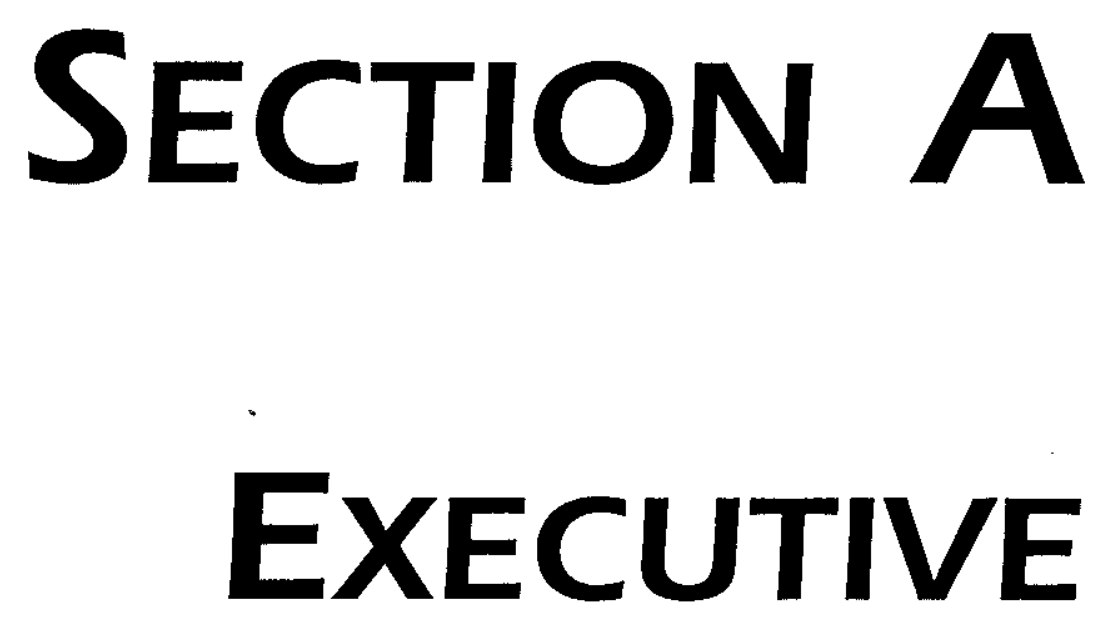

SUMMARY 


\section{INTRODUCTION}

This section provides an executive level summary of the performance information covered in this report and is intended to bring to Management's attention that information considered to be most noteworthy. All cost, schedule, milestone commitments, and safety data is current as of January 31. Accomplishments, Issues and Integration items are current as of March 1 unless otherwise noted.

The section begins with a description of notable accomplishments that have occurred since the last report and are considered to have made the greatest contribution toward safe, timely, and costeffective clean up. Following the accomplishment section is an overall fiscal year-to-date summary analysis addressing cost, schedule, and milestone performance. Overviews of safety ensue. The next segment of the Executive Summary, entitled Critical Issues, is designed to identify the high-level challenges to achieving cleanup progress.

The Key Integration Activities section follows next, highlighting PHMC activities that cross contractor boundaries and demonstrate the shared value of partnering with other Site entities to accomplish the work. Concluding the Executive Summary, a forward-looking synopsis of Upcoming Planned Key Events is provided.

\section{NOTABLE ACCOMPLISHMENTS}

- A total of 173 cans of Plutonium oxides and sludges have been stabilized through thermal stabilization (9 items in January 2000).

- A total of 13 liters of Plutonium nitrate solution have been stabilized in the prototype vertical denitration calciner.

- Progress continues on the installation of three additional muffle furnaces for thermal stabilization of polycubes and on installation of the $\mathrm{Mg}(\mathrm{OH})_{2}$ process glovebox.

- The Canister Storage Building (CSB) is 95 percent complete, compared to 95 percent planned. The Cold Vacuum Drying (CVD) Facility is 89 percent complete compared to 91 percent planned.

- The Carlsbad Area Office (CAO) audit of Hanford's Transuranic (TRU) Project to meet the requirements of the new Part B Waste Isolation Pilot Plant (WIPP) Resource Conservation and Recovery Act (RCRA) Permit was completed in January. EPA is going to recommend qualification of the Hanford site TRU QA Program.

- Over 4,000 cubic feet (FYTD) of mixed low-level waste were shipped to ATG for non-thermal treatment. ATG completed four macro-encapsulated waste containers to date, and preparations are on schedule to receive the first treated waste shipment into, the Mixed Waste Disposal trenches in February. 
- Acceleration of deactivation at the 327 Facility made good progress in January. Transfer of forty specimen containers from dry storage was completed. To date, sixty-nine specimen containers out of approximately 300 planned have been transferred.

\section{Performance Data ANd ANalysis}

The following provides a brief synopsis of overall PHMC Environmental Management (EM) cost, schedule, and milestone performance.

\section{FY 2000 Cost and Schedule Performance}

Cost Performance - Fiscal-year-to-date (FYTD) cost performance reflects a one percent $(\$ 1.4$ million) unfavorable cost variance that is within the established $+10 /-5$ percent threshold.

Schedule Performance - There is a FYTD six percent ( $\$ 11.2$ million) unfavorable schedule variance.

Data Through January 2000

\begin{tabular}{|c|c|c|c|c|c|c|c|}
\hline & & \multirow{3}{*}{$\begin{array}{c}\text { Total } \\
\text { FY PTS } \\
\text { BCWS }\end{array}$} & \multicolumn{5}{|c|}{ Current Fiscal Year Performance (S x Million) } \\
\hline & & & \multicolumn{3}{|c|}{ FYTD } & \multirow{2}{*}{$\begin{array}{l}\text { Schedule } \\
\text { Variance }\end{array}$} & \multirow{2}{*}{$\begin{array}{c}\text { Cost } \\
\text { Variance }\end{array}$} \\
\hline & & & BCWS & BCWP & ACWP & & \\
\hline 1.2 & $\begin{array}{l}\text { Waste Management } \\
\text { TP02,WM03-05 }\end{array}$ & 109.7 & 31.9 & 29.2 & 28.6 & $(2.7)^{*}$ & 0.6 \\
\hline 1.2 .4 & $\begin{array}{l}\text { Analytical Sves (222-S, HASP,WSCF) } \\
\text { WMO6 }\end{array}$ & 27.6 & 8.8 & 8.7 & 8.8 & $(0.1)$ & $(0.1)$ \\
\hline 1.3 & $\begin{array}{l}\text { Spent Nuclear Fuel } \\
\text { whos }\end{array}$ & 195.1 & 55.5 & 47.0 & 62.4 & $(8.5)$ & $(15.4)$ \\
\hline 1.4 .5 & $\begin{array}{l}\text { Nuclear Materials Stabilization } \\
\text { TP05 }\end{array}$ & 127.9 & 41.2 & 35.9 & 30.4 & $(5.3)$ & 5.5 \\
\hline 1.4 & $\begin{array}{l}\text { River Corridor } \\
\text { TP01,TP04,TP08,TP10,TP12,TP14 }\end{array}$ & 60.8 & 16.8 & 16.6 & 16.5 & $(0.2)$ & 0.1 \\
\hline 1.5 & $\begin{array}{l}\text { Landlord } \\
\text { TP13 }\end{array}$ & 14.3 & 3.9 & 2.9 & 1.4 & $(1.0)$ & 1.5 \\
\hline 1.8 & $\begin{array}{l}\text { Mission Support } \\
\text { OT01, OT04 }\end{array}$ & 35.9 & 9.6 & 17.4 & 11.3 & 7.8 & 6.1 \\
\hline 1.9 & $\begin{array}{l}\text { HAMMIER } \\
\text { HMOI }\end{array}$ & 5.5 & 1.7 & .1 .7 & 1.6 & 0.0 & 0.1 \\
\hline \multirow[t]{2}{*}{1.12} & Advanced Reactors (EM) & 1.3 & 0.4 & 0.4 & 0.4 & 0.0 & 0.0 \\
\hline & PHMC EM Clean-Up Projects & $5 \overline{578.1}$ & 169.8 & 159.8 & 161.4 & $(10.0)$ & $(1.6)$ \\
\hline \multirow[t]{3}{*}{1.11} & $\begin{array}{l}\text { NationaIPrograms } \\
\text { OT02-03, OT06, WMM07 }\end{array}$ & 5.8 & 1.3 & 1.0 & 1.4 & $(0.3)$ & $(0.4)$ \\
\hline & $\begin{array}{l}\text { Technology Development } \\
\text { (E.1-50) }\end{array}$ & 23.6 & 6.9 & 6.0 & 5.4 & $(0.9)$ & 0.6 \\
\hline & Total Other Projects & 29.4 & 8.2 . & 7.0 & 6.8 & $(1.2)$ & 0.2 \\
\hline & TotalPHMC Projects & 607.5 & T78.0 & 166.8 & T68.2 & $(11.2)$ & $(1.4)$ \\
\hline
\end{tabular}

Notes: Column headings (BCWS, BCWP, etc.) are defined in the glossary at the end of the report. Calculations are based on Project Baseline Summary detail. Waste Management and Nuclear Materials Stabilization have included RL-Directed costs (e.g. steam and laundry) in the PEM BCWS. Advanced Reactors (EM) have included steam. 
The following Cost/Schedule and Variance to Plan charts provide an overall graphical view of fiscal year to date performance. In addition, the first chart shows the budget phasing for the entire year. The second chart portrays cost and schedule performance indicators.

FY 2000 Cost / Schedule Performance

Cumulative to Date Status

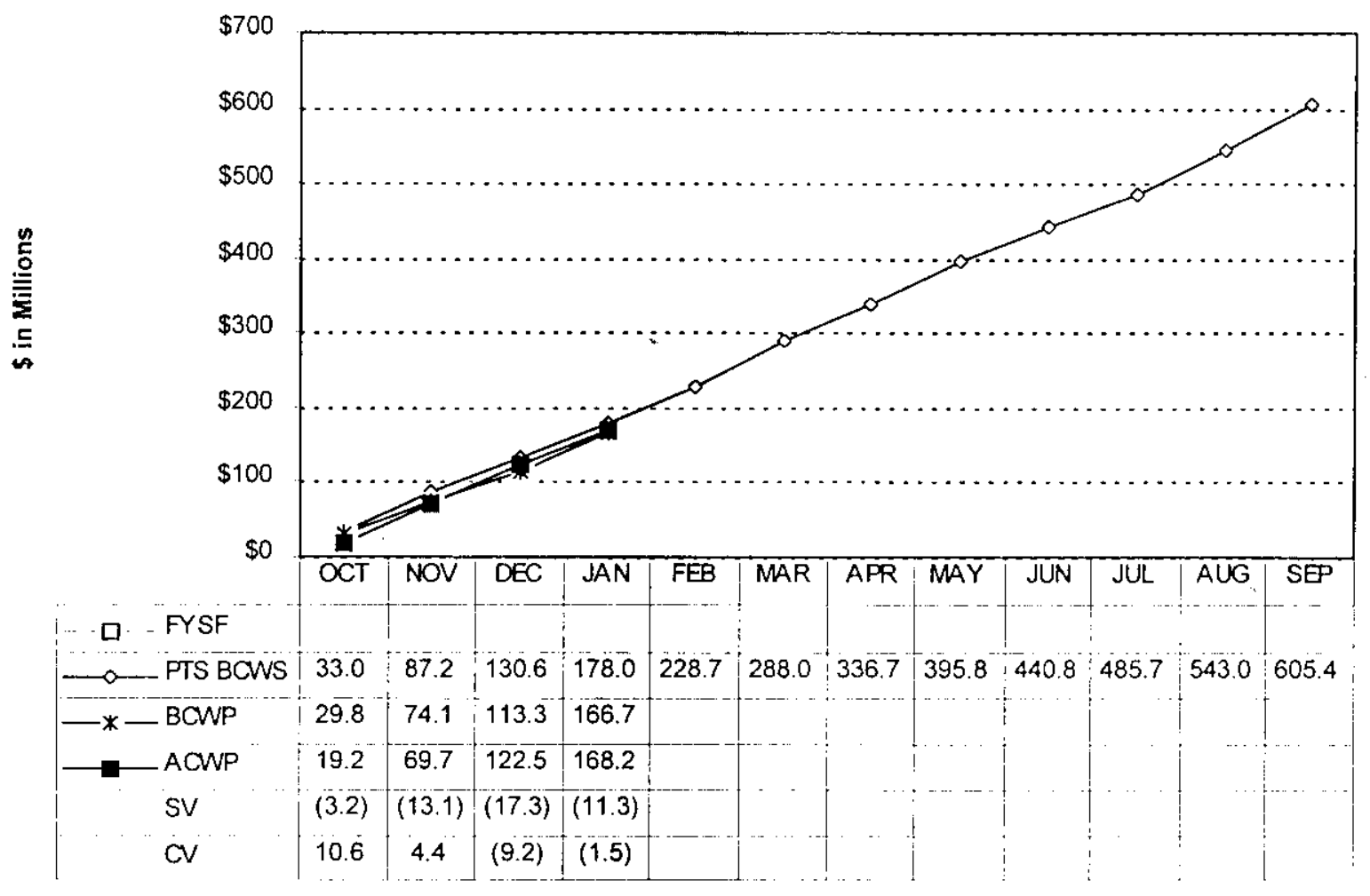




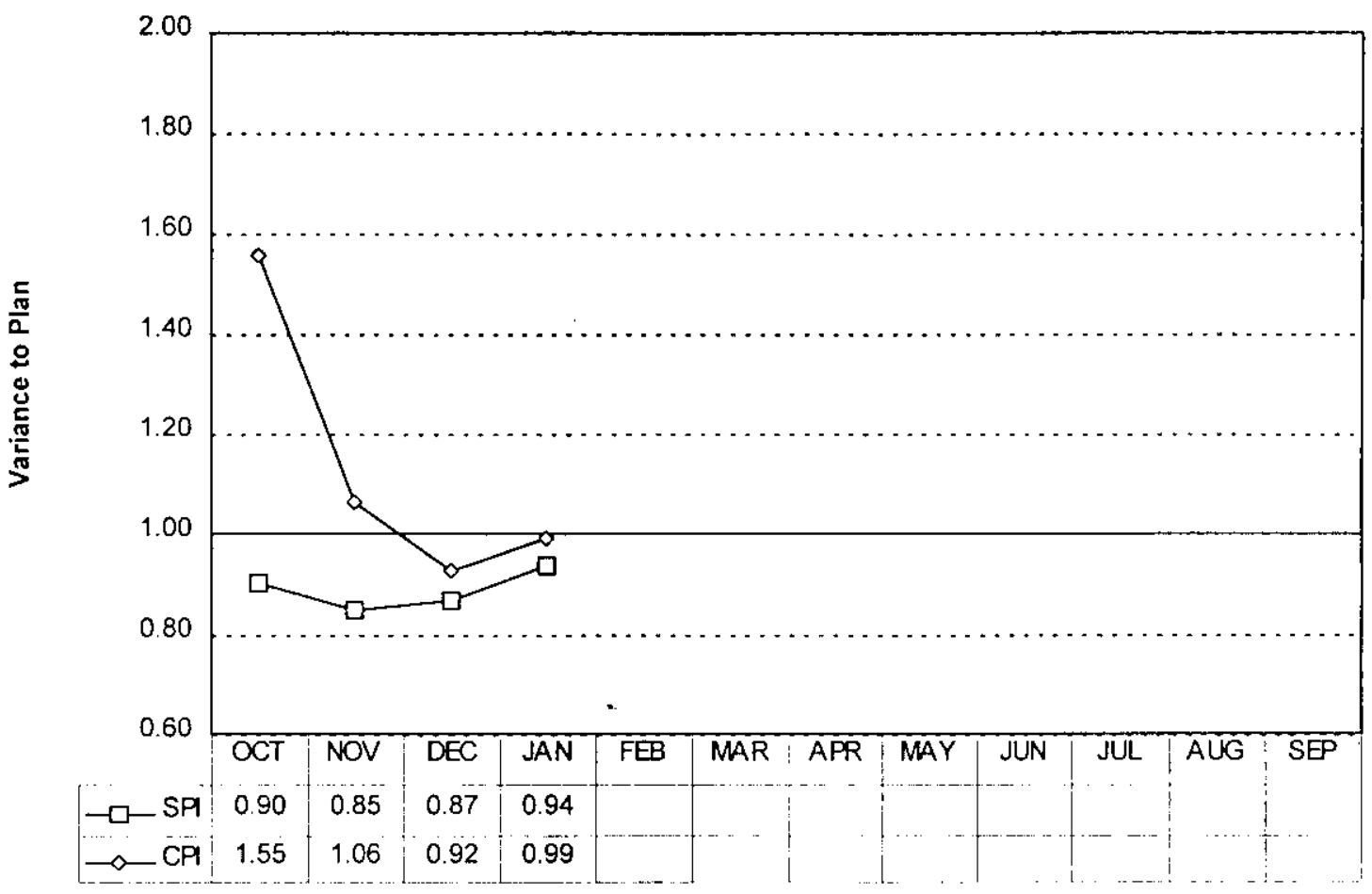

\section{Milestone Performance}

Milestones represent significant events in project execution. They are established to provide a higher level of visibility to critical deliverables and to provide specific status about the accomplishment of these key events. Because of the relative importance of milestones, the ability to track and assess milestone performance provides an effective tool for managing the PHMC EM cleanup mission.

FYTD milestone performance (Enforceable Agreement [EA.], U.S. Department of Energy-Headquarters [DOE-HQ], and RL) shows that 3 of 12 approved baseline milestones (25 percent) were completed on or ahead of schedule and 9 milestones ( 75 percent) are overdue. The nine overdue milestones are associated with four projects: Nuclear Material Stabilization-one, River Corridor-five, Environmental Management (EM)-50 - three, and Mission Support-one. These overdue milestones do not share a common cause. Milestone baseline totals have been revised to show PHMC milestones only; prior reports may have included other project milestones.

In addition to the FY2000 milestones described above, there are four overdue milestones from the prior fiscal year (FY1999). Further details regarding these milestones may be found in the Project Sections.

FY 2000 information is depicted graphically below and on the following page. For additional details related to the data in the graphs and prior year milestones, refer to the relevant project section titled "Milestone Exception Report."

FY 2000 information reflects the current approved baseline. Changes in both the number and type of milestones from month to month are the result of Baseline Change Requests (BCRs) approved during the year. 


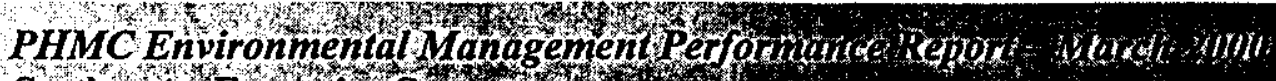

Section A-Executive Summary,

\begin{tabular}{|r|r|r|r|r|r|r|r|r|}
\hline & \multicolumn{3}{|c|}{ FISCAL YEAR-TO-DATE } & \multicolumn{2}{c|}{ REMAINING SCHEDULED } & TOTAL \\
\cline { 2 - 8 } MILESTONE TYPE & $\begin{array}{c}\text { Completed } \\
\text { Early }\end{array}$ & $\begin{array}{c}\text { Completed } \\
\text { On } \\
\text { Schedule }\end{array}$ & $\begin{array}{c}\text { Completed } \\
\text { Late }\end{array}$ & Overdue & $\begin{array}{c}\text { Forecast } \\
\text { Early }\end{array}$ & $\begin{array}{c}\text { Forecast On } \\
\text { Schedule }\end{array}$ & $\begin{array}{c}\text { Forecast } \\
\text { Late }\end{array}$ & $\begin{array}{c}\text { FY } \\
\mathbf{2 0 0 0}\end{array}$ \\
\hline Enforceable Agreement & 2 & 0 & 0 & 0 & 0 & 5 & 0 & 7 \\
\hline DOE-HQ & 0 & 0 & 0 & 1 & 0 & 1 & 0 & 2 \\
\hline RL & 1 & 0 & 0 & 8 & 0 & 84 & 4 & 97 \\
\hline Total Project & 3 & 0 & 0 & 9 & 0 & 90 & 4 & 106 \\
\hline
\end{tabular}
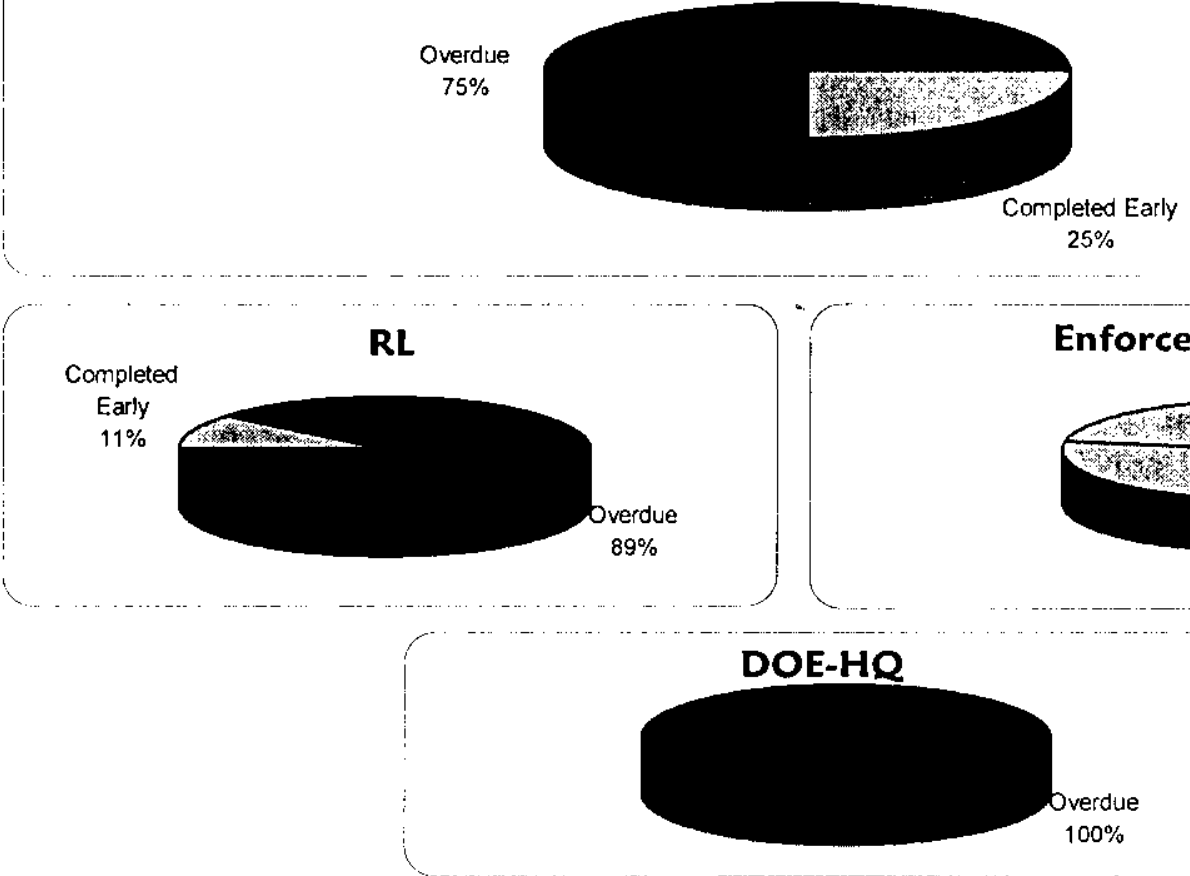
MILESTONE EXCEPTIONS
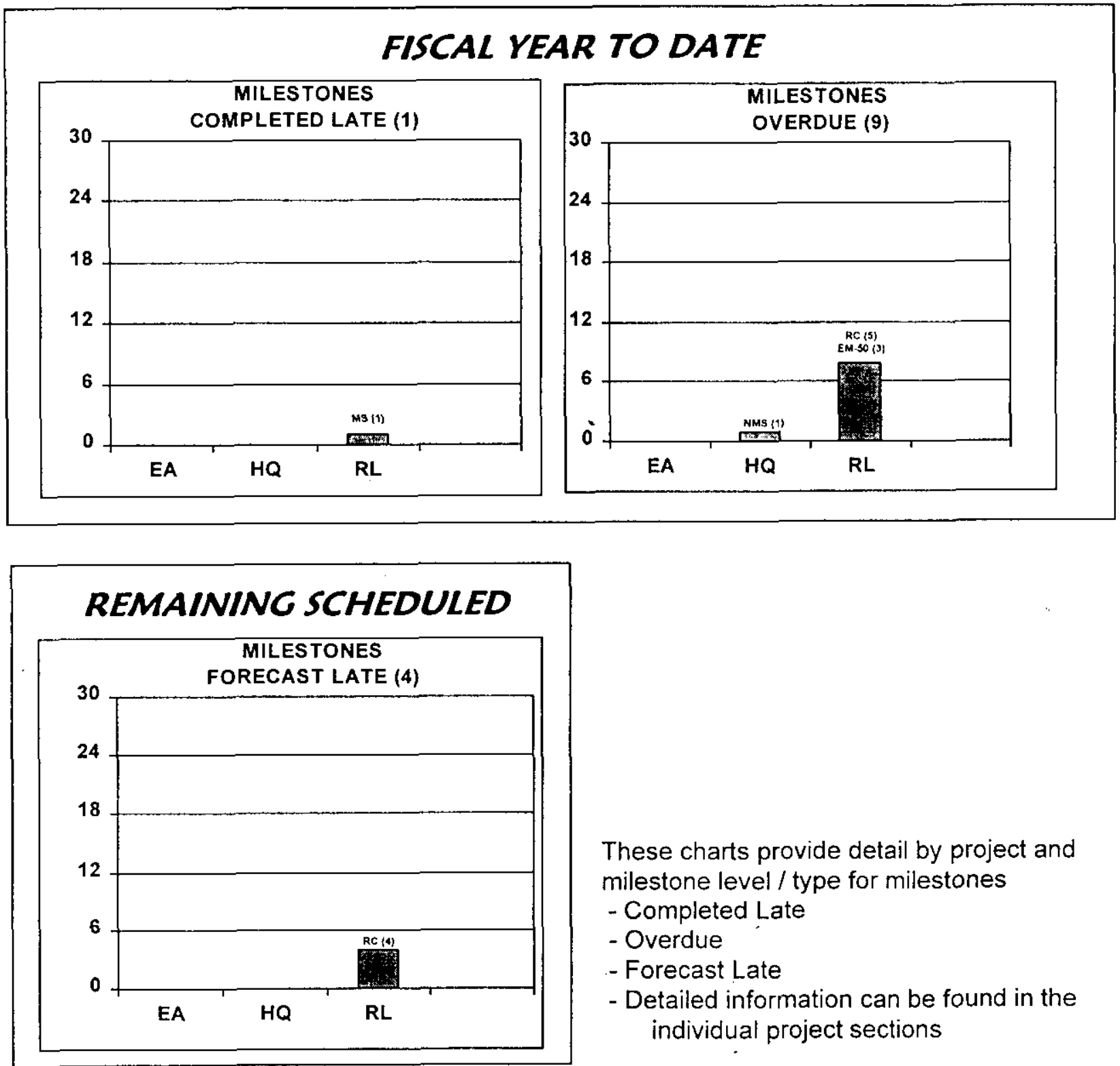

These charts provide detail by project and milestone level / type for milestones

- Completed Late

- Overdue

- Forecast Late

- Detailed information can be found in the individual project sections 


\section{SAFETY OVERVIEW}

The focus of this section is to document trends in occurances. Improvements in these rates are due to the efforts of the PHMC workforce as they implement the Integrated ES\&H

Management System (ISMS), work towards achieving Voluntary Protection Program (VPP) "star" status, and accomplish work through Enhanced Work Planning (EWP). Safety and health statistical data is presented in this section.

\section{Significant SafeTy and Health Events}

PHMC Statistics - Rates have been stable for nearly two years. This safety performance plateau has been recognized, and Fluor Hanford kicked off its Integrated Safety Approach initiative on December 6,1999 in order to take safety performance to a new level. This initiative focuses upon the "people side" of accident prevention.

\section{Total OSHA Reciordable Case Rate}

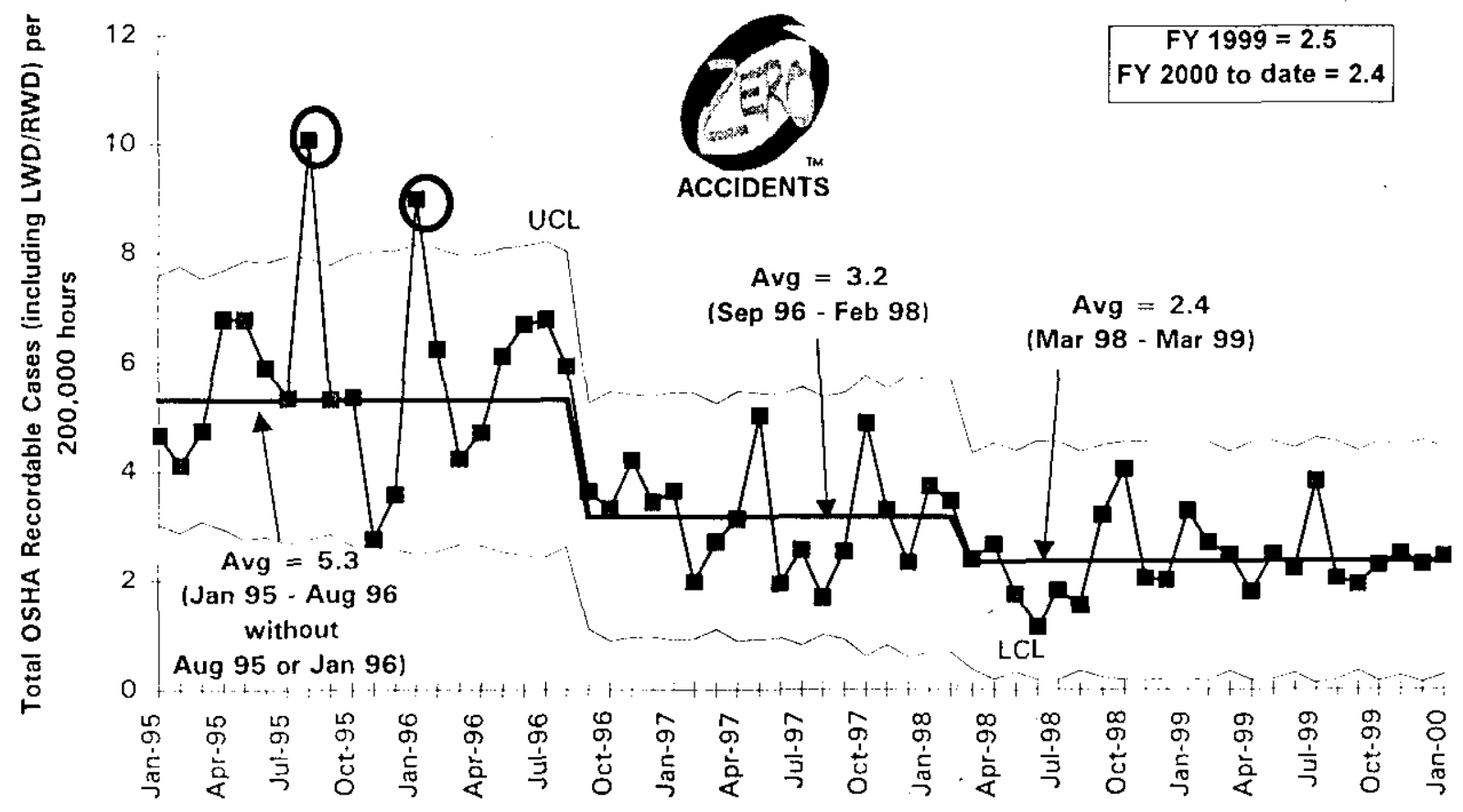




\section{OSHA LOST/RESTRICTED WORKDAY CASE RATE}

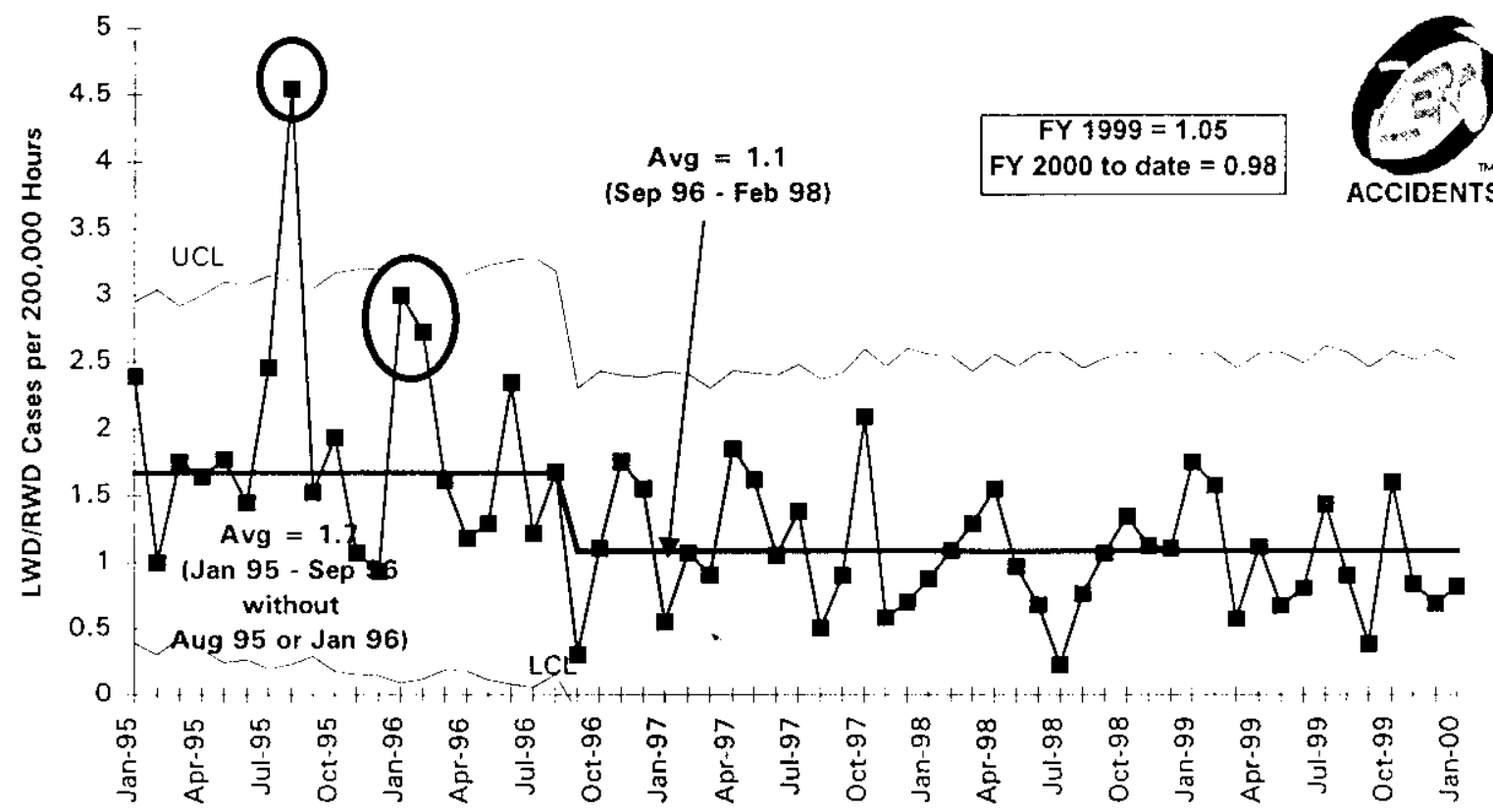

First Aid Case Rate

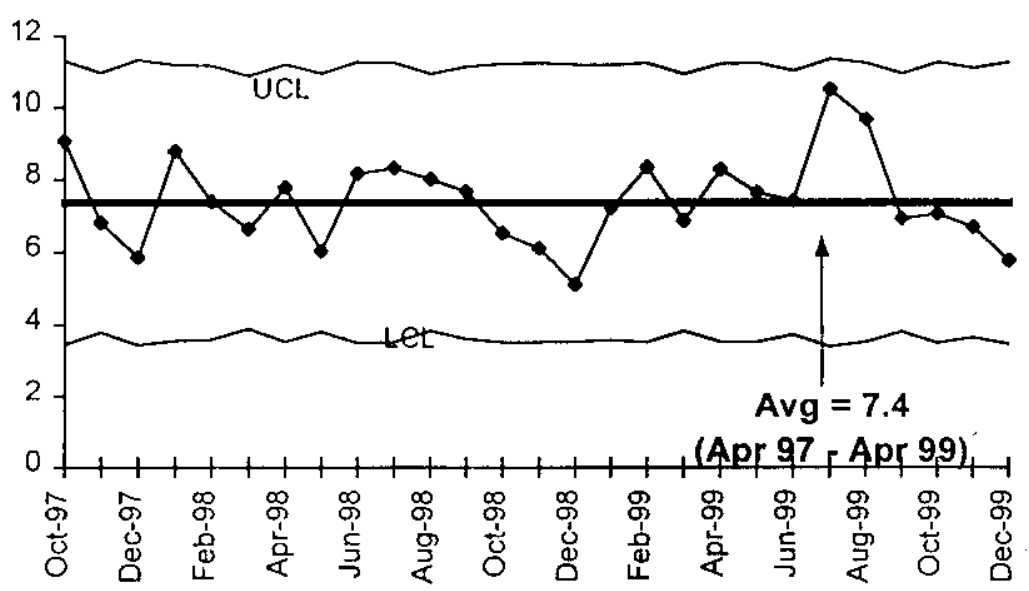

First Aid Rate undergoes seasonal cycles.

Increases occur in warmer weather due to insect and animai encounters, and due to wind related minor injuries. The previously noted summer 1999 increase reduced due to case reclassifications. 


\section{DOE Safety Cost Index}

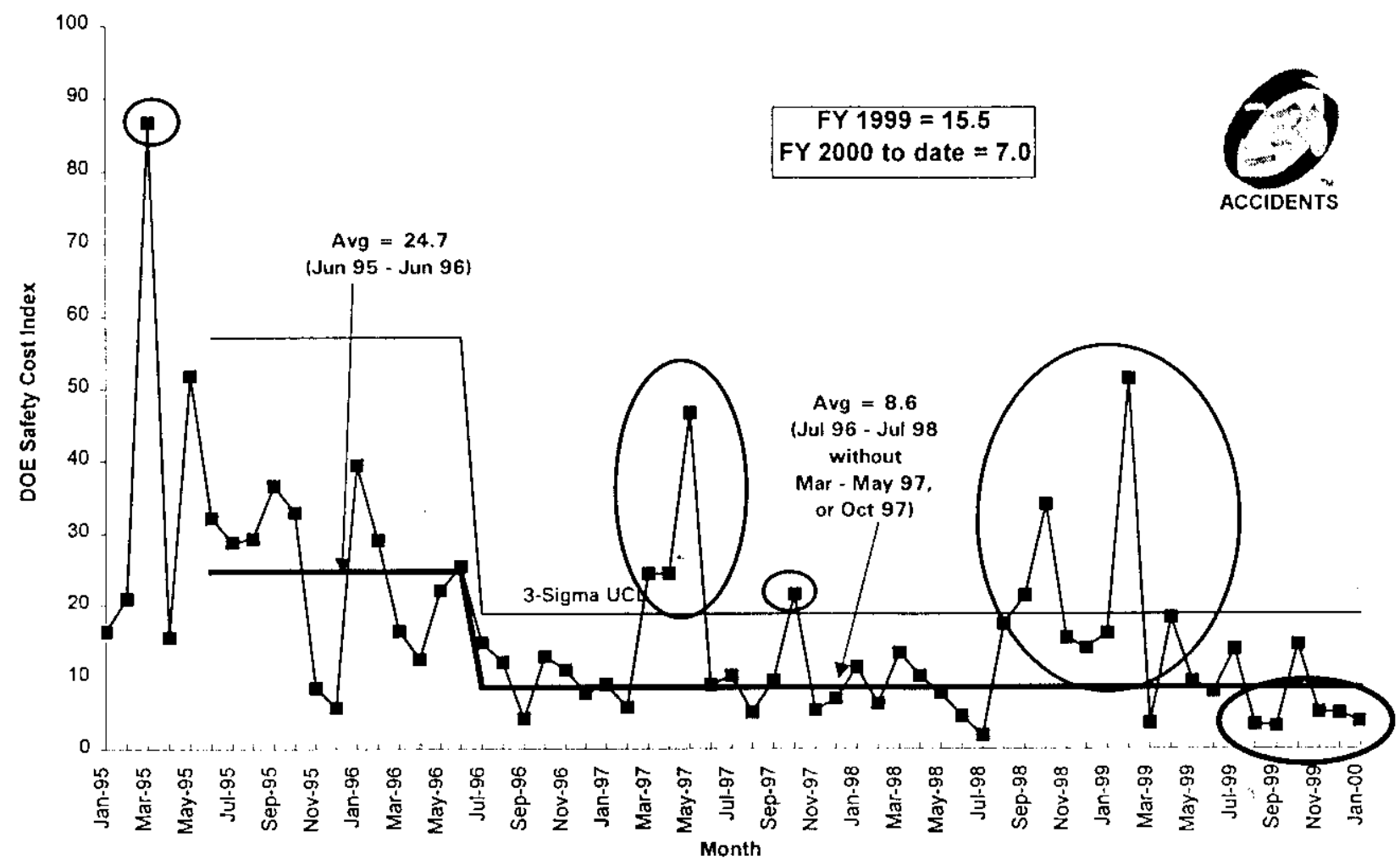

\section{Critical TeCHNiCAL ISSUES}

- 324 FACILITY BEHIND SCHEDULE

Downtime driven by equipment failure (A Cell crane) continues to create delays in the 324 Facility project schedules. The A Cell crane has been returned to limited service while procurement activities associated with repair are expedited. The implementation of the revised Project Management Plan has also resulted in some schedule recovery.

- CERTIFICATION OF HANFORD'S TRU PROJECT NECESSARY TO INITIATE WASTE SHIPMENT TO WIPP

The contractor continues working with the Carlsbad Area Office, the Environmental Protection Agency and the New Mexico Environment Department to achieve WIPP certification of Hanford's TRU Project. 


\section{KEY INTEGRATION ACTIVITIES}

$\mathrm{T}$ The following are the key technical integration activities that are currently underway and cross project/contractor lines. These activities are being addressed by inter-discipline and interproject groups and demonstrate that Hanford Site contractors are working together to accomplish the EM Clean up mission.

- Spent nuclear fuel (SNF) final disposition interface activities, including OCRWM QA Program implementation, ongoing with National SNF Program.

- 324 Building (B Cell) SNF removal acceptance criteria and conceptual design reviews ongoing with River Corridor Project.

- RCP Accelerated Deactivation Project personnel led a team comprised of workers from six Fluor Hanford organizations and three separate DOE contractors to complete the change out of B Plant's highly radioactive filters. This work, completed using innovative techniques and equipment was developed by this diverse work team, enhancing worker safety and productivity. This unparalleled cooperation and teamwork was recently recognized in a DOE surveillance which acknowledged the practices and processes used during this project met expectations by RL for "World Class" contractors performing work at Hanford.

- The DOE-HQ funded study of HLV Tank 105, located in the 324 Building is being conducted by AEA Technologies to demonstrate new technology in the deactivation of high dose radioactive tanks. The project technical plan, and implementation plan is completed while the draft of the alternatives assessment is on schedule for completion by April 2000.

- Continue working with PNNL on activities associated with the $\mathrm{Mg}(\mathrm{OH})_{2}$ process in order to accelerate the solution stabilization process, and polycube stabilization issues (gathering data for the SAR).

\section{Upcoming Planned Key Events}

$T$ he following Key events are extracted from the authorized baseline and are currently expected to be accomplished during the next three months. Most are EA, HQ or DNFSB Milestones.

\section{Waste Management:}

- MLLW Treatment -- Treat 1,160 cubic meters (includes 100 cubic meters stretch) of MLLW at ATG by August 2000; return Land Disposal Restriction compliant waste for disposal.

- Suspect TRU Waste Retrieval -- Retrieve 400 drums of suspect TRU waste from the LowLevel Burial Grounds by September 2000 (Stretch).

- K Basin Sludge -. Develop design requirements by September 2000 for acceptance of K Basin sludge at T Plant. 


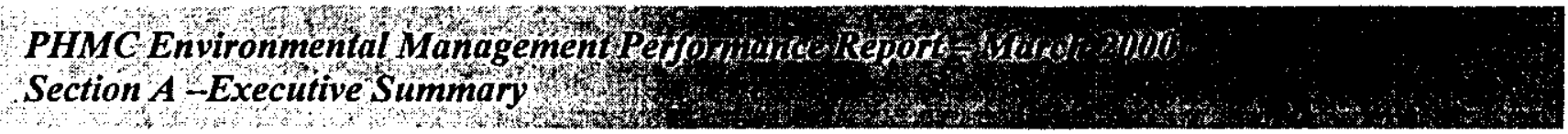

\section{Spent Nuclear Fuels:}

- Deliver first shipment of Multi-Canister Overpacks (MCOs) and baskets by June 1, 2000.

- Begin DOE Operational Readiness Review for fuel removal by mid September 2000. Begin K West Basin fuel removal, drying \& storage operations by November 30, 2000.

\section{River Corridor Project:}

- Complete all B Plant closeout activities by March 2000.

- Complete ISMS verification activities by May 15, 2000.

- Issue the final report for the 300 Area Waste Acid Treatment System (WATS) Resource Conservation and Recovery Act (RCRA) Closure Activities by September 2000.

- Complete Removal of 324 Building REC B Cell MW \& Equipment by November 2000

\section{Nuclear Materials Stabilization:}

- Complete furnace cool-down tests and implement new procedures.

- Begin Pu solution stabilization via $\mathrm{Mg}(\mathrm{OH})_{2}$ in FY 2000.

- Deliver glove boxes and equipment for installation by April 11, 2000.

- Complete ORR and training activities.

- Startup Cementation by April 21, 2000.

- Complete W-460 Facility Design by April 2000.

- Begin metal stabilization processing in November 2000. 

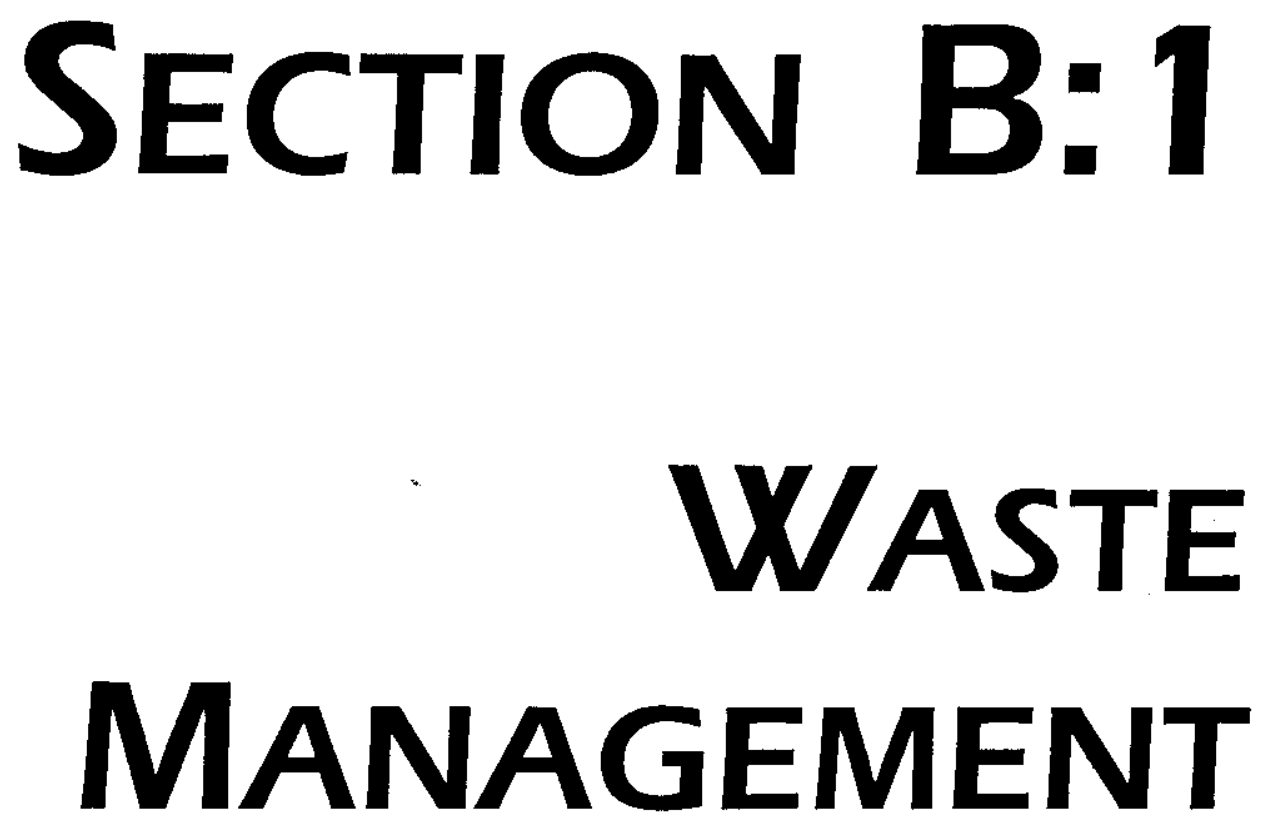

PROJECT MANAGERS

\author{
H. E. Bilson, RL \\ Phone: (509) 376-6628 \\ E. S. Aromi Jr., WMH \\ Phone: (509) 372-1033
}




\section{SUMMARY}

Waste Management consists of the Solid Waste Storage and Disposal, Project Baseline Summary (PBS) WM03, Work Breakdown Structure (WBS) 1.2.1; Solid Waste Treatment, PBS WM04, WBS 1.2.2; Liquid Effluents - 200 Area, PBS WM05, WBS 1.2.3.1; and the Waste Encapsulation and Storage Facility, PBS TP02, WBS 1.4.2.

NOTE: Unless otherwise noted, the Safety, Conduct of Operations, and Cost/Schedule Date contained herein is as of January 31, 2000. All other information is as of March 1, 2000.

The Carlsbad Area Office (CAO) audit of Hanford's Transuranic (TRU) Project to meet the requirements of the new Part B Waste Isolation Pilot Plant (WIPP) Resource Conservation and Recovery Act (RCRA) Permit was completed in January. Basic results are that the program is adequate and that implementation is satisfactory and effective. EPA is going to recommend qualification of the Hanford site TRU QA Program. Five Corrective Action Reports (CARs) resulted which are actively being worked with $\mathrm{CAO}$. An additional $\$ 2.5$ million of funding from CAO was received at Hanford for TRU shipment.

Shipped over 4,000 cubic feet (FYTD) of mixed low-level waste to ATG for non-thermal treatment. ATG completed four (4) macro-encapsulated waste containers to date, and preparations are on schedule to receive the first treated waste shipment into the Mixed Waste Disposal trenches in February.

Milestone performance (EA, DOE-HQ and RL) shows no milestones due this reporting period.

\section{ACCOMPLISHMENTS}

- $\quad$ Disposed 36,400 $\mathrm{ft}^{3}$ (FYTD) of Low Level Waste (LLW) in the burial grounds, as planned.

- $\quad$ Processed 1.9 million gallons (FYTD) of wastewater through the 200 Effluent Treatment Facility supporting River Protection Project (RPP), ERC 200-UP-1 Groundwater, NBasin Water, and ERDF Leachate, as planned.

- Completed nondestructive examination (NDE) on 257 drums, radiography on 8 boxes, non-destructive assays of 113 drums, processing of 10 drums through the repackaging/compaction glovebox, and visual examinations of 25 transuranic drums at the Waste Receiving and Processing (WRAP) facility, as planned as of March 1, 2000.

- $\quad$ Shipped over 166 cubic meters (FYTD) of mixed low-level waste (MLLW) to ATG, Inc. (ATG) for non-thermal threatment. ATG completed eleven (11) macro-encapsulated waste containers to date. Three (3) macro-encapsulated waste containers totaling over 8 cubic meters (FYTD) have been received and disposed into the Mixed Waste Disposal unit, and preparations are on schedule to receive an additional 21 cubic meters by February 24, 2000. 


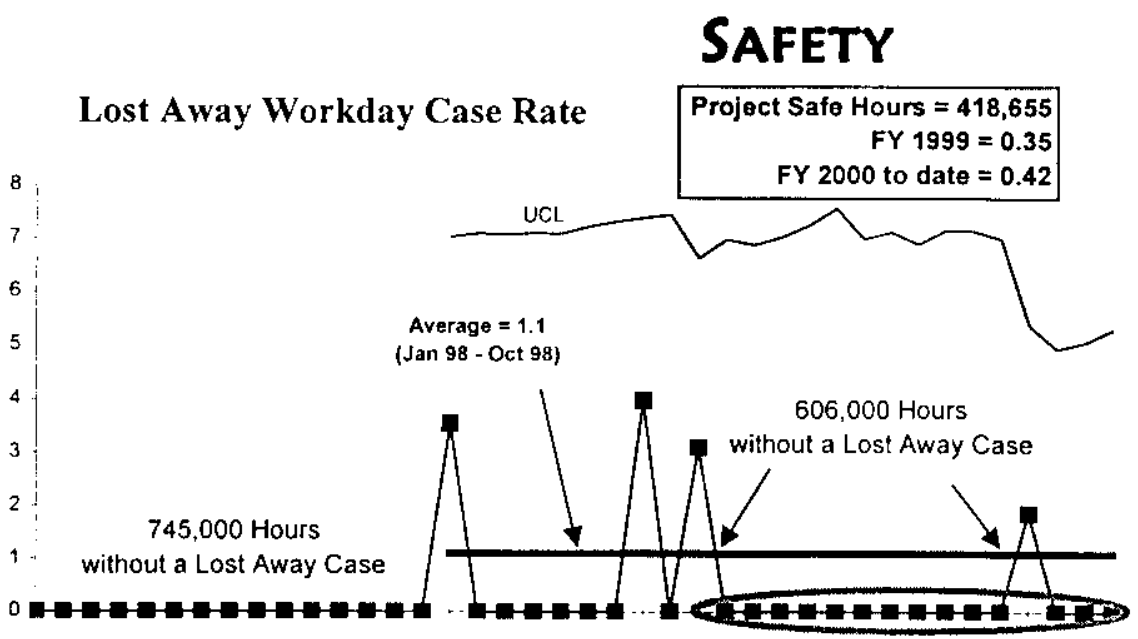

Fourteen of the past 15 months have been a zero, which is a positive trend.

Green

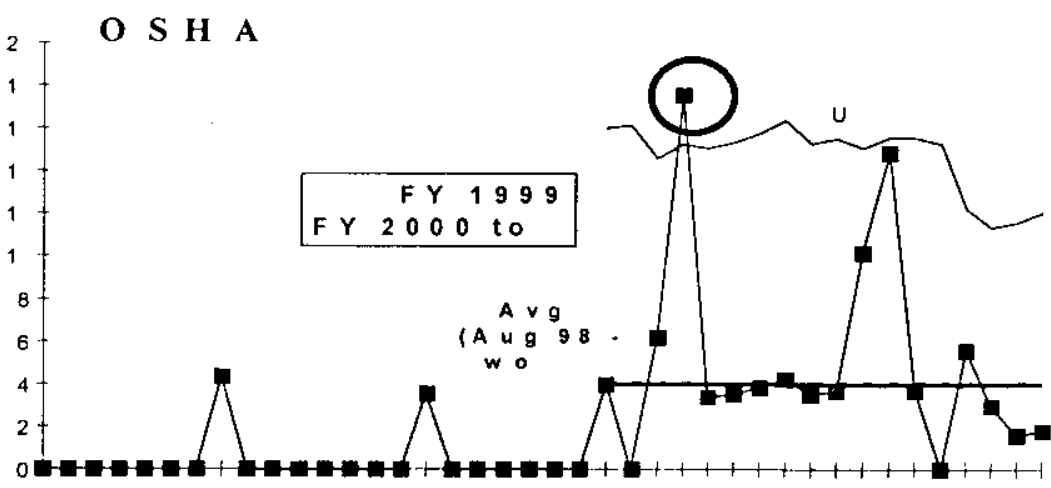

The past three months have been consistently below the baseline averages.

DOE Safety Cost Index

Yellow

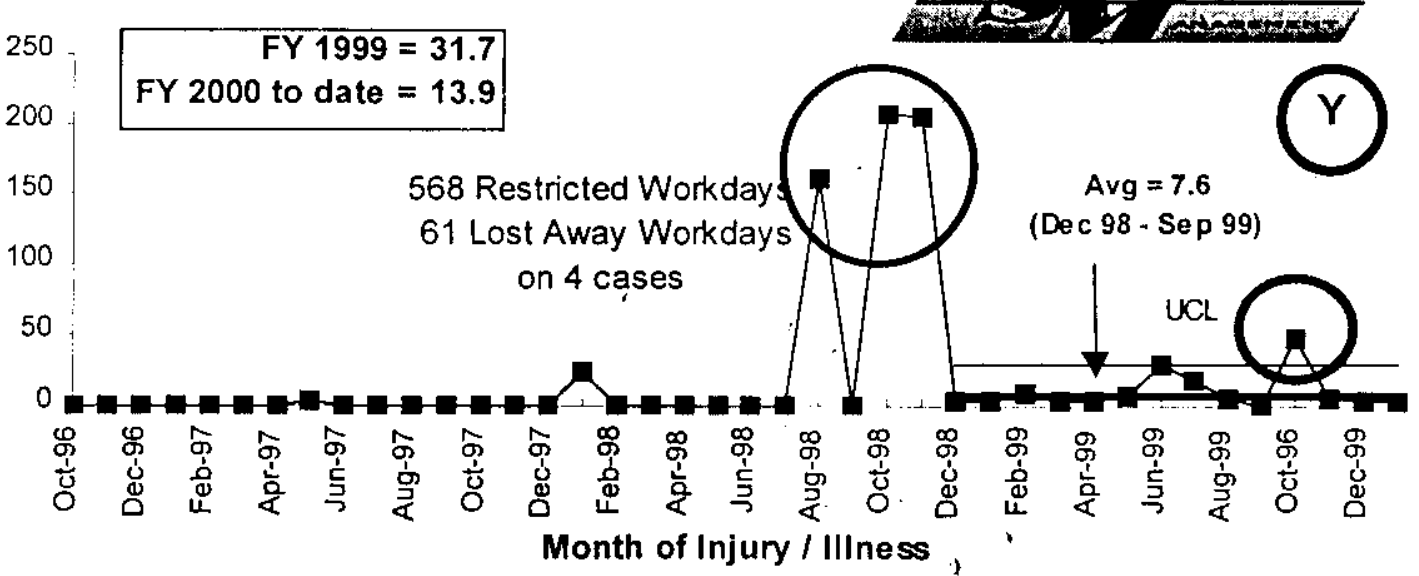

The past three months have been consistently below the baseline averages.

Yellow 


\section{CONDUCT OF OPERATIONS / ISMS STATUS}

\section{Conduct of Operations}

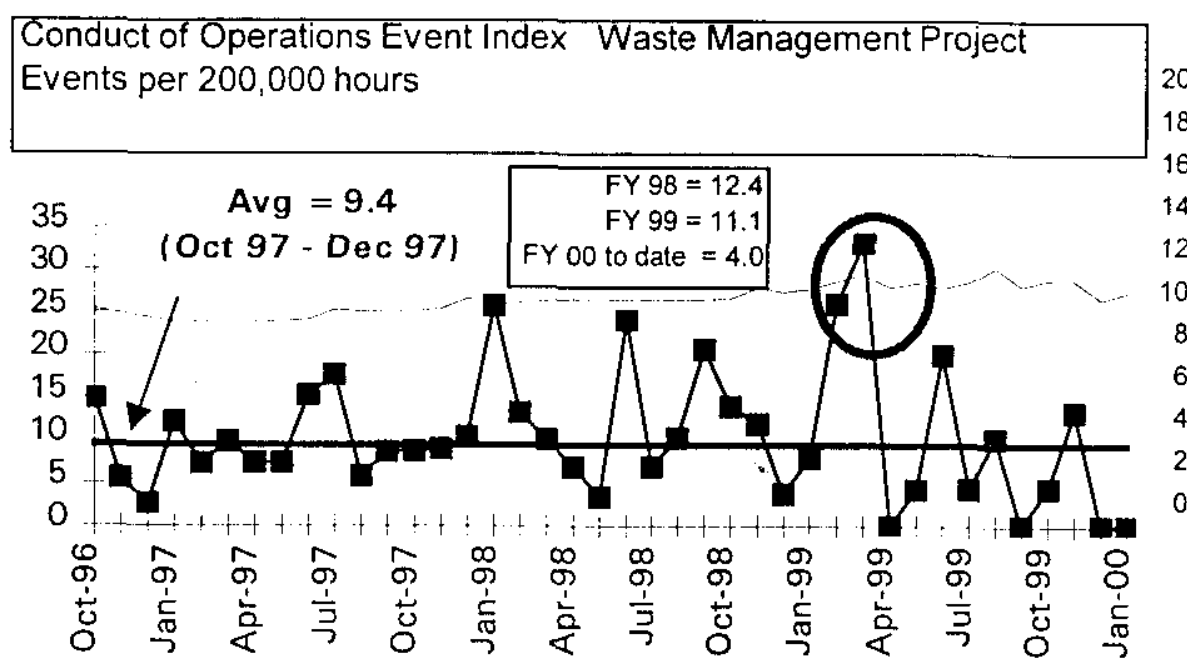

ISMS STATUS

No. of Reports

Past 12 Months

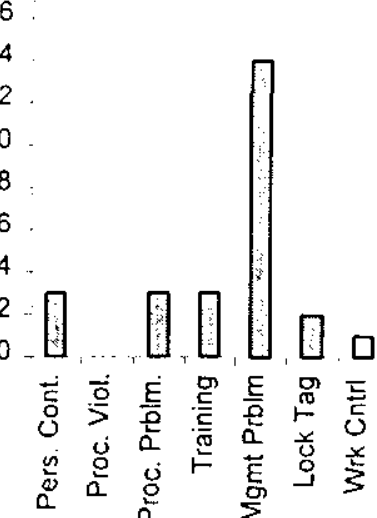

Green

\section{Completed activities:}

- $\quad$ Established a Waste Management Project/ Analytical Services (WMP/AS) core team in December 1999 to assure the accelerated ISMS integration schedule would be met

- Issued an integrated ISMS program plan in December 1999, setting a path to declaration of readiness

- $\quad$ Drafted systems descriptions of the integrated safety management systems for WMP and AS

- Identified policy and procedure gaps and initiated corrective actions

- Completed first session of ISMS training for all WMP and AS personnel

- Initiated self-assessments of readiness activities

Planned actions:

- Issue authorization agreements for Cat 2 nuclear facilities

- Complete self assessment of readiness activities

- Continue management system training

- Declare readiness on April 28, 2000 


\section{BREAKTHROUGHS / OPPORTUNITIES FOR IMPROVEMENT}

\section{Breakthroughs}

Nothing to report.

\section{Opportunities for Improvement}

Nothing to report.

\section{UPCOMING ACTIVITIES}

WIPP Certification and Waste Shipments -- Discussions are underway to obtain CAO support for the closure audit in the late March time frame. Complete WIPP Certification and initiate TRU shipments in the spring of 2000

242A Evaporator Operations-- Conduct 242- $\ddot{A}$ Evaporator Campaign beginning in April 2000

RH TRU PMP -- Issue Project Management Plan for RH TRU in June 2000 to meet M-91 milestone (Stretch)

MLLW Treatment -- Treat 1,160 cubic meters (includes 100 cubic meters stretch) of MLLW at ATG by August 2000; return Land Disposal Restriction compliant waste for disposal

Suspect TRU Waste Retrieval -- Retrieve 400 drums of suspect TRU waste from the Low-Level Burial Grounds by September 2000 (Stretch)

K Basin Sludge -- Develop design requirements by September 2000 for acceptance of K Basin sludge at T Plant

Accident Investigation Report -- Injured Effluent Treatment Facility employee returned to work on January 10,2000; the final accident investigation report will be issued in the 2nd Quarter of FY 2000

\section{Cost Performance $(\$ M)$ :}

\begin{tabular}{|l|c|c|c|}
\hline & BCWP & ACWP & VARIANCE \\
\hline Waste Management & $\$ 29.2$ & $\$ 28.6$ & $+\$ 0.6$ \\
\hline
\end{tabular}

The $\$ 0.6$ million (2 percent) favorable cost variance is within the established threshold. Further information at the PBS level can be found in the following Cost Variance Analysis details.

\section{Schedule Performance $(\$ M)$ :}

\begin{tabular}{|l|c|c|c|}
\hline & BCWP & BCWS & VARIANCE \\
\hline Waste Management & $\$ 29.2$ & $\$ 31.9$. & $-\$ 2.6$ \\
\hline
\end{tabular}

The $\$ 2.6$ million ( 8 percent) unfavorable schedule variance is primarily due to delays in TRU production and MLLW treatment. Further information at the PBS level can be found in the following Schedule Variance Analysis details. 


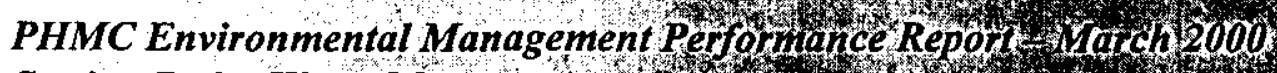

Section B: 1 - Waste Management

\section{FY 2000 Cost/Schedule Performance - All Fund Types \\ Cumulative to Date Status - $(\$ 000)$}

By PBS

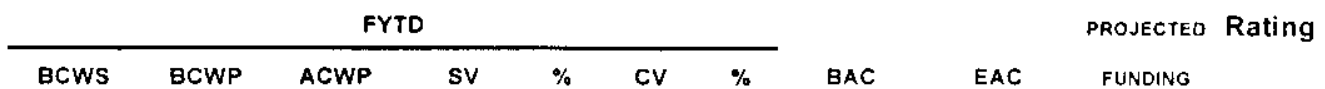

WM03 Solid Waste Storage \& Disposal

$\begin{array}{llllllllllllllllll}\$ & 11,021 & \$ & 10,843 & \$ & 10,106 & \$ & (178) & -2 \% & \$ & 737 & 7 \% & \$ & 36,028 & \$ & 32,719 & \$ & 33,119\end{array}$

WM04 Solid Waste Treatment

$\$ \quad 8,249$

WM05 Liquid Effluents

TPO2 WESF

\& 8.487 \& 7.868 \& 7.135 \& $(619) \quad-7 \%$ \& 733 \% \& 29.219 \& 27.807 \& 27.886

rotal

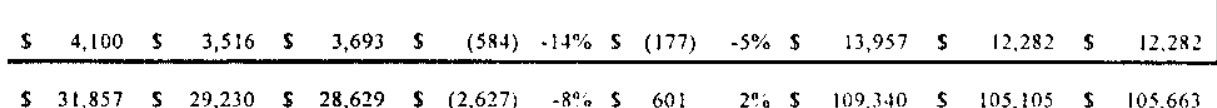

Green

Gris

\section{WBS - 1.2 / 1.4 .2 \\ Cost/Schedule Performance Indices \\ (JANUARY 2000 AND FYTD)}

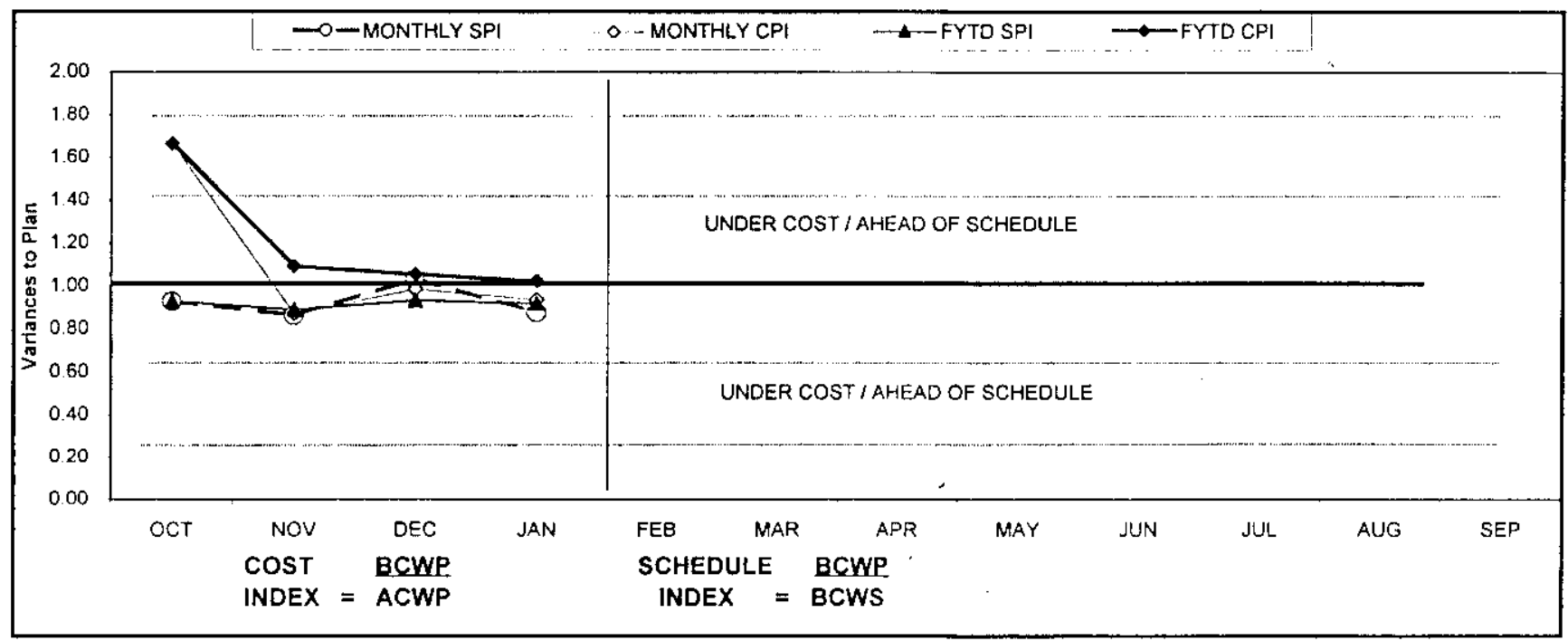

\begin{tabular}{|c|c|c|c|c|c|c|c|c|c|c|c|c|c|c|c|}
\hline FY 2000 & & DCT & & NOV & & DEC & JAN & FEB & MAR & APR & MAY & JUN & JUL & AUG & SEP \\
\hline MONTHLY CPI & & 1.66 & & 0.87 & & 0.98 & 0.94 & & & & & & & & \\
\hline FYTD SPI & & 0.93 & & 0.89 & & 0.93 & 0.92 & & & & & & & & \\
\hline FYTD CPI & & 1.66 & & 1.09 & & 1.05 & 1.02 & & & & & & & & \\
\hline MONTHLY BCWP & $\$$ & 6.163 & $\bar{s}$ & 8.277 & \$ & 7.499 & 7,291 & & & & & & & & \\
\hline MONTHLYY ACWP & $\$$ & 3,703 & $s$ & 9,518 & 5 & 7,619 & 7,789 & & & & & & & & \\
\hline FYTD BCWS & $\$$ & 6,641 & $\$$ & 16,257 & \$ & 23,526 & $\$ 31,857$ & & & & & & & & \\
\hline FYTD BCWP & $\$$ & 6.163 & $\$$ & 14,440 & $\mathbf{s}$ & 21,939 & $\$ 29,230$ & & & & & & & & \\
\hline
\end{tabular}

\section{ISSUES}

\section{Technical Issues}

None.

DOE/RL-99-83, Rev. 2 


\section{DOE/Regulator/External Issues}

The Waste Management Programmatic Environmental Impact Statement (PEIS) was issued on February 25, 2000. The Records of Decision (ROD) for LLW and MLLW will affect Hanford's disposal role for the Complex. The ROD outcomes may have a significant impact on disposal volumes and rates at Hanford.

Certification of Hanford's TRU Project is necessary to initiate waste shipment to WIPP. Continue working with the Carlsbad Area Office, the Environmental Protection Agency and the New Mexico Environment Department to achieve WIPP certification of Hanford's TRU Project.

\section{Cost Variance Analysis: $(+\$ 0.6)$}

\section{$\underline{\text { WBS } / P B S}$}

1.2.1/WM03

\section{Title}

Solid Waste Storage \& Disposal

Description/Cause: The favorable cost variance of $\$ 0.7 \mathrm{M}$ (7 percent) is within the established threshold.

Impact: No impact.

Corrective Action: No corrective action required.

\subsection{2/WM04}

Solid Waste Treatment

Description/Cause: The unfavorable cost variance of $-\$ 0.7 \mathrm{M}(-10$ percent $)$ is due to scope being performed under an Advanced Work Authorization (AWA) for T Plant support to accelerated SNF sludge removal. In addition, there are retooling costs caused by the new WIPP permit changes.

Impact: No impact.

Corrective Action: A BCR will be processed in March for both of these scopes of work.

\subsubsection{1/WM05 Liquid Effluents-200 Area}

Description/Cause: The favorable cost variance of $\$ 0.4 \mathrm{M}$ (6 percent) is within the established threshold.

Impact: No impact.

Corrective Action: No corrective action required.

\subsection{2/TP02 WESF}

Description/Cause: The unfavorable cost variance of $-\$ 0.2 \mathrm{M}(-5$ percent $)$ is caused by the UT testing and repair of the WESF stack.

Impact: No impact.

Corrective Action: The Carryover BCR will eliminate the UT,testing variance. The stack repair will be managed in the Corrective Maintenance budget. 


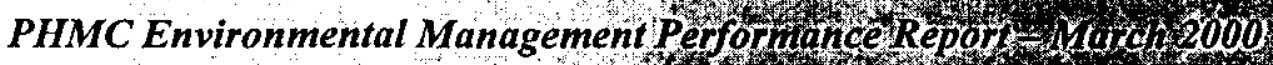

Section B: 1-Waste Management

\section{Schedule Variance Analysis: (- \$2.6)}

$\underline{\text { WBS/PBS }}$

\subsection{1/ WM03}

Solid Waste Storage \& Disposal

established threshold.

Impact: No Impact.

Corrective Action: No corrective action required.

\subsection{2/ WM04}

Solid Waste Treatment

Description /Cause: The unfavorable schedule variance of $-\$ 1.2 \mathrm{M}(-15 \%$ percent $)$ is due to the delay in TRU production and shipments, which is a result of WIPP permit changes and recertification. MLLW treatment is behind schedule due to ATG not completing construction on their facility as scheduled.

Impact: No Impact.

Corrective Action: ATG processing began in late December, 1999. The schedule will be recovered. TRU production is in the process of rebaselining to resolve WIPP certification audit comments and reworking the shipment schedule.

\subsubsection{1/ WM05}

\section{Liquid Effluents-200 Area}

Description /Cause: The unfavorable schedule variance of $-\$ 0.6 \mathrm{M}(-9 \%$ percent $)$ is due to ETF not operating as planned in January due to groundwater receipt ceasing.

Impact: No Impact.

Corrective Action: The production schedule is being evaluated to determine run scenarios and impacts for the remainder of the year.

\subsection{1/ TP02 WESF}

Description /Cause: The unfavorable schedule variance of $-\$ 0.6 \mathrm{M}(-14 \%$ percent $)$ is due to the deferral of the FSAR to FY 2002 to resolve DOE funding reductions.

Impact: No Impact.

Corrective Action: A BCR has been submitted to defer the FSAR.

\begin{tabular}{|c|c|c|c|c|c|c|c|c|c|}
\hline \multicolumn{10}{|c|}{ Baseline Change Requests Curreintly in Process } \\
\hline $\begin{array}{l}\text { PRONECT } \\
\text { CHANGE } \\
\text { NUMBER }\end{array}$ & $\begin{array}{l}\text { DATE } \\
\text { ORIGIN. }\end{array}$ & BCR TILE & $\begin{array}{l}\text { FYOO COST } \\
\text { IMPACT \$0O0 }\end{array}$ & $\mathrm{SCH}$ & TECH & $\begin{array}{c}\text { DATE TO } \\
\text { CCB }\end{array}$ & $\begin{array}{c}\text { CCB } \\
\text { APRVD }\end{array}$ & APRVD & $\begin{array}{l}\text { CURRENT } \\
\text { STATUS }\end{array}$ \\
\hline $\begin{array}{l}\text { WM-2000-002 } \\
\text { FSP-2000-007 } \\
\text { FSP-2000-018 } \\
\text { WM-2000-003 } \\
\text { WM-2000-004 }\end{array}$ & $\begin{array}{r}1 / 5 / 00 \\
12 / 2 / 99 \\
1 / 25 / 00 \\
2 / 8 / 00 \\
3 / 1 / 00 \\
\end{array}$ & $\begin{array}{l}\text { WMP FY } 00 \text { Mandated Funds Reduction } \\
\text { WESF Carryover } \\
\text { WESF FY } 00 \text { Mandated Funds Reduction } \\
\text { T-Plant Canyon CleanoffFuel removal } \\
\text { WM Suretch Goals }\end{array}$ & $\begin{array}{r}-\$ 3,042 \\
\$ 160 \\
-\$ 1,100 \\
\$ 3,952 \\
\$ 0\end{array}$ & & $\therefore$ & $\begin{array}{l}2 / 17 / 00 \\
1 / 14 / 00 \\
2 / 29 / 00 \\
1\end{array}$ & $\begin{array}{r}1 / 4 / 00 \\
2 / 29 / 00 \\
\end{array}$ & $2 / 11 / 00$ & $\begin{array}{l}\text { On Hold } \\
\text { Approved } \\
\text { At DOE-RL } \\
\text { In draft } \\
\text { In draft } \\
\end{array}$ \\
\hline \multicolumn{10}{|c|}{ ADVANCE WORK AUTTHORIZATIONS } \\
\hline $\begin{array}{l}\text { AWA } \\
\text { AWA }\end{array}$ & $\begin{array}{l}2 / 24 / 00 \\
2 / 25 / 00\end{array}$ & $\begin{array}{l}\text { T-Plant Canyon CleanoffFuel removal } \\
\text { TRU Retrieval }\end{array}$ & $\begin{array}{r}\$ 1,150 \\
\$ 165\end{array}$ & & & & & $\begin{array}{l}2 / 24 / 00 \\
2 / 25 / 00\end{array}$ & Scope Acoeleration \\
\hline
\end{tabular}




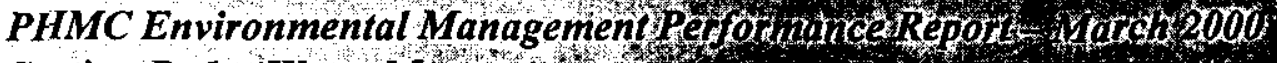

Section B: 1-Waste Management

\section{WASTe MANAGEMENT - WBS 1.2 MILESTONE ACHIEVEMENT}

\begin{tabular}{|c|c|c|c|c|c|c|c|c|}
\hline \multirow[b]{2}{*}{ MILESTONE TYPE } & \multicolumn{4}{|c|}{ FISCAL YEAR-TO-DATE } & \multicolumn{3}{|c|}{ REMAINING SCHEDULED } & \multirow[b]{2}{*}{$\begin{array}{c}\text { TOTAL } \\
\text { FY } 2000\end{array}$} \\
\hline & $\begin{array}{c}\text { Completed } \\
\text { Eariy }\end{array}$ & $\begin{array}{c}\text { Completed } \\
\text { On Schedule }\end{array}$ & $\begin{array}{c}\text { Completed } \\
\text { Late }\end{array}$ & Overdue & $\begin{array}{l}\text { Forecast } \\
\text { Early }\end{array}$ & $\begin{array}{c}\text { Forecast On } \\
\text { Schedule }\end{array}$ & Forecast Late & \\
\hline Enforceable Agreement & 0 & 0 & 0 & 0 & 0 & 2 & 0 & 2 \\
\hline DOE-HQ & 0 & 0 & 0 & 0 & 0 & 0 & 0 & 0 \\
\hline $\mathrm{RL}$ & 0 & 0 & 0 & 0 & 0 & 9 & 0 & 9 \\
\hline Total Project & 0 & 0 & 0 & 0 & 0 & 11 & 0 & 11 \\
\hline
\end{tabular}

\section{Tri-Party Agreement / EA Milestones}

M-91-03 (WMH-00-001, "Issue TRU/TRUM Waste PMP", due 06/30/00 - On schedule (stretch)

M-91-04 (A2J-00-001), "Complete Construction of CH TRU/TRUM Retrieval Facility", due 09/29/00 - Submitted letter to RL on October 28, 1999 documenting that retrieval was initiated and will proceed without construction of Project $W-113$ facilities. Recommended to RL to notify EPA and Ecology of the completion of interim milestone M-91-04 and to discuss M-91-07 issues.

Green

Nothing to report

\section{MILESTONE EXCEPTION REPORT}

\begin{tabular}{|c|c|}
\hline Number/WBS Level & Milestone Title \\
\hline
\end{tabular}

\section{OVerdue - 0 \\ FORECAST LATE - 0}

\section{FY 1999 OVERDUE - 1}

TRP-98-709 RL

1.4 .2
Complete Hot Cell Deactivation

WESF Facility (A-E)
$03 / 31 / 99 \quad 06 / 30 / 00$

Cause: This milestone is not complete due to not being supported at the current funding level. Impact: No overall impact is expected.

Corrective Action: Awaiting determination of funding source. 


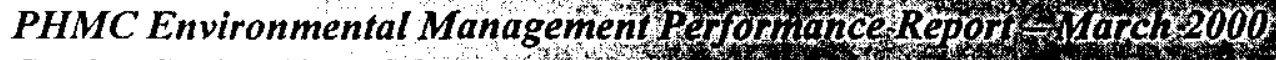

Section B: 1-Waste Management

\section{Performance Objectives \\ MLLW Treatment}

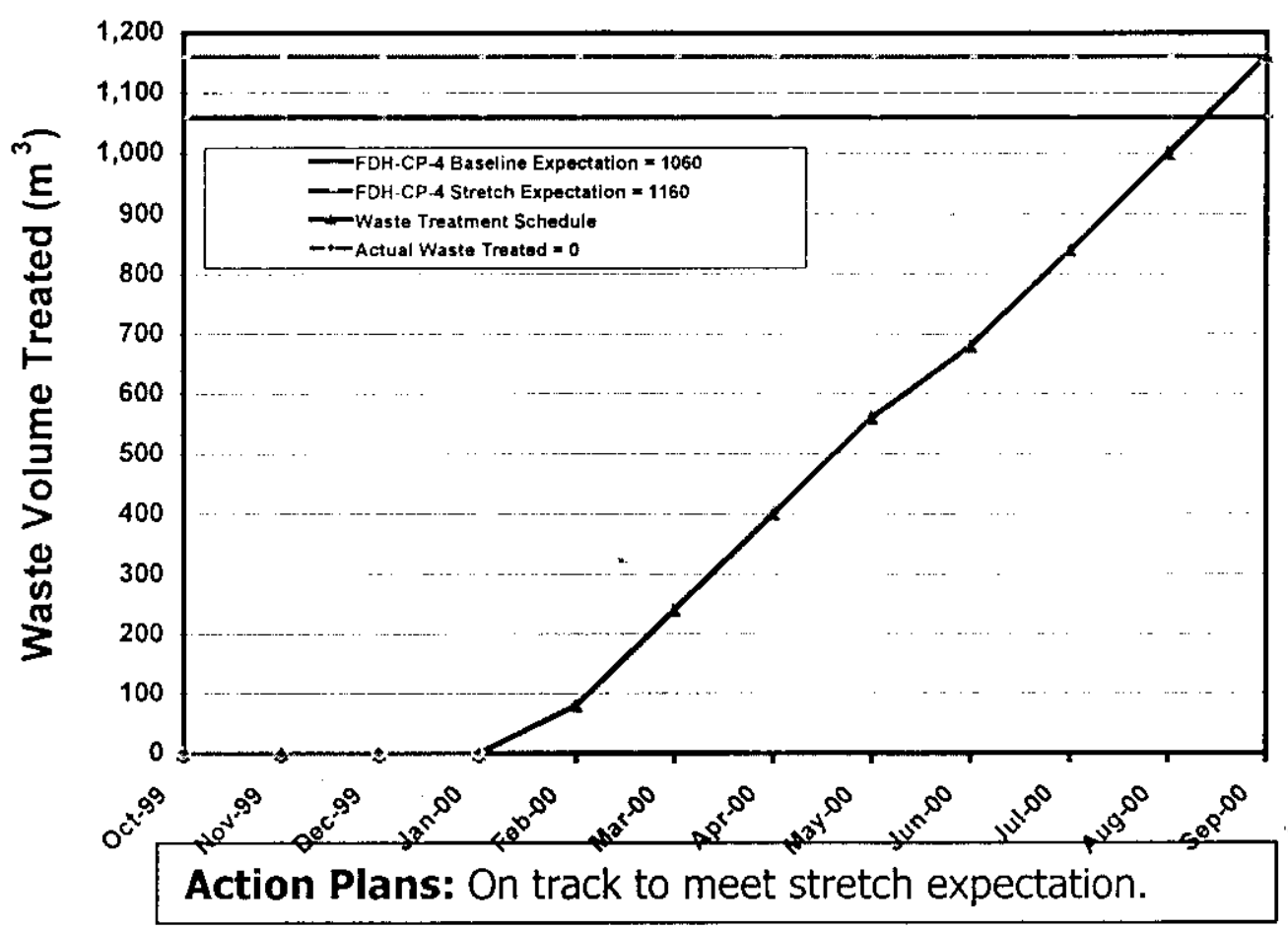

MLLW Disposal

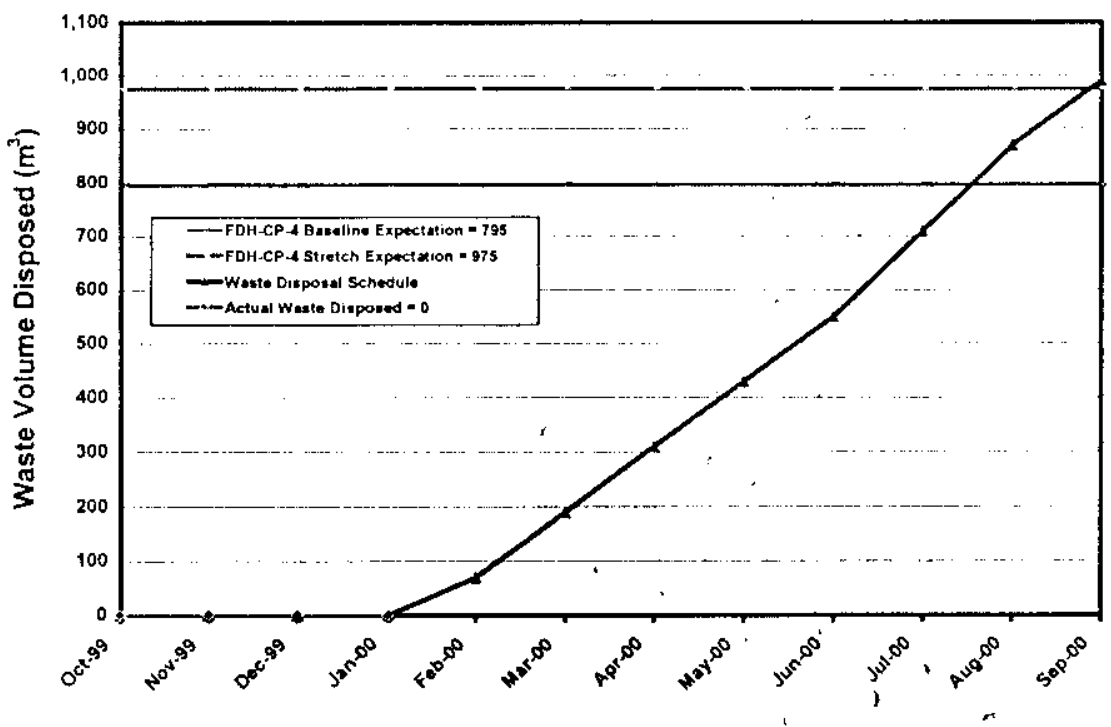

Green

Action Plans: On track to meet stretch expectation. 


\section{TRU Retrieval}
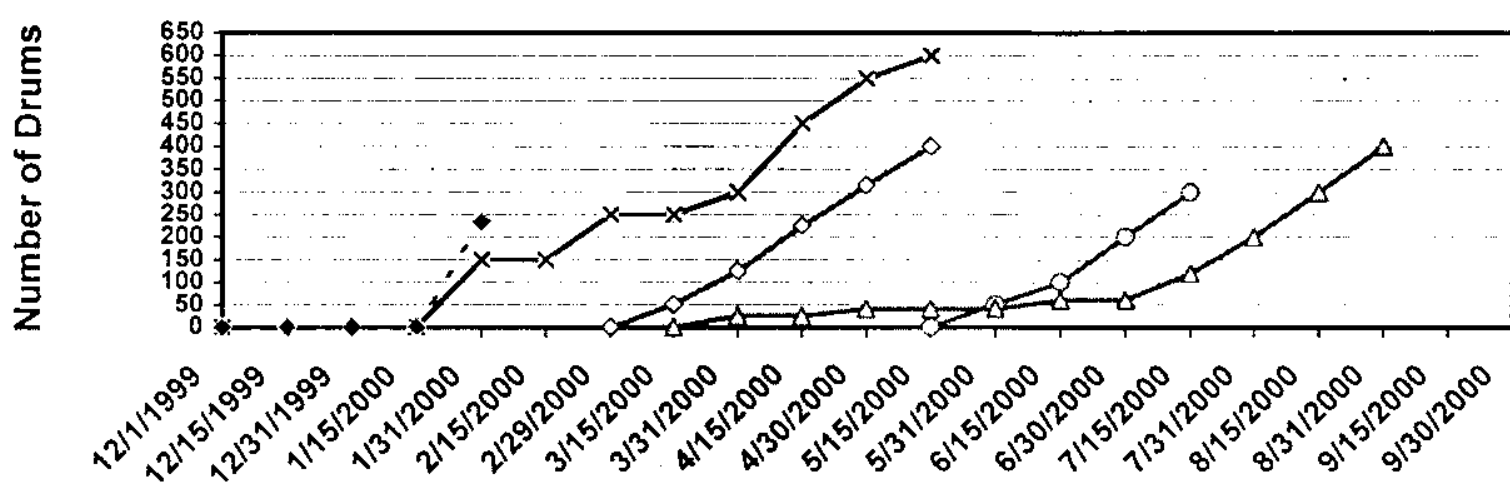

\begin{tabular}{|c|c|}
\hline $\begin{array}{l}-x-\text { Record Review }- \text { Plan }=150 \\
- \text { Drum Removal \& Staging - Plan }=0 \\
- \text { Field Assay - Plan }=0 \\
- \text { Assign Waste Designation }- \text { Plan }=0\end{array}$ & $\begin{array}{l}=- \text { - Record Review - Actual }=234 \\
=- \text { - Drum Removal \& Staging - Actual }=0 \\
-\quad \text { - Field Assay - Actual }=0 \\
-* \text { - Assign Waste Designation - Actual }=0\end{array}$ \\
\hline
\end{tabular}

Action Plans: On track. Completed 234 document reviews in January. Field retrieval activities planned to start in March with planned completion in mid-May.

\section{TRU Container Processing}

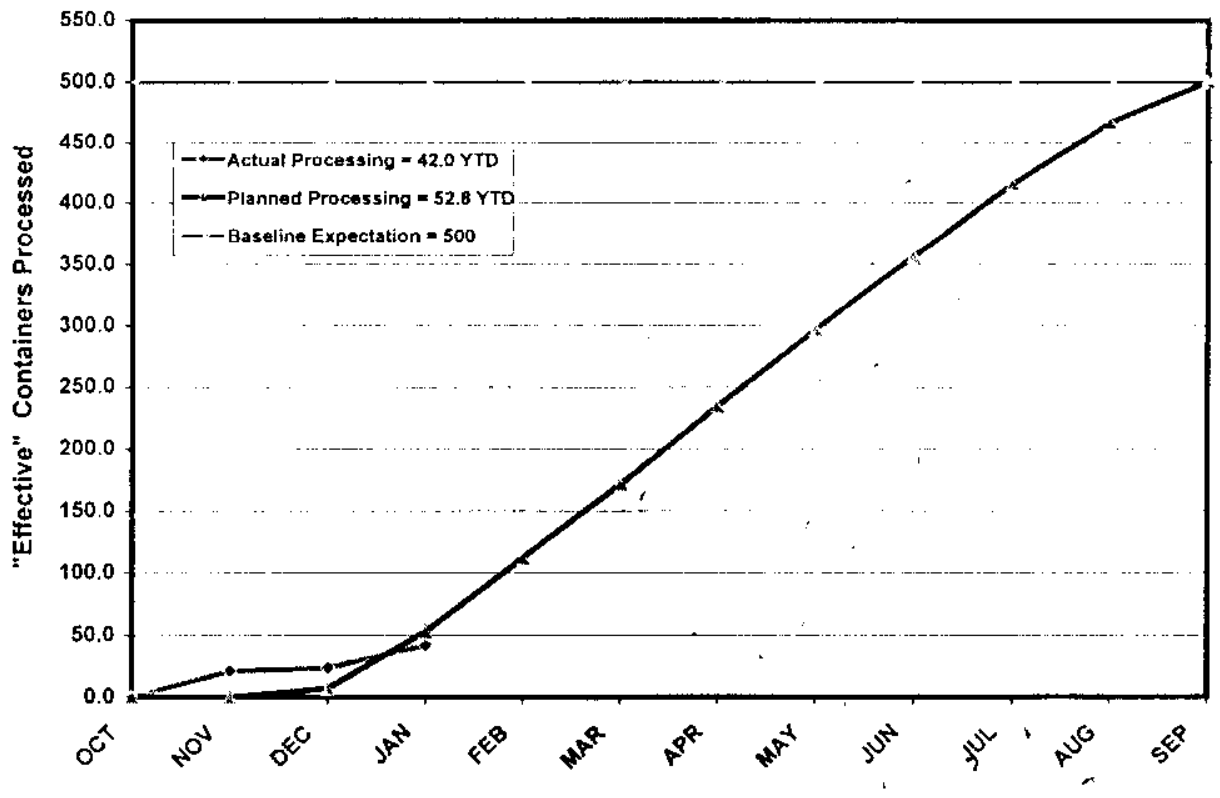

Action Plans: On track to meet the baseline expectation. 


\section{TRU Shipments}

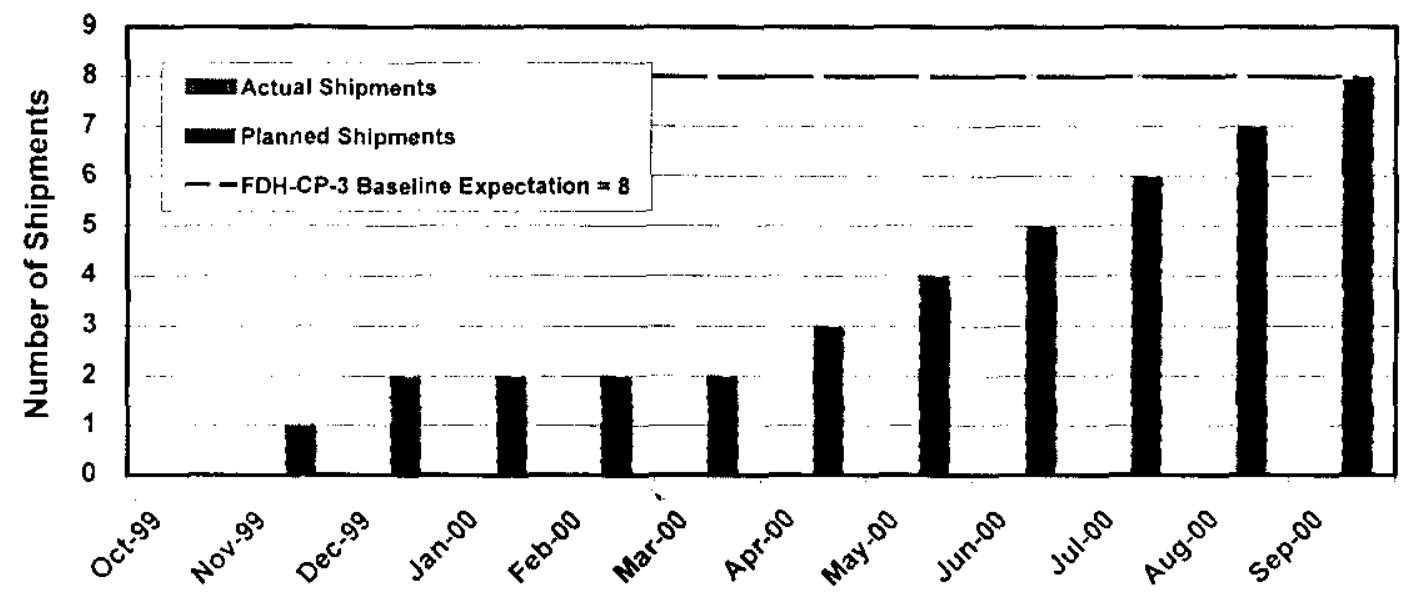

Action Plans: Change/Negotiation required based on pending CAO WIPP Certification audit results. Initial shipment delayed until spring 2000.

\section{Liquid Waste Processing}

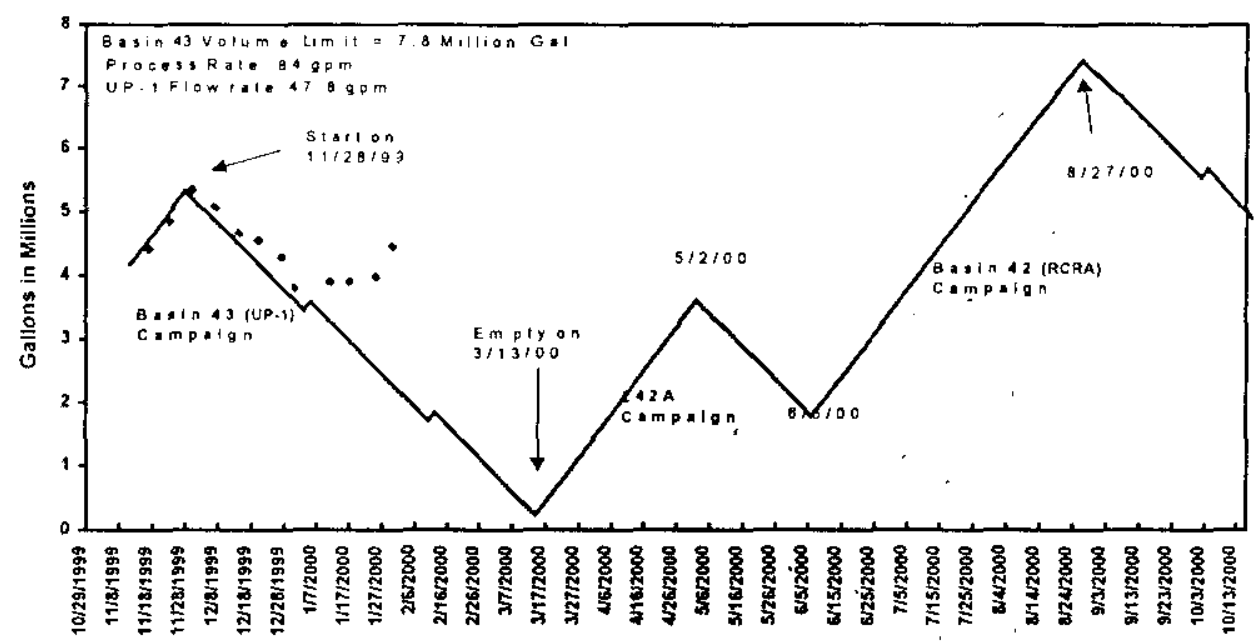

\section{-Basellng $\rightarrow A \in t u a I$}

Action Plans: BHI shut down 200-UP-1 groundwater on 12/27/99 and restarted on $1 / 26 / 00$. Plant was shut down during January for maintenance and will start up to work the 200-UP-1 inventory back down. 


\section{Key INTEGRATION ACTIVITIES}

- $\quad$ Representatives from DOE- RL, -Oakland, and -Ohio met at Hanford to discuss inter-site transfer of TRU waste from three DOE small quantity site generators and to develop preliminary plans for disposition of these wastes

- Develop design requirements by September 2000 for acceptance of K Basin sludge at T Plant

- $\quad$ Support River Corridor Project in cleanup and removal of waste from 324 and 327 buildings

- Issuance of Records of Decision for LLW and MLLW is expected to affect Hanford's role in disposing of waste from other sites. DOE's preferred alternative for LLW and MLLW disposal is to establish regional LLW disposal and MLLW disposal operations at two DOE sites; Hanford and NTS

- $\quad$ Support DOE-RL declaration of Readiness-to-Proceed in support of the ORP Privatization contract, specifically in the areas of liquid effluent and solid waste

- $\quad$ Support BHI by treating 200-UP-1 groundwater and ERDF leachate at the 200 Area ETF 

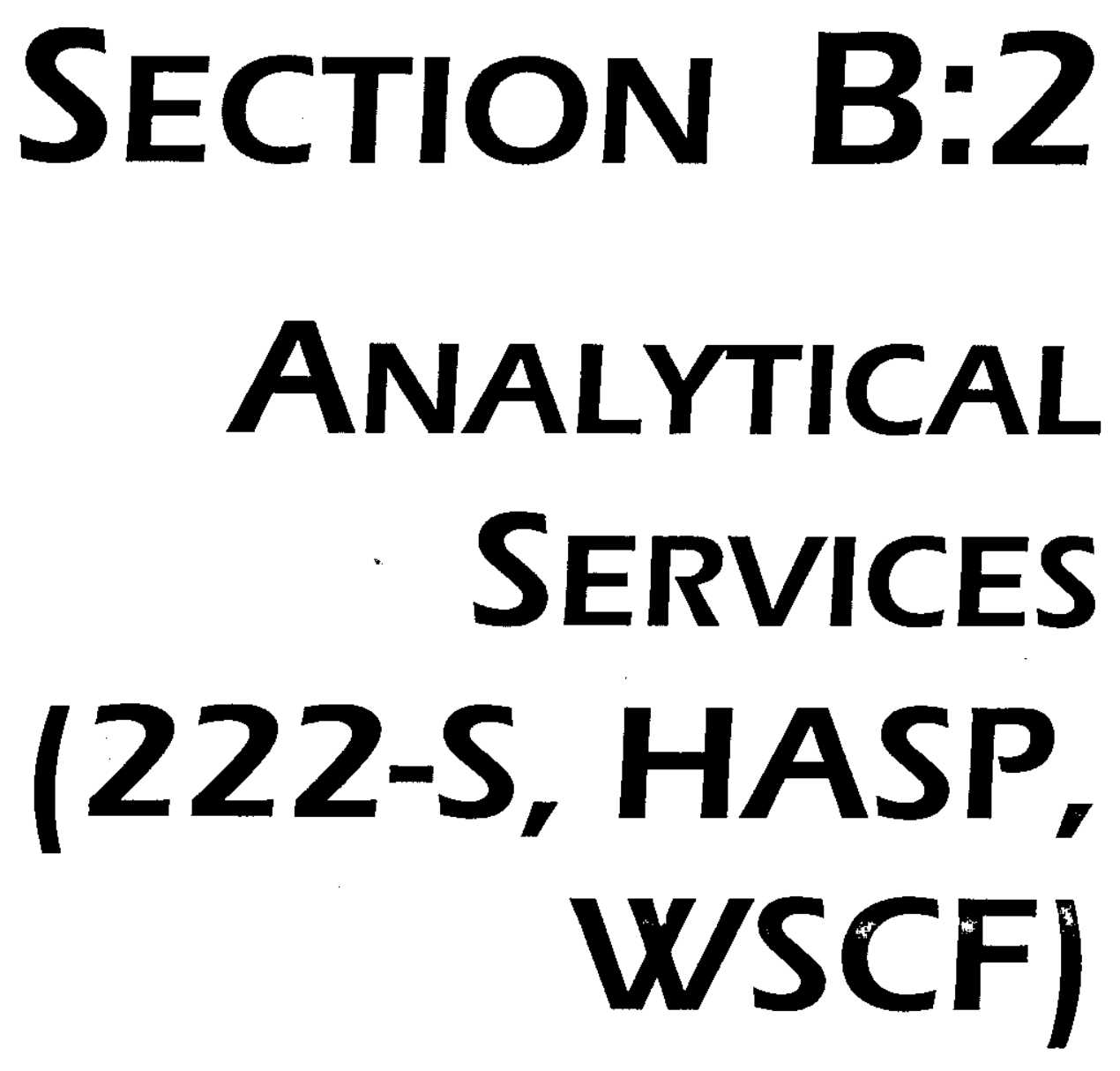

PROJECT MANAGERS

S. H. Wisness, RL

Phone: (509) 373-9337

D.L.'. Renberger, FH
Phone: (509) 372-0877 


\section{SUMMARY}

Analytical Services [222-S, Hanford Analytical Services Program (HASP), Waste Sampling and Characterization Facility (WSCF)] consists of Analytical Services, PBS WM06, WBS 1.2.4.

NOTE: Unless otherwise noted, the Safety, Conduct of Operations, and Cost/Schedule data contained herein is as of January 31,2000. All other information is as of March 10, 2000.

Preparations were conducted for headspace gas sampling and analysis of 5 TRU waste containers planned for early January 2000. A case narrative was built to validate the adequacy of the previously analyzed 107 drums. The data report will support the January 24, 2000 Carlsbad Area Office audit of Hanford's TRU Program WIPP certification. Technical issues related to Field Reference Standard Certification of Summa Canister Assemblies (SCA) have been successfully resolved.

Milestone performance (EA, DOE-HQ and RL) shows no milestones are due this reporting period.

\section{ACCOMPLISHMENTS}

- $\quad$ Performed 1.9 Analytical Equivalency Units (AEU) (FYTD) through January 2000 at the 222-S Laboratory in support of the RPP (TWRS) tank characterization program as planned. Received six segments from AY-101, 10 grab samples from AP-101, and completed extrusions of six AY-101 segments, all as planned. Completed grab sample analysis on SY-102 and AP-108 on schedule. Analytical output lagged in the first four months due to failed hot cell manipulators and a shortage of health physics technicians. However, February and March output has been high and the shortfall will be eliminated by the end of the month. A total of 4.0 AEUs have been processed through March 3, 2000 .

- $\quad$ Procedures, methods, equipment, and training all had to be significantly revised to meet the new WIPP permit from the State of New Mexico. All these changes had to be done rapidly to meet overall project audit and shipment schedules. Performed 3,000 analyses (FYTD) through January 2000 at WSCF for a wide variety of customers as planned.

- $\quad$ Completed the Facility Evaluation Board audit at the 222-S and WSCF laboratories in January 2000. The final FEB report was issued in February 2000 with improvements in 9 of 10 areas and an overall rating of " 3 ".

\section{SAFETY}

Notes: Although a small organization (meaning a single case gives a high case per hour figure), the three recent (April, November and December 1999) Lost Away Workday cases should be examined closely as they do reflect a significant increase over previous history. The AS Lost Workday Case Rate is significantly higher than the PHMC average. There is a significant increase in the Lost/Restricted Workday Case Rate for Nov 99 - Jan 00.

OSHA recordable case rate and DOE Safety Cost Index have been chosen by DOE HQ as ISMS performance indicators, reference T J GLAUTHIER memorandum of December 3, 1999. 


\section{Analytical Services}

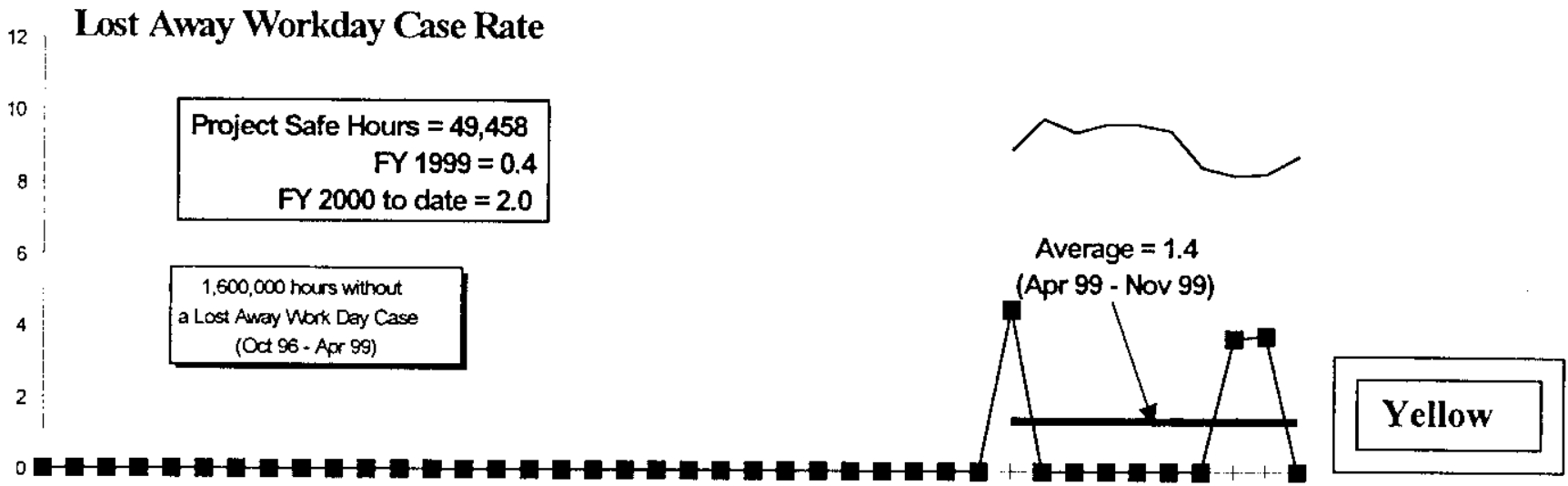

The two lost away case in FY 2000 were a result of an employee falling from a chair and a knee abrasion that progressed to complications despite continued attention from medical providers.

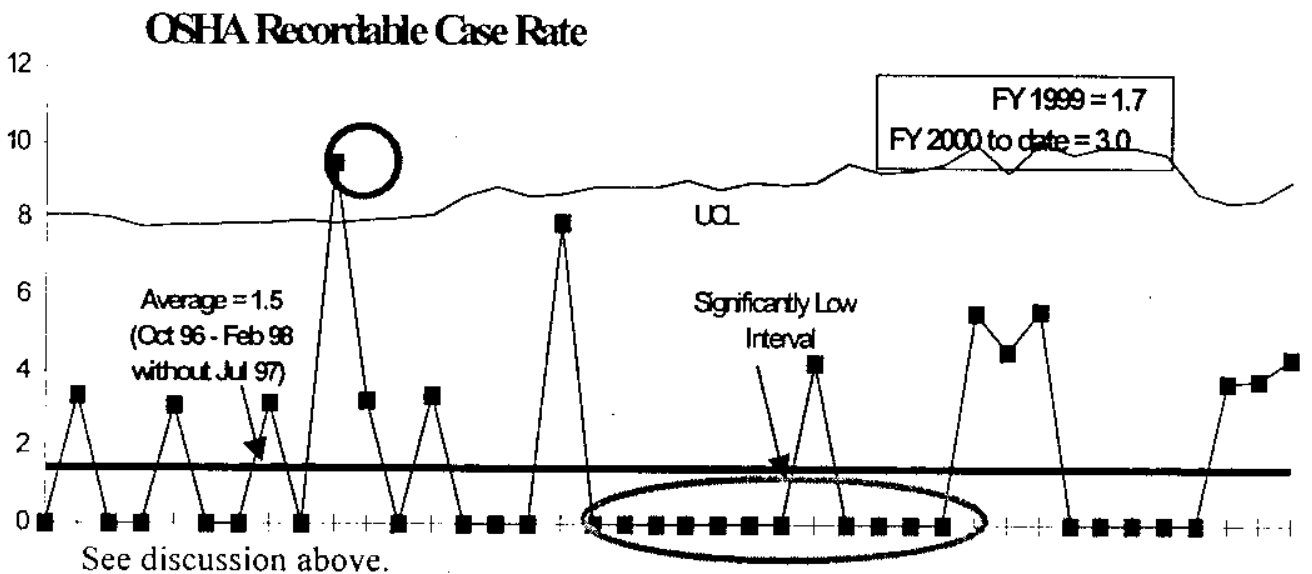

Yellow

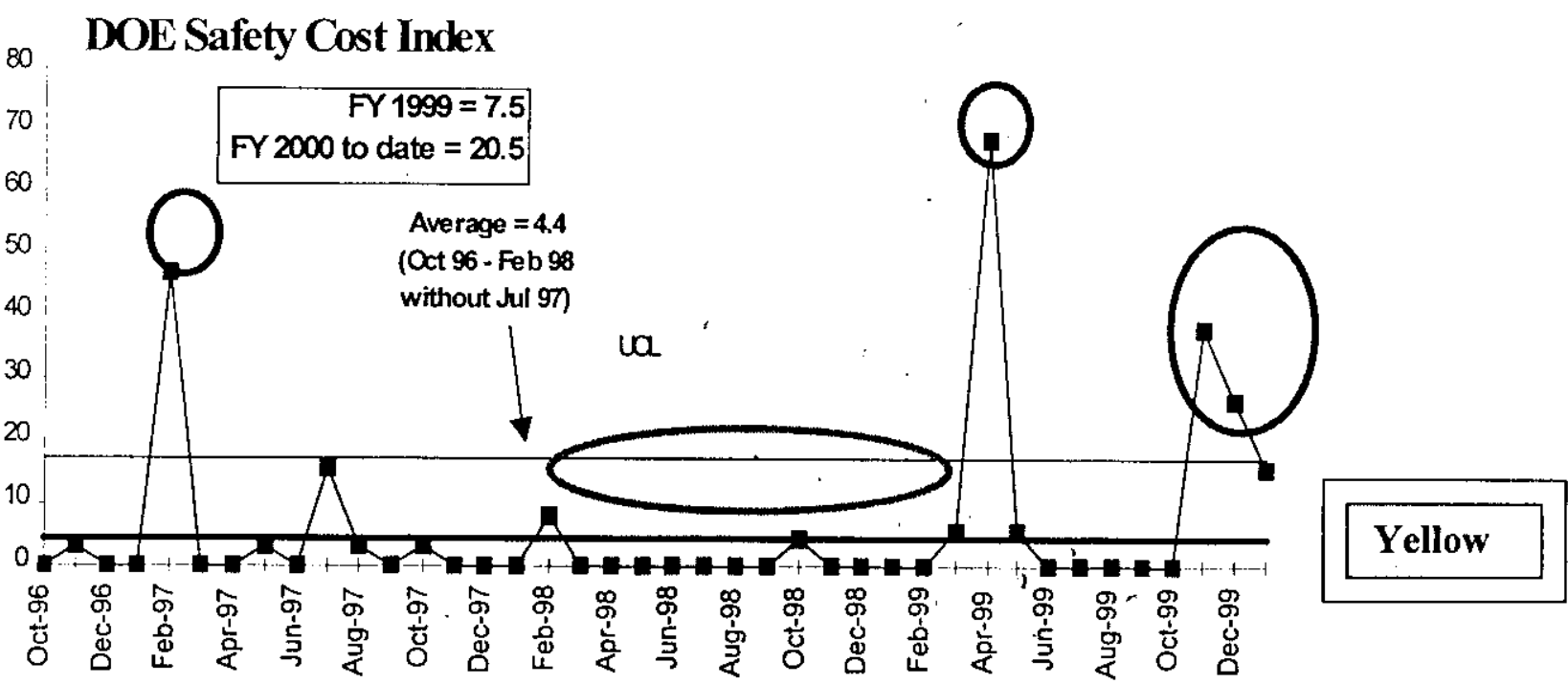

All employee stand-down meetings were held at 222-S January 14, 2000 to refocus on safety and personal and team accountability. 


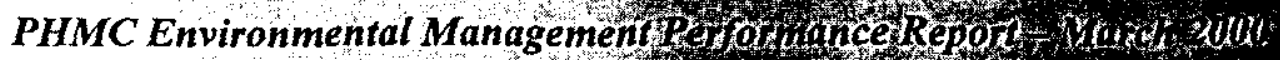

Section B: 2 -Analytical Services $(22,8$, if SP WSG

\section{CONDUCT OF OPERATIONS / ISMS Status CONDUCT OF OPERATIONS}

Analytical Services Conduct of Operations is included in the Waste Management Project Section of this report.

\section{ISMS STATUS}

\section{Completed activities:}

- Established a Waste Management Project/Analytical Services (WMP/AS) core team in December 1999 to assure the accelerated ISMS integration schedule would be met

- Drafted systems descriptions of the integrated management systems for WMP and AS

- Completed first session of ISMS training for all WMP and AS personnel

Planned actions:

- Issue authorization agreements for Cat 2 nuclear facilities 


\section{BREAKTHROUGHS / OPPORTUNITIES FOR IMPROVEMENT}

\section{Breakthroughs}

Nothing to report.

\section{Opportunities for Improvement}

Nothing to report.

\section{UPCOMING ACTIVITIES}

WIPP Certification and Waste Shipments -- Discussions are underway to obtain CAO support for the closure audit in the late March time frame. Complete WIPP Certification and initiate TRU shipments in the spring of 2000. Staff is expediting analytical work and data reports to provide additional qualified drums for shipment to WIPP. Potential issues with some prior sampled drums make this a necessity.

242A Evaporator Operations - Due to inadequate feed material from tank farms, expedited analysis of a second tank is being done to support the planned April 2000 campaign.

ORP Readiness to Proceed -- It has been determined that Analytical Services is prepared to support the readiness to proceed decision for the BNFL contract. Key follow-up actions are:

- $\quad$ Formal specification of requirements from ORP to RL and then to FH

- Stable funding of needed equipment and facility repair in Multi-Year Work Plans (RL and ORP)

- Funding replacement of obsolete laboratory support systems (Information Management)

- Funding of staff to maintain core competency

Laboratory FEB -- Support the FEB issuance of the final report and address applicable findings and observations

\section{Cost Performance (\$M):}

\begin{tabular}{|l|c|c|c|}
\hline & BCWP & ACWP & VARIANCE \\
\hline Analytical Services & $\$ 8.7$ & $\$ 8.8$ & $-\$ 0.1$ \\
\hline
\end{tabular}

The $\$ 0.1$ million (1.1 percent) unfavorable cost variance is within the established threshold. 
PHMC Environmental Management Pefornance Repoy 7 Harch 2000

Section B: 2 -Analytical Services (222, S, HSP,WSCH)

\section{Schedule Performance (\$M):}

\begin{tabular}{|l|c|c|c|}
\hline & BCWP & BCWS & VARIANCE \\
\hline Analytical Services & $\$ 8.7$ & $\$ 8.8$ & $-\$ 0.1$ \\
\hline
\end{tabular}

The $\$ 0.1$ million (1.5 percent) unfavorable schedule variance is within the established threshold.

ANALYTICAL SERVICES Status

WBS 1.24

\begin{tabular}{|c|c|c|c|c|c|c|c|c|c|c|c|c|}
\hline \multicolumn{13}{|c|}{$\begin{array}{r}\text { FY } 2000 \text { Cost/Schedule Performance - All Fur } \\
\text { Cumulative to Date Status - }(\$ 000)\end{array}$} \\
\hline \multirow{2}{*}{\multicolumn{2}{|c|}{ By PBS }} & \multicolumn{7}{|c|}{ FYTD } & \multirow[b]{2}{*}{ BAC } & \multirow[b]{2}{*}{ EAC } & \multirow{2}{*}{$\begin{array}{l}\text { PROJECTED } \\
\text { FUNDING }\end{array}$} & \multirow[t]{2}{*}{ Rating } \\
\hline & & BCWs & BCWP & ACWP & sv & $\%$ & $\mathrm{cv}$ & $\%$ & & & & \\
\hline \multirow[t]{2}{*}{ WM06 } & Analytical Services & 8797 & 8662 & 8765 & -135 & $-1.5 \%$ & -103 & $-1.2 \%$ & 27,281 & 28,473 & 26,618 & 2 \\
\hline & Total & 8797 & 8662 & 8765 & -135 & $-1.5 \%$ & -103 & $-1.2 \%$ & 27,281 & 28,473 & 26618 & \\
\hline
\end{tabular}

\section{Cost/Schedule Performance Indices (JANUARY 2000 AND FYTD)}

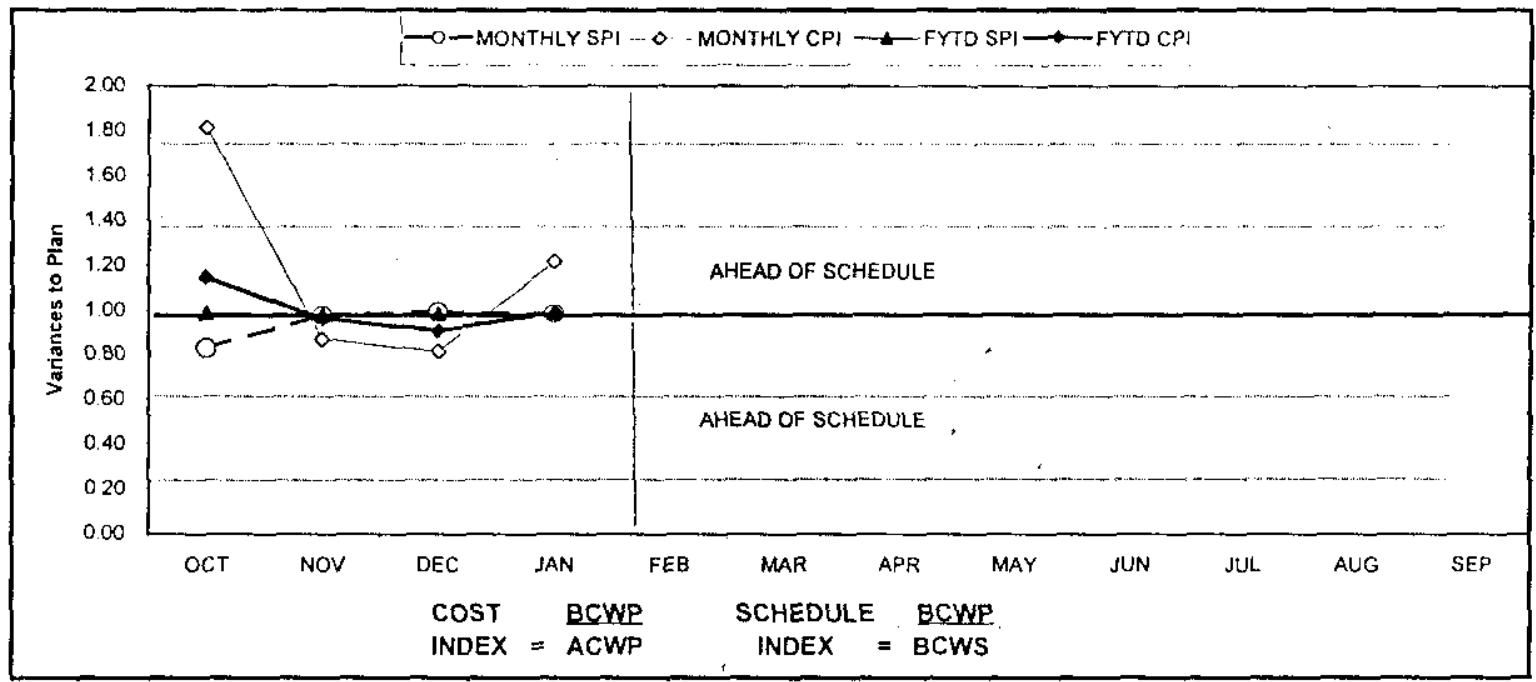

\begin{tabular}{|c|c|c|c|c|c|c|c|c|c|c|c|c|}
\hline FY 2000 & OCT & NOV & DEC & JAN & FEB & MAR & APR & MAY & JUN & JUL & AUGG & SEP \\
\hline MONTHLY SPI & 0.83 & 0.98 & 0.99 & 0.98 & & & & & & & & \\
\hline MONTHLYCPI & 181 & 0.87 & 081 & 1.22 & & & & & & & & \\
\hline FYTD SPI & 0.90 & 0.98 & 0.99 & 0.98 & & & & & & & & \\
\hline FYTD CPI & 1.14 & 0.96 & 0.91 & 0.99 & & $\because$ & & & & & & \\
\hline MONTHLY BCWS & $\$ 7,913$ & $\$ 2,340$ & $\$ 1,973$ & $\$ 2,896$ & & & & & & & & \\
\hline MONTHLY BCWP & $\$ 6,543$ & $\$ 2,280$ & $\$ \$, 961$ & $\$ 2,847$ & & & & & & & & \\
\hline MONTHLY ACWP & $\$ 3,613$ & $\$ 2,640$ & $\$ 2,414$ & $\$ 2,342$ & & & & & & & & \\
\hline FYTO BCWS & $\$ 1,588$ & 33,928 & $\$ 5.901$ & $\$ 8,797$ & & & & $T$ & & & & \\
\hline FYTD BCWP & $\$ 1,566$ & 53,054 & $\$ 5,815$ & $\$ 8.662$ & & & & & & & & \\
\hline FYTD ACWP & $\$ 1,369$ & $\$ 4,009$ & $\$ 6.423$ & $\$ 8,765$ & & & & & & & & \\
\hline
\end{tabular}

Note: PHMC cost only (other site contractors not included). 


\section{ISSUES}

\section{Technical Issues}

Issues were self-identified in the WSCF laboratory's conformance to certain customer's (200 ETF, $300 \mathrm{TEDF}$ ) permit-mandated regulatory protocols (sample digestion, holding times and accreditation status).

Impact(s): Impacts could be discharge permit violation depending on the type of samples. A regulatory penalty is unlikely.

Corrective Action: Corrective actions are being taken in each area and customers have been notified to enable impact assessment. Rework of useable archived samples has been done.

\section{DOE/Regulator/External Issues}

Certification of Hanford's TRU Project is necessary to initiate waste shipment to WIPP. Continue working with the Carlsbad Area Office, the Environmental Protection Agency and the New Mexico Environment Department to achieve WIPP certification of Hanford's TRU Project. Complete lab support required for headspace gas sampling and analysis.

\section{Cost Variance Analysis: ( $\$ 0.1 \mathrm{M})$}

\section{WBS/PBS}

Title

\subsection{4/WM06 Analytical Services}

Description/Cause: The unfavorable cost variance is of $\$ 0.1$ million ( 1.1 percent) is within established thresholds.

Impact: No impact.

Corrective Action: None required.

\section{Schedule Variance Analysis: ( \$0.1M)}

\section{WBS/PBS}

1.2.4/WM06

Analytical Services

Description /Cause: The unfavorable schedule variance of $\$ 0.1 \mathrm{M}(1.5$ percent $)$ is within established threshold.

Impact: None

Corrective Action: None required. 


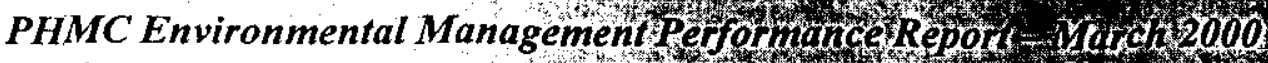

Section B: 2 - Analytical Services (222 S, HASP WSCF

Baseline Change Requests Currently in Process

$(\$ 000)$

\begin{tabular}{|c|c|c|c|c|c|c|c|c|c|}
\hline $\begin{array}{c}\text { PROJECT CHANGE } \\
\text { NUMBER }\end{array}$ & DATE ORIGIN. & BCR TITLE & $\begin{array}{c}\text { FYOO COST } \\
\text { IMPACT } \$ 000\end{array}$ & $\mathrm{SCH}$ & TECH & $\begin{array}{l}\text { DATE TO } \\
\text { CCE }\end{array}$ & $\begin{array}{c}\text { CCB } \\
\text { APRVD }\end{array}$ & $\begin{array}{c}\text { RL } \\
\text { APR'VD }\end{array}$ & CLRRENT STAT \\
\hline$W M-2000-002^{\circ}$ & $1 / 3 / 00$ & $\begin{array}{l}\text { Waste Management FY } 2000 \\
\text { Mandated Funds Reductions }\end{array}$ & $(\$ 878.50)$ & & & $2 / 17 / 00$ & & & $\begin{array}{l}\text { On hold pending } \\
\text { evaluation of perfommance } \\
\text { agreement impacts }\end{array}$ \\
\hline & & & 드 & $\mathrm{AU}$ & |RI & ONS & & & \\
\hline
\end{tabular}

\section{ANALYTICAL SERVICES - WBS 1.2.4 MILESTONE ACHIEVEMENT}

\begin{tabular}{|c|c|c|c|c|c|c|c|c|}
\hline \multirow[b]{2}{*}{ MILESTONE TYPE } & \multicolumn{4}{|c|}{ FISCAL YEAR-TO-DATE } & \multicolumn{3}{|c|}{ REMAINING SCHEDULED } & \multirow[b]{2}{*}{$\begin{array}{c}\text { TOTAL } \\
\text { FY } \\
2000\end{array}$} \\
\hline & $\begin{array}{c}\text { Completed } \\
\text { Early }\end{array}$ & $\begin{array}{c}\text { Completed } \\
\text { On } \\
\text { Schedule }\end{array}$ & $\begin{array}{c}\text { Completed } \\
\text { Late }\end{array}$ & Overdue & $\begin{array}{c}\text { Forecast } \\
\text { Early }\end{array}$ & $\begin{array}{c}\text { Forecast } \\
\text { On } \\
\text { Schedule }\end{array}$ & $\begin{array}{c}\text { Forecast } \\
\text { Late }\end{array}$ & \\
\hline Enforceable Agreemen & of & 0 & 0 & 0 & 0 & of & 0 & 0 \\
\hline DOE-HQ & 0 & 0 & of & 0 & 0 & 0 & 0 & 0 \\
\hline FO & 0 & 0 & 0 & 0 & 0 & 0 & 0 & 0 \\
\hline $\mathrm{RL}$ & 0 & 0 & 0 & 0 & 0 & 1 & 0 & 1 \\
\hline Total Project & 0 & 0 & 0 & 0 & 0 & 1 & 0 & 1 \\
\hline
\end{tabular}

Nothing to report.

Tri-Party Agreement / EA Milestones

DNFSB Commitments

Nothing to report.

\section{MiLestone ExCEPTION REPORT}

\begin{tabular}{|c|c|}
\hline Number/WBS Level & Milestone Title \\
\hline
\end{tabular}

\section{OVERDUE - 0}

FORECAST LATE - 0 


\section{Performance Objectives}

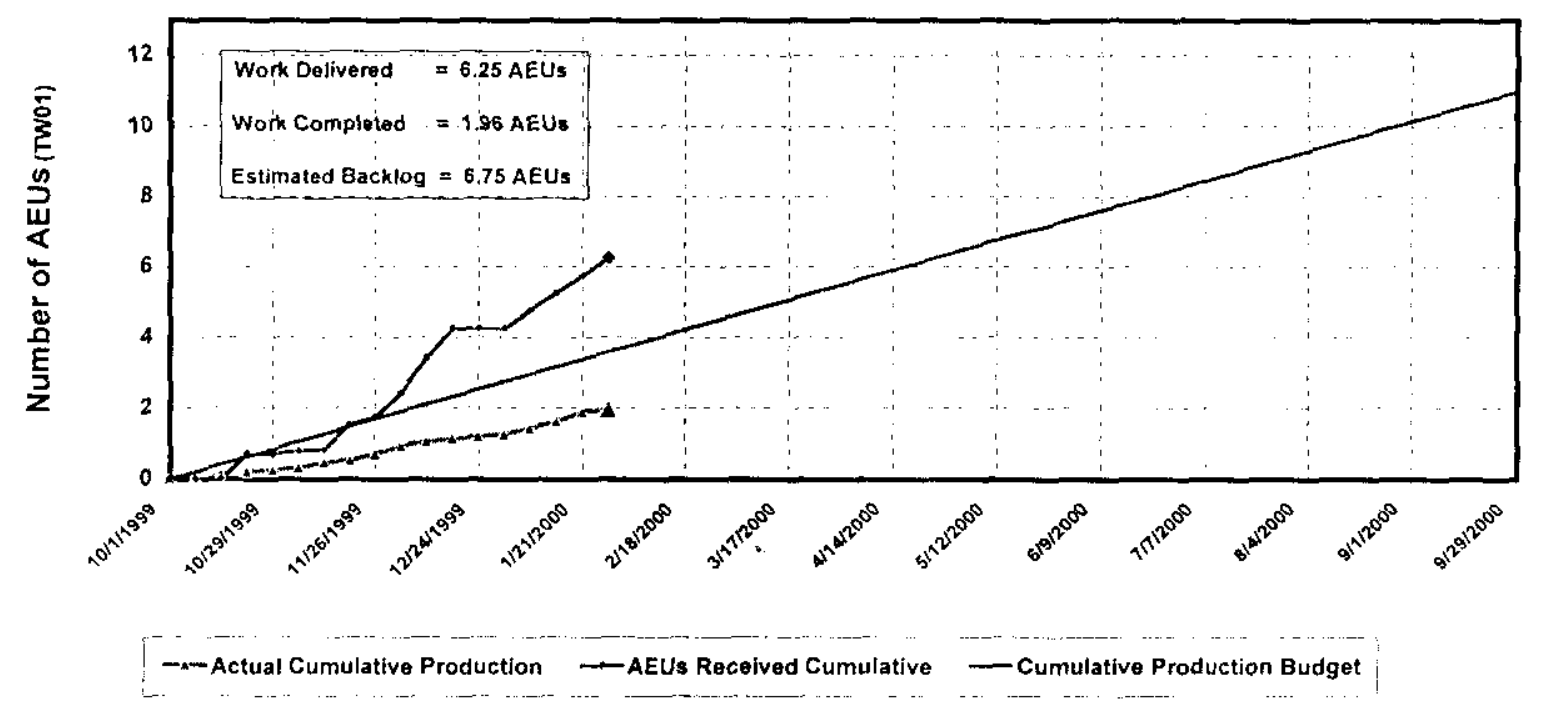

\section{Continue working with RPP on 222-S laboratory production integration. Will meet September 2000 commitment of eleven AEUs.}

\section{KEY INTEGRATION ACTIVITIES}

- $\quad$ Support ORP Privatization Readiness-to-Proceed activities

- Continue to support BNFL efforts to establish required analytical support for glassification operations.

- In the longer term, BNFL could utilize unused space at WSCF for cold run test support and process laboratory analytical equipment testing.

- The 222-S laboratory, with some refurbishment might become a low cost option to a new large scale laboratory associated with the glassification facility

- $\quad$ Continue to support RL with the WSCF path-forward study which evaluates the spectrum of services WSCF provides versus other potential options.

- Discussions by the Site Management Board is planned in late April 2000 
PHMC Énvironmental Management Performance Report-March 2000 Section C-Spent Nuclear Fuel
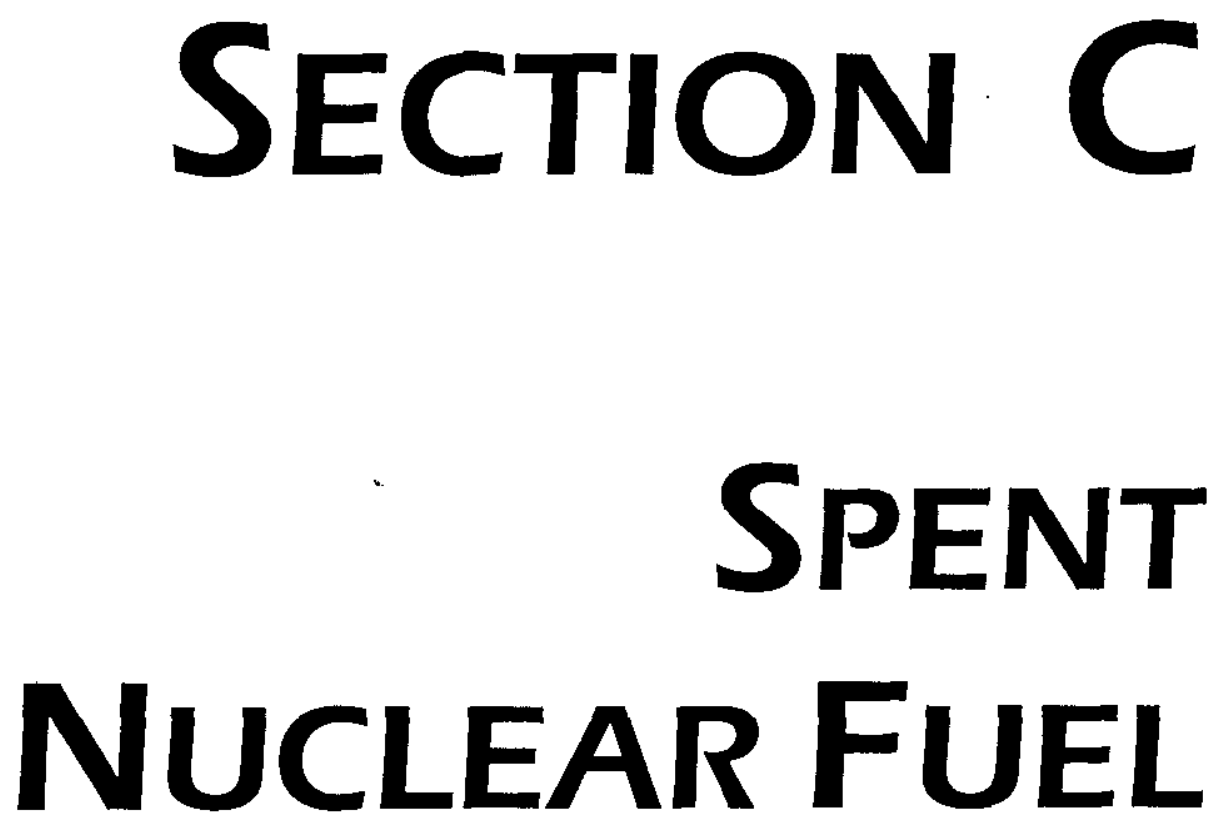

PROJECT MANAGERS

\author{
P. G. Loscoe, RL \\ Phone: (509) 373-7465 \\ R. B. Wilkinson, FH \\ Phone: (509) 372-3030
}




\section{SUMMARY}

The Spent Nuclear Fuel (SNF) mission consists of the Spent Nuclear Fuel Project WBS 1.3.1.1 (Project Baseline Summary [PBS] WM01) and the subsequent Canister Storage Building (CSB) Operations Project WBS 1.3.2.1 (PBS WM02), which doesn't start until FY 2004.

NOTE: Unless otherwise noted, the Safety, Conduct of Operations, and Cost/Schedule data contained herein is as of January 31, 2000. All other information is as of March 1, 2000.

The Canister Storage Building (CSB) is 95 percent complete, compared to 95 percent planned. The Cold Vacuum Drying (CVD) Facility is 89 percent complete compared to 91 percent planned.

The SNF Project continued testing of energized components (i.e., calibration, loop tests, equipment approach) at the Cold Vacuum Drying (CVD) Facility. RL issued the Safety Evaluation Report for the CVD Annex to SNF Project FSAR with conditions for approval.

Fabrication of production Multi-Canister Overpacks (MCO) and MCO baskets continued at Joseph Oat, Inc. and the Hanford Site respectively.

Fiscal year-to-date milestone performance (EA, DOE-HQ, and RL) shows that there are no milestone exceptions. The Milestone Achievement details, found following cost and schedule variance analysis, provide further information on all milestone types.

\section{Accomplishments}

- $\quad$ CSB project is 95 percent complete vs. 95 percent planned.

- $\quad$ CVD Facility is 89 percent complete vs. 91 percent planned.

- $\quad$ Submitted K Basin Safety Analysis Report (SAR), Revision 4 and Technical Safety Report (TSR) to RL on January 24, 2000. Also, submitted draft of Canister Storage Building Final Safety Analysis Report (FSAR) and TSR to RL on January 31, 2000.

- Closed last major technical issue on fuel crumbling and issued closure package.

- $\quad$ Phased Startup Initiative (PSI) Phase 1 testing commenced January 27, 2000. Results have produced many benefits including correction of material problems, procedure verification, organizational alignment, and improved operational readiness many months ahead of the baseline schedule.

- Completed installation of the K West MCO Loading System (MLS) gantry as part of the Cask Loadout System (CLS). This completes all major construction activities in K West Basin in preparation for fuel movement. 
- Completed final welding on all of the Canister Storage Building storage tubes. This completes all major construction activities required for receipt of fuel from the CVD Facility.

- Completed M-34-04 "Submit Remedial Design Report/Remedial Action Work Plan for K Basins" ahead of schedule. Completed M-34-14A, "Complete K West Basin Cask Facility Modifications" on schedule.

- $\quad$ The Baseline Change Request (BCR) for the sludge acceleration strategy was submitted to $\mathrm{RL}$ for review and approval. This strategy will accelerate completion of sludge removal from the K Basins by one year, while reducing the SNF Project total project cost by approximately $\$ 16$ million.

- The SNF Project Organization was revised this week to align the organization for support of operations. Testing and turnover of systems and facilities is well underway and the revised organization will support efforts to achieve readiness for an Operational Readiness Review.

\section{SAFETY}

Although the SNF Project experienced some safety performance degradations with the start of FY 2000, performance appears to be recovering. October 1999 had 2 Restricted Workday Cases, and 1 Lost Away Workday Case. This was a nearly significant increase on the OSHA Recordable Case Rate, and a significant increase (above the UCL) on the Lost / Restricted Workday Case Rate (which is a supplemental graph). 


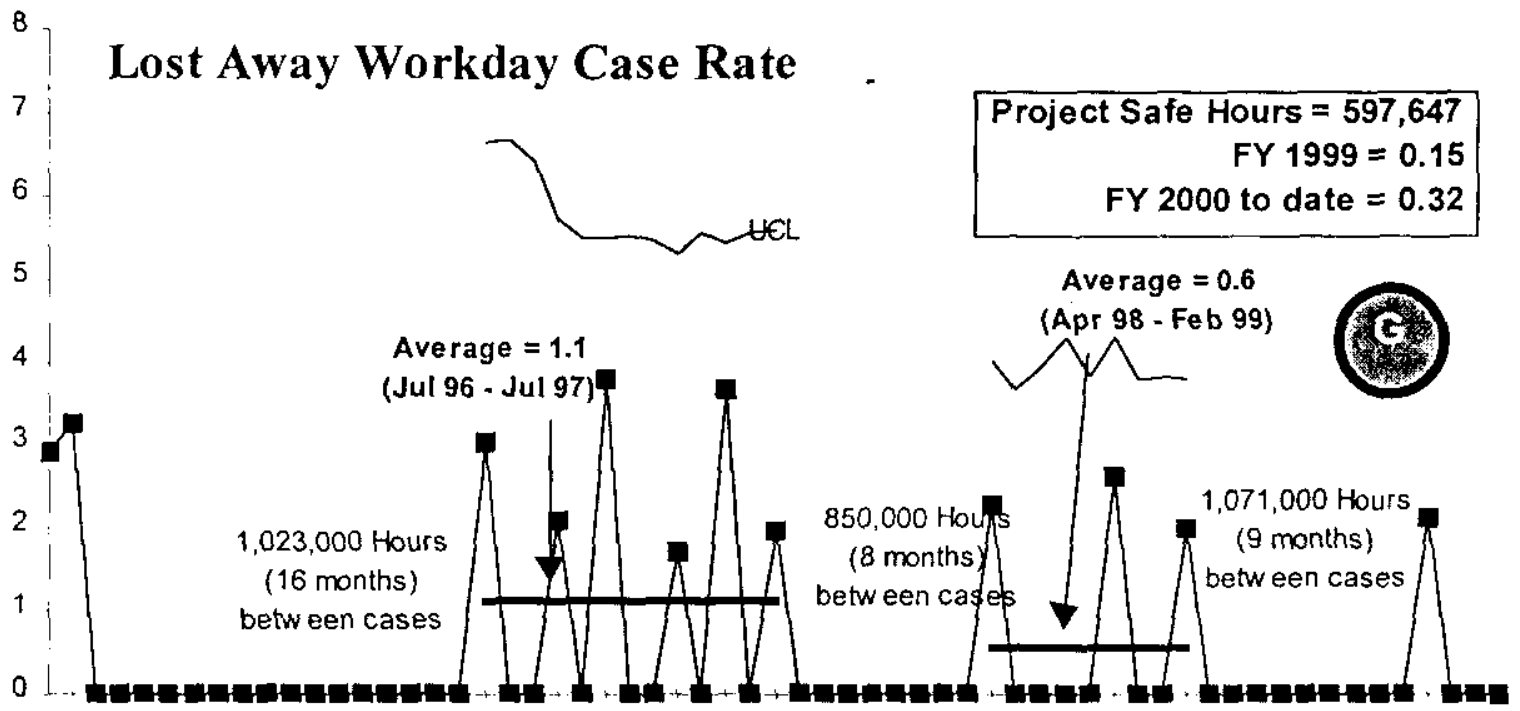

\section{OSHA Recordable Case Rate}

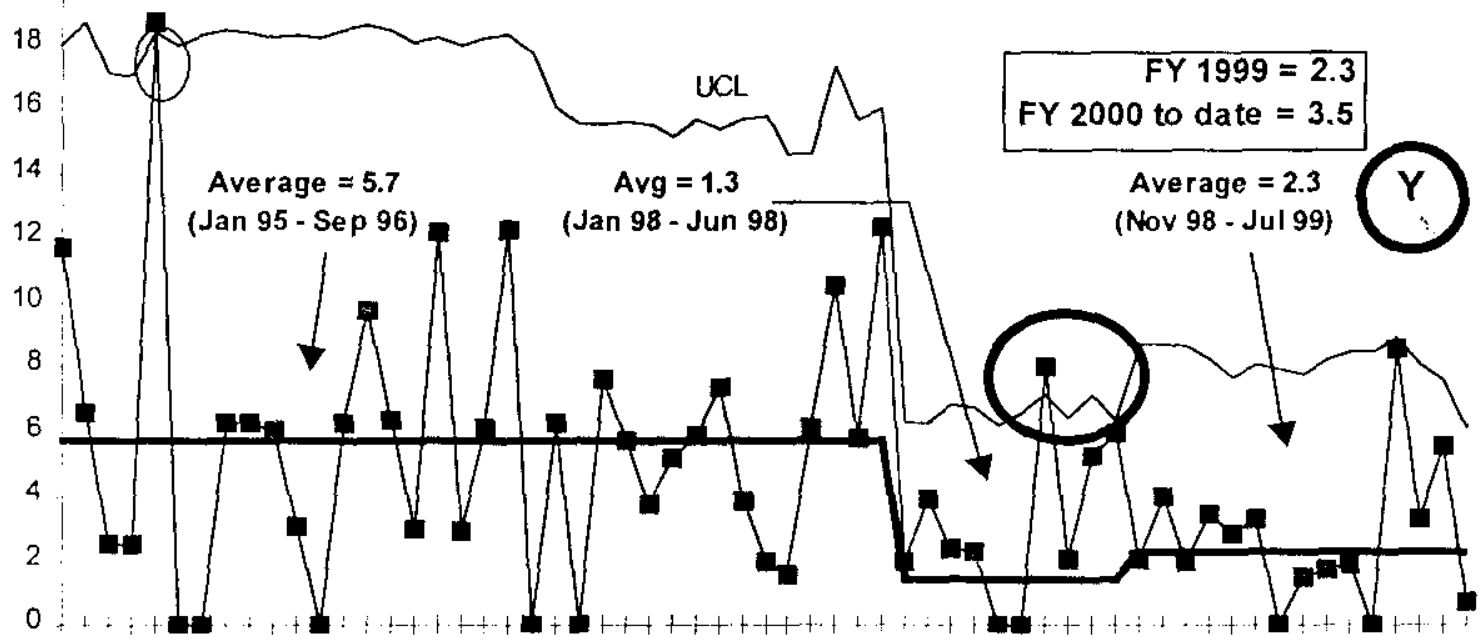

Increased management and worker attention have been provided

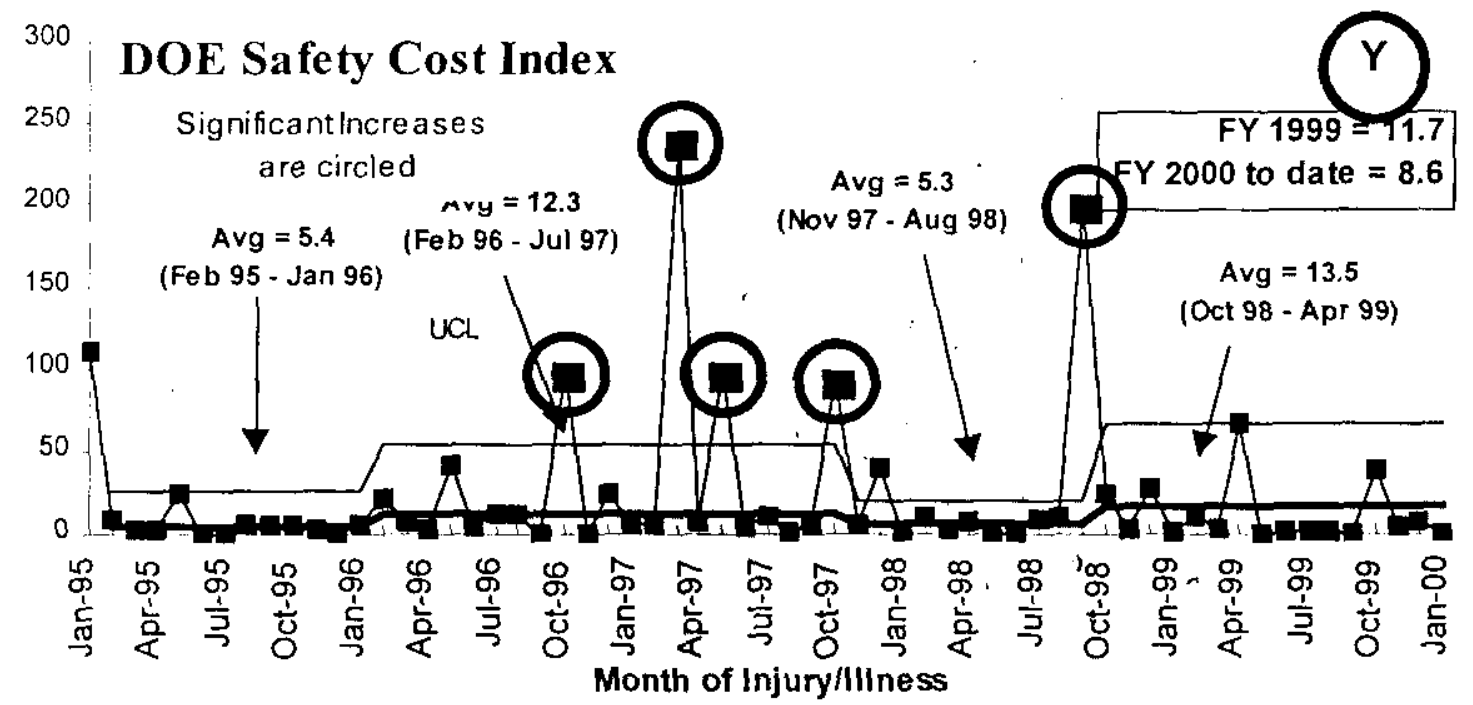

Trend is improving. 


\section{CONDUCT OF OPERATIONS / ISMS STATUS \\ CONDUCT OF OPERATIONS}

\section{Events per 200,000 hours}
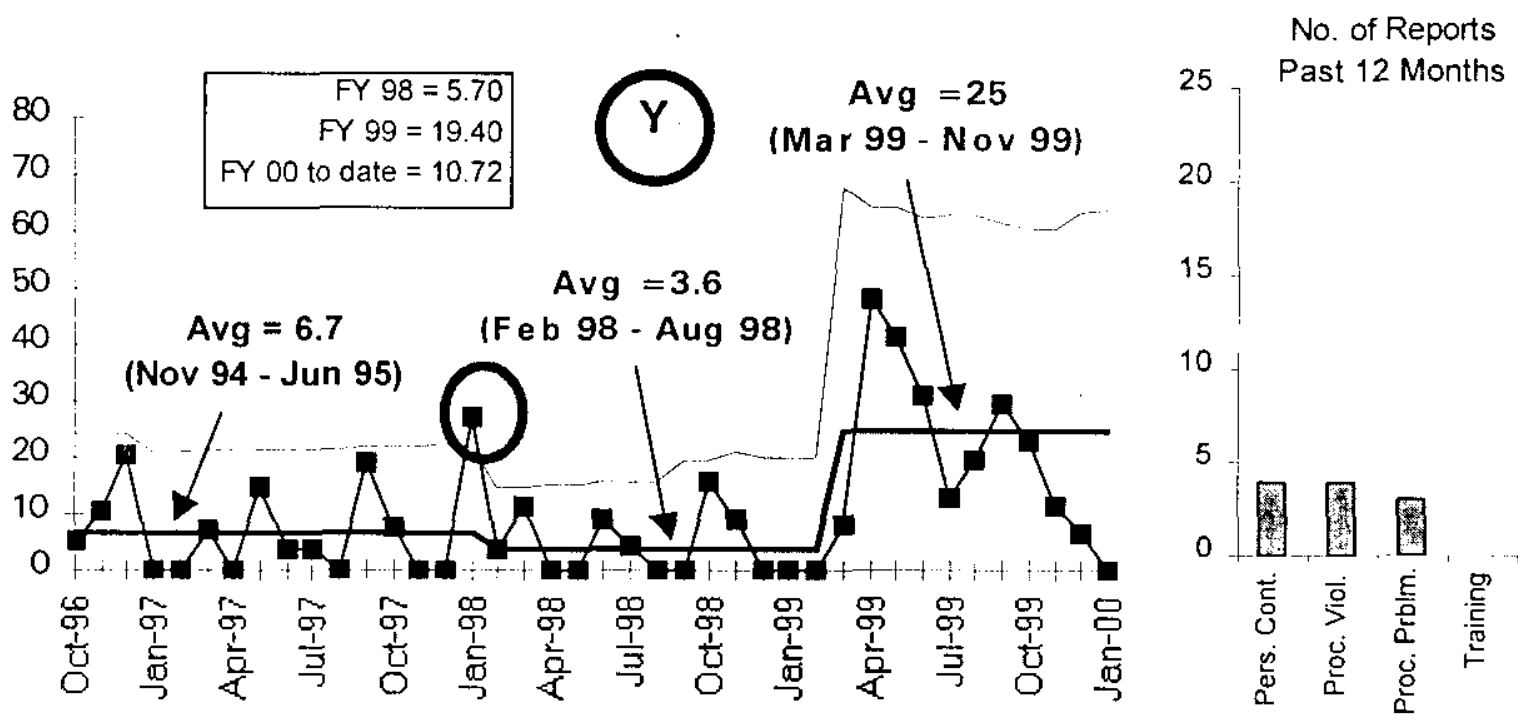

Trend is improving.

\section{ISMS STATUS}

Yellow

- $\quad$ The ISMS Phase I/II verification for the SNF Project was completed on November 19, 1999

- The Corrective Action Plans for the "Opportunities for Improvement" were developed and transmitted to RL on January 10,2000

- $\quad$ The actions required to enable ISMS implementation to be declared March 31, 2000 are on schedule.

Green

\section{BREAKTHROUGHS / OPPORTUNITIES FOR IMPROVEMENT}

\section{Breakthroughs}

SNF Project has submitted a Baseline Change Request which implements a strategy to accelerate sludge removal by one year and reduce total project cost.

\section{Opportunities for Improvement}

Green

Phased Startup Initiative (PSI) -- Results from the PSI are expected to improve the fuel production rates by approximately one month in FY 2001. 


\section{UPCOMING ACTIVITIES}

Phased Startup Initiative -- Complete PSI Phases $1 \& 2$ by mid-April 2000. Complete Phases 3 \& 4 by mid-August 2000.

Storage Projects -- Deliver first shipment of Multi-Canister Overpacks (MCOs) and baskets by June 1, 2000.

Fuel Removal Activities -- Begin DOE Operational Readiness Review by mid September 2000. Begin K West Basin fuel removal, drying \& storage operations by November 30, 2000.

Sludge Removal Activities -- Baseline Change Request due to be submitted February 2000 will affect a one year acceleration of the completion of $\mathrm{K}$ Basin sludge removal.

\section{Cost Performance (\$M):}

\begin{tabular}{|l|c|c|c|}
\hline & BCWP & ACWP & VARIANCE \\
\hline Waste Management & $\$ 47.0$ & $\$ 62.4$ & $-\$ 15.4$ \\
\hline
\end{tabular}

Further information on the unfavorable cost variance of $\$ 15.4$ million (32.8 percent) can be found at the PBS level in the following Cost Variance Analysis details.

\section{Schedule Performance (\$M):}

\begin{tabular}{|l|c|c|c|}
\hline & BCWP & BCWS & VARIANCE \\
\hline Waste Management & $\$ 47.0$ & $\$ 55.5$ & $-\$ 8.5$ \\
\hline
\end{tabular}

Further information on the unfavorable schedule variance of $\$ 8.5$ million (15.4 percent) can be found in the following Schedule Variance Analysis details.

\section{Spent Nuclear Fuel Project Status WBS 1.3 \\ FYTO}

By PBS

RL-WM01 Spent Nuclear Fuel Project

Total

$\begin{array}{llllllllllll}\$ 55,545 & \$ 47,007 & \$ 62,408 & -8538 & -15 \% & -15401 & -33 \% & \$ & 195,100 & \$ 195,074 & 0 \\ \$ & \$ 55,545 & \$ 47,007 & \$ 62,408 & -8538 & -15 \% & -15401 & -33 \% & \$ & 195,100 & \$ & \$ 195,074\end{array}$

$\begin{array}{llllllll}\text { BCWS BCWP ACWP SV } & \% & \text { CV } & \% & \text { Auth Bsin PTS BCWS Funding }\end{array}$

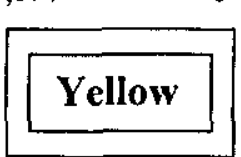




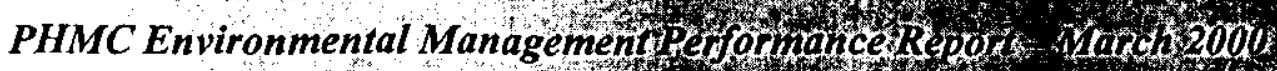

Section C-Spent Nuclear Fuel

\section{Cost/Schedule Performance Indices (JANUARY 2000 AND FYTD)}

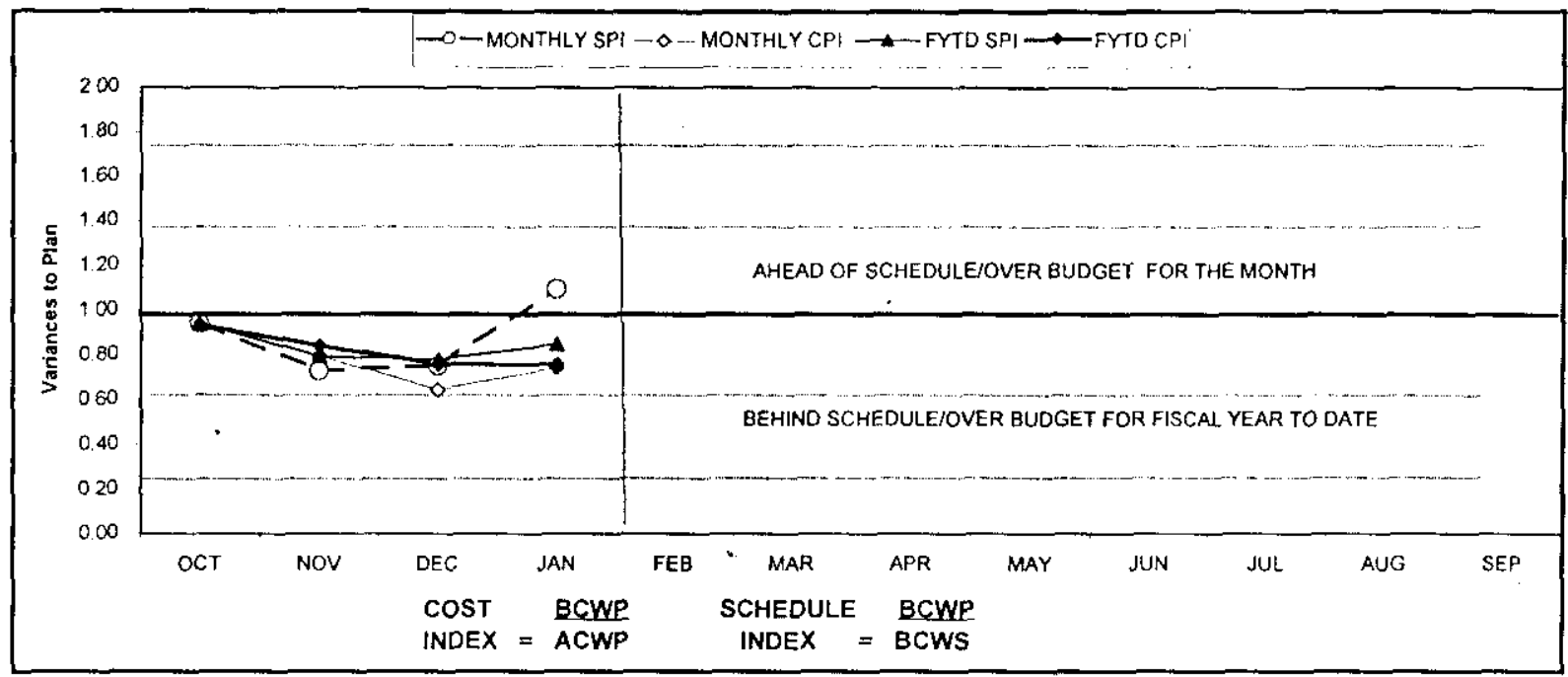

\begin{tabular}{|c|c|c|c|c|c|c|c|c|c|c|c|c|}
\hline FY 2000 & OCT & NOV & DEC & JAN & FEB & MAR & APR & MAY & JUN & JUL & AUG & SEP \\
\hline MONTHLY SPI & 0.94 & 0.73 & 0.75 & 1.09 & & & & & & & & \\
\hline MONTHLY Y CP & 0.93 & 079 & $0 \overline{64}$ & 0.74 & & & & & & & & \\
\hline FYTD SPI & 0.94 & 0.79 & 0.78 & 0.85 & & & & & & & & \\
\hline FYTT CPI & 0.93 & 0.84 & 0.76 & 0.75 & & & & & & & $\therefore$ & \\
\hline MONTHLY BCWS & $\$ 8,574$ & $\$ 19.209$ & $\$ 15,681$ & 512,081 & & & & & & & & \\
\hline MONTHEY BCWP & $\$ 8,049$ & $\$ 13.968$ & $\$ 11.769$ & $\$ 13,221$ & & & & & & & & \\
\hline MONTHLY ACWP & $\$ 8,626$ & $\$ 17.581$ & $\$ 18,361$ & $\$ 17.840$ & & & & & & & & \\
\hline FYTDECVIS & $\$ 8,574$ & $\$ 27,783$ & $\$ 43,464$ & $\$ 55,545$ & & & & & & & & \\
\hline FYTO BCWP & $\$ 8,049$ & $\$ 22.017$ & $\$ 33,786$ & $\$ 47,007$ & & & & & & & & \\
\hline FYTD ACWP & $\$ 8,626$ & $\$ 26,207$ & $\$ 44.568$ & $\$ 62,408$ & & & & & & & & \\
\hline
\end{tabular}

\section{ISSUES}

\section{Technical Issues}

None.

\section{DOE/Regulator/External Issues}

Nothing to report. 


\section{COST VARIANCE ANALYSIS: (- \$15.4)}

\section{$\underline{\text { WBS/PBS }} \quad \underline{\text { Title }}$}

\subsection{1/WM01 Spent Nuclear Fuel Project}

Description/Cause: The unfavorable cost variance of $\$ 15.4 \mathrm{M}$ (32.8 percent) is due to completion of $\mathrm{K}$ West construc tion workscope is more than planned. Overdue due to SNF Project fee requirements resulting from Site Restructure. Need for additional engineering is required to support MSA, ORR and startup functions Corrective Action Management activities were not budgeted in FY 2000.

Impact: Projected year end overrun.

Corrective Action: Sources are being evaluated.

\section{SCHEDUle VARIANCE ANALYSIS: (- \$8.5)}

\section{WBS/PBS}

\subsection{1/ WMO1}

1.3.1/

Cause: The unfavorable schedule variance of $\$ 8.5 \mathrm{M}(15.4 \%$ percent $)$ is due to $\mathrm{K}$ East Basin construction projects behind schedule due to work not fully progressed and IWTS K East fabrication and construction workscope not being performed as a result of new design requirements.

Impact: No Impact.

Corrective Action: Path Forward BCR in process to reschedule this work.

\section{Baseline Change Requests Currently in Process} (\$000)

\begin{tabular}{|c|c|c|c|c|c|c|c|c|c|}
\hline $\begin{array}{l}\text { PROJECT } \\
\text { CHANGE } \\
\text { NUMBER }\end{array}$ & $\begin{array}{c}\text { DATE } \\
\text { ORIGIN. }\end{array}$ & BCR TITLE & $\begin{array}{l}\text { FYOO COST } \\
\text { IMPACT } \$ 000\end{array}$ & $\mathrm{SCH}$ & TECH & $\begin{array}{l}\text { DATE TO } \\
\text { CСB }\end{array}$ & $\begin{array}{c}\text { CCB } \\
\text { APR'VD }\end{array}$ & $\begin{array}{c}R L \\
\text { APR'VD }\end{array}$ & $\begin{array}{l}\text { CURRENT } \\
\text { STATUS }\end{array}$ \\
\hline $\begin{array}{l}\text { SNF-2000-008 } \\
\text { SNF-2000-009 } \\
\text { SNF-2000-012 }\end{array}$ & $\begin{array}{l}\text { SNF-2000- } \\
\text { SNF-2000- } \\
\text { SNF-2000- }\end{array}$ & $\begin{array}{l}\text { Change Path Forward for K-Basin } \\
\text { Sludge from Interim Storage in TWRS } \\
\text { Double-Shell Tanks to T Plant } \\
\text { Sludge Acceleration Strategy } \\
\text { Site Wide SNF Reschedule Due to } \\
\text { Hanford Site Priorities }\end{array}$ & $\langle \$ 1,300\rangle$ & $\begin{array}{l} \\
Y \\
Y\end{array}$ & $\begin{array}{l}Y \\
Y \\
Y\end{array}$ & $\begin{array}{l}1 / 5 / 00 \\
2 / 24 / 00\end{array}$ & $\begin{array}{ll}1 / 5 / 00 \\
2 / 25 / 00 & \end{array}$ & $2 / 17 / 00$ & $\begin{array}{l}\text { Received RL CO } \\
\text { signature, } 2 / 17 / 2000 . \\
\text { Transmitted to RL } \\
2 / 28 / 00 \text {. } \\
\text { In preparation. }\end{array}$ \\
\hline \multicolumn{10}{|c|}{ ADVANCE WORK AUTHORIZATIONS } \\
\hline
\end{tabular}




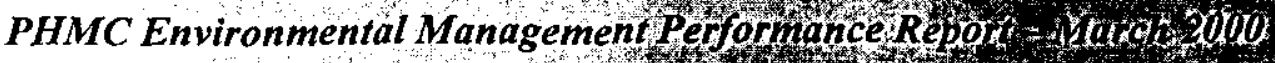

Section C-Spent Nuclear Fuel

\section{SPENT NUCLEAR FUELS - WBS 1.3 MILESTONE ACHIEVEMENT}

\begin{tabular}{|c|c|c|c|c|c|c|c|c|}
\hline \multirow[b]{2}{*}{ MILESTONE TYPE } & \multicolumn{4}{|c|}{ FISCAL YEAR-TO-DATE } & \multicolumn{3}{|c|}{ REMAINING SCHEDULED } & \multirow[b]{2}{*}{$\begin{array}{c}\text { TOTAL } \\
\text { FY } \\
2000\end{array}$} \\
\hline & $\begin{array}{c}\text { Completed } \\
\text { Early }\end{array}$ & $\begin{array}{c}\text { Completed } \\
\text { On } \\
\text { Schedule }\end{array}$ & $\begin{array}{c}\text { Completed } \\
\text { Late }\end{array}$ & Overdue & $\begin{array}{c}\text { Forecast } \\
\text { Early }\end{array}$ & $\begin{array}{c}\text { Forecast } \\
\text { On } \\
\text { Schedule }\end{array}$ & $\begin{array}{c}\begin{array}{c}\text { Forecast } \\
\text { Late }\end{array}\end{array}$ & \\
\hline Enforceable Agreement & 0 & 0 & 0 & 0 & 0 & 2 & 0 & 2 \\
\hline DOE-HQ & 0 & 0 & 0 & 0 & 0 & 0 & 0 & $\underline{0}$ \\
\hline RL & 0 & 0 & 0 & 0 & 0 & 4 & 0 & 4 \\
\hline Total Project & 0 & 0 & 0 & 0 & 0 & 6 & 0 & 6 \\
\hline
\end{tabular}

Tri-Party Agreement / EA Milestones

M-34-14A (S06-97-009), "Complete K West Basin Cask Facility Modifications", due 2/29/00 Completed on schedule.

M-34-04 (S01-99-124), "Submit Remedial Design Report/Remedial Action Work Plan for the K Basins", due $3 / 31 / 00$ - Completed over 1 month early $(2 / 10 / 00)$.

M-34-15B-T01, "Complete remaining bay(s) of the Cold Vacuum Drying Facility construction and installation", due 6/30/00 - On schedule.

M-34-13B-T01, "Complete construction and installation of K East Basin Spent Nuclear Fuel Retrieval System", due $11 / 30 / 00$ - On schedule.

M-34-16 (S00-01-900), "Initiate removal of K West Basin Spent Nuclear Fuel", due 11/30/00 On schedule.

M-34-06-T01, "Initiate $\mathrm{K}$ West Basin spent nuclear fuel canister cleaning operations", due $12 / 31 / 00$ - On schedule.

DNFSB Commitments

Nothing to report.

\section{MILESTONE EXCEPTION REPORT}




\section{Performance Objectives}

RC-1-1.a-I Readiness for Fuel Movement -- Contractor completion of construction and operational testing, Management Self-Assessment, and Independent ORR by $9 / 14 / 00$ to begin moving fuel by $11 / 30 / 00$. Start of fuel movement is currently on track for $11 / 30 / 00$.

RC-1-1.a-II Phased Startup Initiative (PSI) -- Complete PSI Phases $1 \& 2$ by April 15, 2000. This includes successful Cold Testing of IWTS \& FRS. This activity is on schedule.

Green

Green

RC-1-1.b K East Fuel Retrieval System -- Complete facility modification necessary to allow FRS installation by September 30,2000, as defined in the MYWP. Baseline Change Request in process to change this activity with implementation of new strategy.

RC-1SS-1 Accelerate Fuel Movement -- Accelerate start of fuel movement by two months.

RC-1SS-2 Phased Startup Initiative (PSI) -- Complete Phases 3 \& 4 by August 15,2000. This includes completion of FRS/IWTS system testing using SNF (real fuel) and completion of CCD2. This activity is on schedule.

Yellow

Green

\section{KEY INTEGRATION ACTIVITIES}

- $\quad$ Spent nuclear fuel (SNF) final disposition interface activities, including OCRWM QA Program implementation, ongoing with National SNF Program.

- $\mathrm{K}$ Basins sludge removal and Shipping port Pressurized Water Reactor Core 2 SNF removal implementation activities ongoing with Waste Management; Baseline Change Requests are in preparation by the SNF Project and Waste Management to support integrated activity for accelerated sludge removal strategy. Funding authorized for initial T-Plant readiness activities.

- $\quad 324$ Building (B Cell) SNF removal acceptance criteria and conceptual design reviews ongoing with River Corridor Project.

- Neutron Radiography Facility, Training, Research and Isotope Production, General Atomics (TRIGA), and FFTF SNF relocation planning ongoing with FFTF Project

- Input provided to BHI on recovery actions required if SNF is discovered during upcoming reactor basins deactivation. 

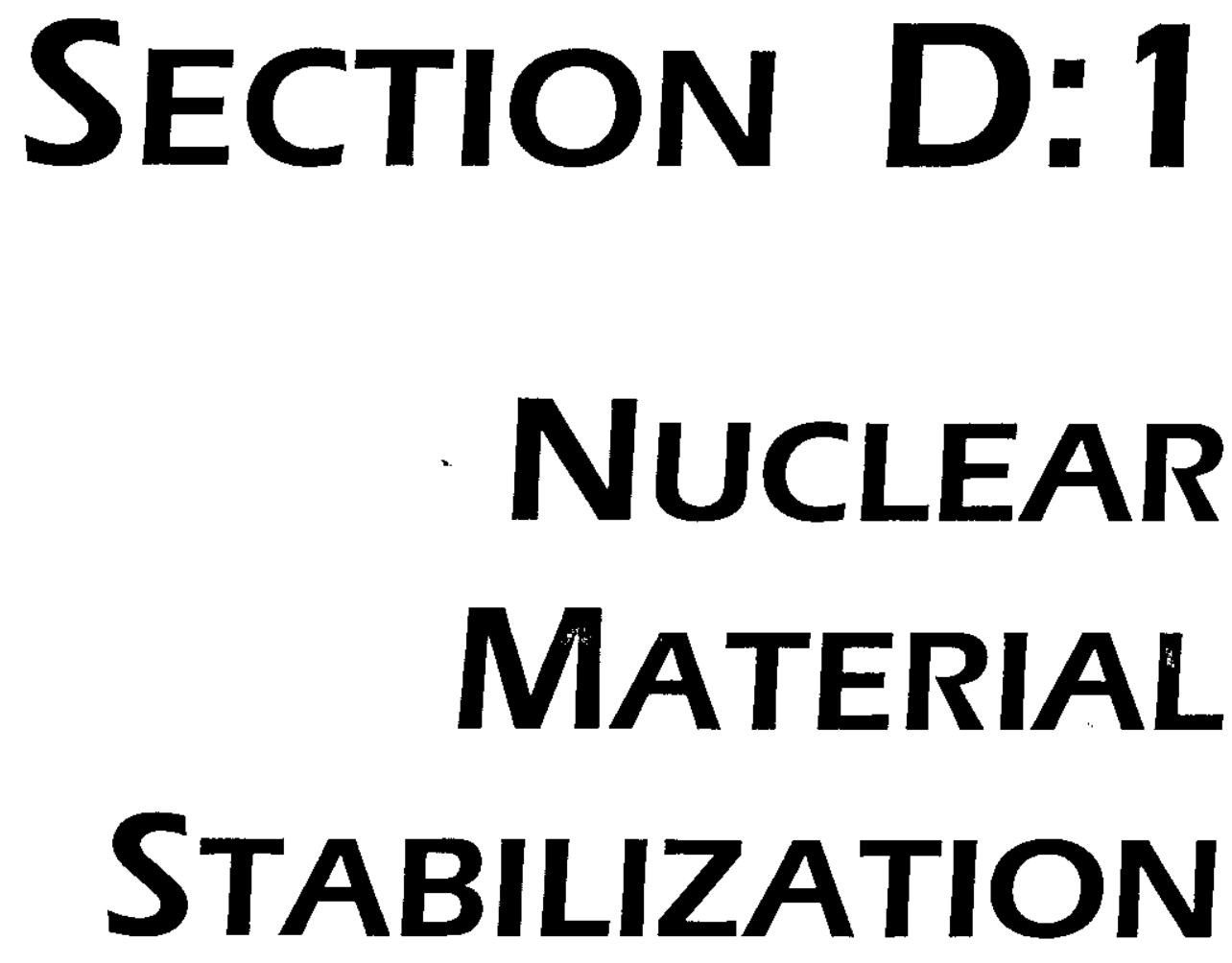

PROJECT MANAGERS

\author{
P. M. Knollmeyer, RL \\ Phone: (509) 376-7435 \\ L. J. Olguin, FH \\ Phone: (509) 372-8233
}




\section{SUMMARY}

The Nuclear Material Stabilization mission consists of the Plutonium Finishing Plant (PFP), WBS 1.4.5, PBS TP05.

NOTE: Unless otherwise noted, the Safety, Conduct of Operations, and Cost/Schedule data contained herein is as of January 31,2000. All other information is as of March 1, 2000.

As of January 2000 a total of 173 cans of Plutonium oxides and sludges have been stabilized through thermal stabilization ( 9 items in January 2000). A total of 13 liters of Plutonium nitrate solution have been stabilized in the prototype vertical denitration calciner.

Progress continues on the installation of three additional muffle furnaces for thermal stabilization of oxides and on installation of the $\mathrm{Mg}(\mathrm{OH})_{2}$ process system.

Fiscal-year-to-date milestone performance (EA, DOE-HQ, and RL) shows that two milestones (67 percent) were completed on or ahead of schedule, no milestones were completed late, and one (33 percent) is overdue. Milestone (TRP-00-500) is late due to a proposed change in process implementation. A letter was sent to RL indicating the milestone would not be met. Further details can be found in the milestone exception report following the cost and schedule variance analysis.

\section{ACCOMPLISHMENTS}

- $\quad$ Two main power supply temporary transformers (\#2 and \#6 for 234-5Z and 291-Z) were installed and placed in service.

- The Remote Mechanical C Line main (refilled) Halon bottles were installed and a major Preventive Maintenance (PM) completed allowing several Fire System restrictions to be cleared.

- Initiated accelerated muffle furnace cool-down work plan; and early tests indicate significant savings in the time required for cool-down during muffle furnace operation, which will improve stabilization productivity.

- $\quad$ Progress continued on startup of three additional muffle furnaces. RL approved the revised Operational Safety Requirements (OSR\$) reflecting the new furnaces. Reviewed furnace operations from a NEPA perspective and concluded no additional documentation required. Fabricated new boats, covers and furnace table completing procurement of all required spare parts for operation.

- Obtained DOE-RL concurrence on the criteria document for the $\mathrm{Mg}(\mathrm{OH})_{2}$ safety analysis.

- $\quad$ PNNL testing continued in support of revised polycube stabilization path forward. Phase I testing has been completed. Phase II testing will begin in February. 
- $\quad$ Plutonium Oxide Stabilization - A total of 173 cans of oxides/sludges have been stabilized (9 items in January 2000).

- $\quad$ Plutonium Nitrate Solution Stabilization - A total of 13 liters of solution have been stabilized. The magnesium hydroxide precipitation glovebox fabrication is proceeding on schedule.

- $\quad$ Project W-460 - The contract for the Bagless Transfer System Glovebox has been issued. Delivery of this system to Hanford is expected June 8, 2000, two weeks ahead of schedule.

\section{SAFETY}

Safety performance has significantly improved in January with no OSHA Recorable or Lost Workday Case injury and no First Aid Cases.

Case reclassifications and additional days on open cases have caused readjustments of past data. There continues to be a growth in lost/restricted days for February 1999.

The past seven months were below average on the Cost Index. OSHA recordable case rate has significantly improved in comparison to the adverse trend of Spring 1999. An initial baseline rate of 2.5 has been calculated, which is equal to the PHMC overall rate. 
12. Lost Away Workday Case Rate
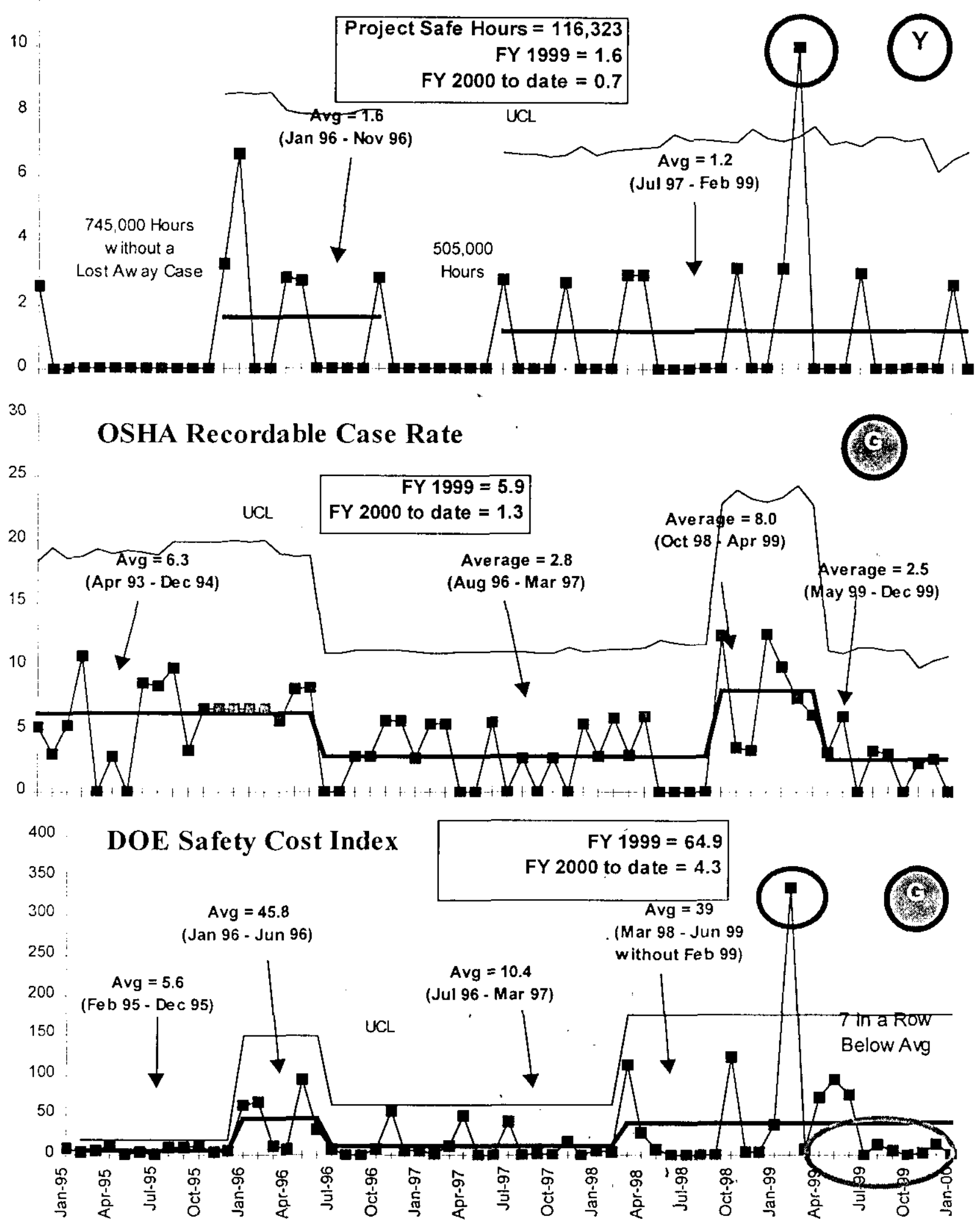


\section{CONDUCT OF OPERATIONS / ISMS STATUS \\ CONDUCT OF OPERATIONS \\ Events per 200,000 Hours}

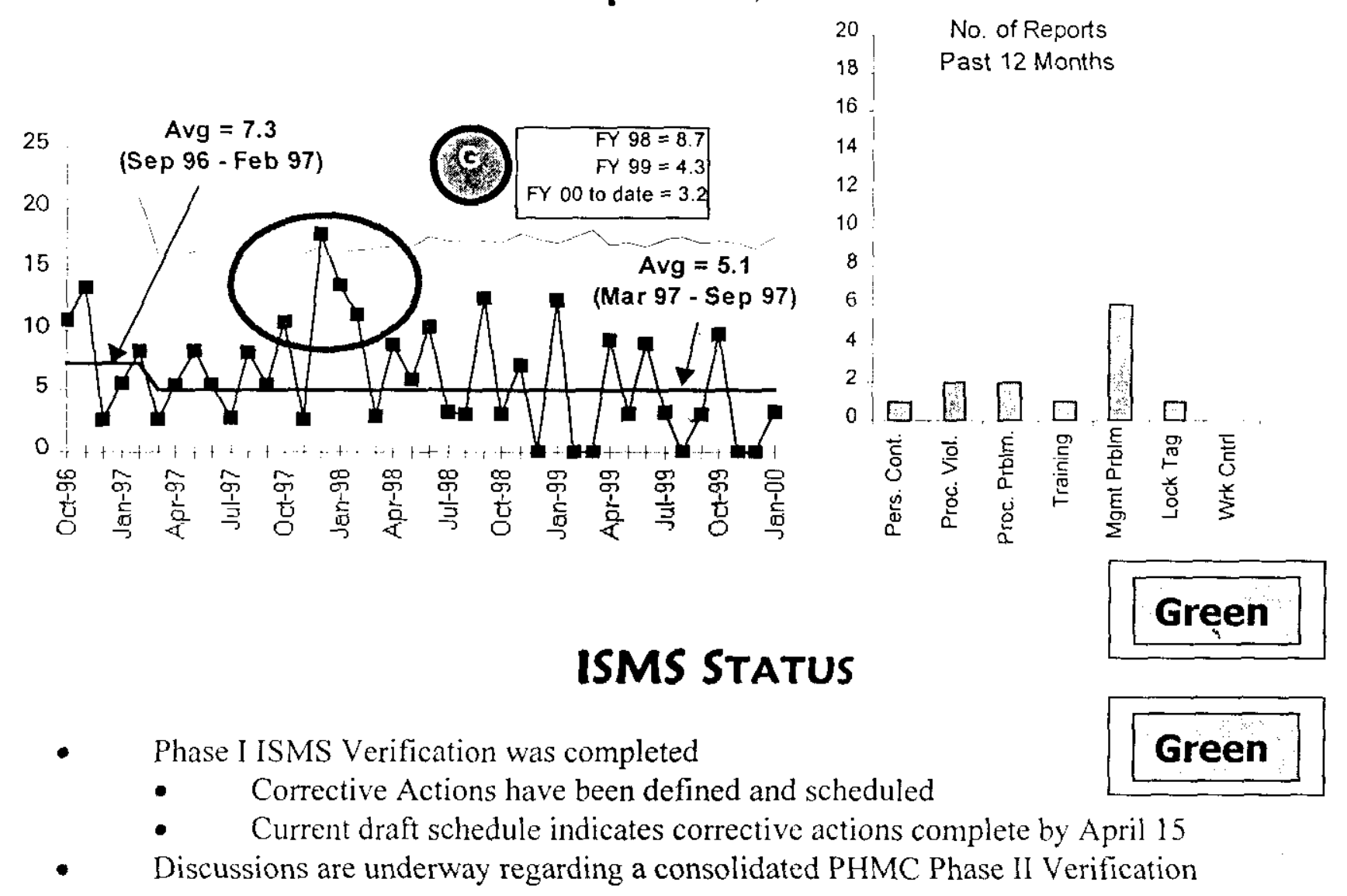

\section{BREAKTHROUGHS / OPPORTUNITIES FOR IMPROVEMENT}

\section{BREAKTHROUGHS}

- Nothing to report.

\section{OPPORTUNITIES FOR IMPROVEMENT}

- $\quad$ Efforts to accelerate all phases of the clearance process continue with the assistance of DOE-RL. NMS is actively engaged in adding appropriate staff to catch back corresponding schedule delays.

Yellow

- There is a need to identify and consolidate various cost saving initiätives resulting from increased operating efficiencies. Conduct a summit meeting of all parties to maximize efforts and direct savings to accelerate Green stabilization activities. 
- Initiated accelerated furnace cool-down work plan and early tests indicate a significant savings in time required for cool-down. Opening the furnace doors at 400 degrees increased the glovebox temperature only two degrees temporarily and saved over three hours in the cooling time. Expect to be able

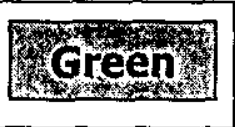
to continue to at least 600 degrees without negative effects.

\section{UPCOMING ACTIVITIES}

- Complete furnace cool-down tests and implement new procedures

- $\quad$ Begin Pu solution stabilization via $\mathrm{Mg}(\mathrm{OH})_{2}$ in FY 2000

- Deliver glove boxes and equipment for installation by April 11,2000

- Complete ORR and training activities

- $\quad$ Startup Cementation by April 21, 2000

- Complete Pipe-and-Go evaluation and long lead regulatory permits

- Complete W-460 Facility Design by April 2000

- Complete installation and startup of the BTS by October 2000

- Begin metal stabilization processing in November 2000

\section{COST PERformanCe $(+\$ 5.5 \mathrm{M})$ :}

\begin{tabular}{|l|c|c|c|}
\hline & BCWP & ACWP & VARIANCE \\
\hline Nuclear Material Stabilization & $\$ 35.9$ & $\$ 30.4$ & $\$ 5.5$ \\
\hline
\end{tabular}

The $\$ 5.5$ million ( 15.3 percent) favorable cost variance is duc to a shortage of staff and, a lag in costs for contracts [(e.g., including the Energy Services contract for steam, $\mathrm{Mg}(\mathrm{OH})_{2}$ glove box procurement, etc].

\section{Schedule Performance ( $\$-5.3 M)$ :}

\begin{tabular}{|l|c|c|c|}
\hline & BCWP & BCWS & VARIANCE \\
\hline Facility Stabilization & $\$ 35.9$ & $\$ 41.2$ & $-\$ 5.3$ \\
\hline
\end{tabular}

The $\$ 5.3$ million (12.9 percent) unfavorable schedule variance is due primarily to the behind status on Project W-460 vault modification construction awaiting final determination from EIS Supplement Analysis and equipment procurements, such as glove boxes, NDA lab equipment and outer can welder activities. Also, Project W-460 trailer installation activities have not started as scheduled but instead will be removed as part of the DOE-HQ directed 5\% funding reduction in FY 2000 . Also contributing to the unfavorable schedule variance is the behind schedule status on special projects (sanitary water system upgrade, Criticality Alarm Panel upgrade and radiation monitoring constant air monitor upgrade); and, late startup on core sample analyses at the $222-\mathrm{S}$ Analytical Laboratory from tank 241-Z-361. 
PHMC Environmental Management Perfornance Report 1 Horch 8000

Section D: 1 -Nuclear Material Stabilization

FY 2000 Cost/Schedule Performance - All Fund Types

NuClear Materials Stabilization Project

WBS 1.4.52

Cumulative to Date Status - $(\$ 000)$

FYTD

$\begin{array}{lllllllll}\text { By PBS } & \text { BCWS BCWP ACWP } & \text { SV } & \% & \text { CV } & \% & \text { Bsin } & \text { BCWS }\end{array}$

TP05

Total

\begin{tabular}{lllllllll}
$\$ 41.2$ & $\$ 35.9$ & $\$ 30.4$ & $\$(5.3)$ & $-13 \%$ & $\$ 5.5$ & $15 \%$ & $\$ 125.4$ & $\$ 127.9$ \\
\hline$\$ 41.2$ & $\$ 35.9$ & $\$ 30.4$ & $\$(5.3)$ & $-13 \%$ & $\$ 5.5$ & $15 \%$ & $\$ 125.4$ & $\$ 127.9$
\end{tabular}

Yellow

RL-Directed costs (steam) are included in the PTS BCWS.

\section{Nuclear Materials Stabilization Project \\ COST/SCHEDULE PERformanCE INDICES (JANUARY 2000 AND FYTD)}

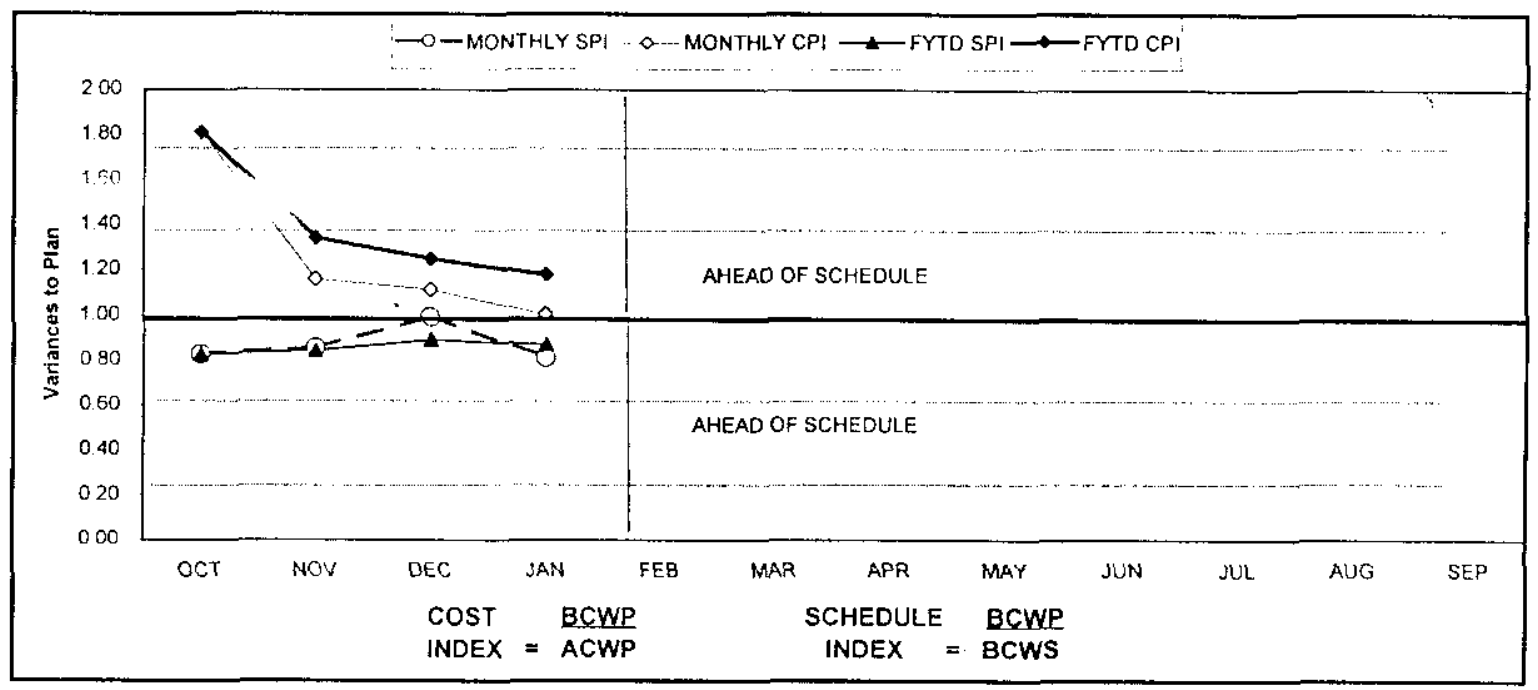

\begin{tabular}{|c|c|c|c|c|c|c|c|c|c|c|c|c|}
\hline FY 2000 & OCT & NOV & DEC & JAN & FEB & MAR & APR & MAY & JUN & JUL & AUG & SEP \\
\hline MONTHLY SPI & 083 & 085 & 0.99 & 0.81 & & & - & & & & & \\
\hline MONTHLY CPI & 181 & 1.16 & 111 & 1.01 & & & & & & & & \\
\hline FYTD SPI & 0.83 & 0.84 & 089 & 0.87 & & & & & & & & \\
\hline FYYD CPI & 1.81 & 1.34 & 1.25 & 1.18 & & & & & & & & \\
\hline MONTHLY BCWS & $\$ 7,913$ & $\$ 12,723$ & $\$ 9.919$ & $\$ 10,631$ & & & & & & & & \\
\hline MONTHLY BCWP & $\$ 6,543$ & $\$ 10,873$ & $\$ 9.849$ & $\$ 8.638$ & 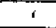 & & & & & & & \\
\hline
\end{tabular}




\section{ISSUES}

DOE Standard 3013-99 has been issued requiring the material to have less than $0.5 \%$ residual moisture. Current sampling techniques do not clearly demonstrate that PFP meets that standard.

Impact(s): There is a possibility that additional sampling and analysis or stabilization work would be required prior to acceptance of the material by Savannah River Site.

Corrective Action: Sampling, analysis, and data handling improvements will be put into place to allow demonstrated compliance with the standard. These improvements will be based upon established Data Quality Objectives and Quality Assurance requirements.

Lack of certified shipping containers in the DOE Complex to meet PFP schedules.

Impact(s): Prohibits shipment of nuclear materials that cannot go to either WIPP or DOT$6 \mathrm{M}$ containers (i.e., Pu standards for recertification, shipment of reactive materials for processing elsewhere, etc,)

Corrective Action: Work with the DOE Complex to certify containers to meet PFP shipping needs (i.e., 9975 container to be re-certified in Junc 2000, etc.).

Juistig resolve issues associated with precipitation process. Concentration, Density, Filtrate Handling (permitting of $241-Z$ to handle heavy metals), discard directly to tank farms.

Impact(s): Significantly impacts the number of containers to be stored under final disposition (approximately 1000 additional containers).

Corrective Action: Establish a team to develop a path forward to resolve these issues.

\section{COST VARIANCE ANALYSIS: $(+\$ 5.5 \mathrm{M})$}

\section{$\underline{\text { WBS/PBS }}$}

\subsection{0/TP05}

Description and $\mathrm{C}$ stabilization from current Vault Operations staff.

Impact: No impact.

Corrective Action: None required.

\subsection{1/TP05}

Maintain Safe \& Compliant PFP ,

Description and Cause: Underrun due to staff shortages and increased shift in support of stabilization from current base operations staff. 
Impact: No impact.

Corrective Action: None required.

\subsection{3/TP05 \\ Stabilization of Nuclear Materials at PFP}

Description and Cause: Positive cost variance is due to staff shortages, lag in contract costs and ahead of baseline schedule completion of Oxide Stabilization (140 items) with fewer resources as a result of increased charge size. Oxide stabilization will continue at an accelerated pace past completion of base and towards completion of stretch performance initiatives.

Impact: Lack of adequate staff could impact completion of reside stabilization and stretch performance initiative activities.

Corrective Action: Continue to place high priority on hiring, training, and clearing staff to support stretch stabilization performance initiative activities. Approve and implement baseline change requests pertaining to polycube stabilization and cementation. Initiate process to ensure contract costs are appropriately reflected.

\subsection{4/TP05 Disposition of Nuclear Materials}

Description and Cause: Underrun due primarily to lag in contract accruals.

Impact: No impact.

Corrective Action: None required.

\subsection{5/TP05 Transition PFP}

Description and Cause: Overrun due to higher than expected polychlorinated biphenyl (PCB) levels detected interfering with lab analyses of tank 241-Z-361 core samples. Presence of PCBs in tank 241-Z-361 may impact path forward disposition of tank.

Impact: Additional samples may be required to determine levels of PCBs in the tank and how to disposition its contents; may impact overall schedule and cost.

Corrective Action: Expecting to recover the delay in sample analysis progress in February, which will decrease the cost variance.

\subsection{2/TP05 PFP Fee Allocation}

Description and Cause: Unfavorable cost variance due to point adjustment in October $(<\$ 1,769 \mathrm{~K}>)$ to account for delay in staff hiring in FY 1999 impacting staff ramp up in FY 2000. Also the fee is being accrued at a rate of $100 \%$ which is higher than the budgeted rate.

Impact: No impact.

Corrective Action: None required.

\section{SCHEDUle VARIANCE ANALYSIS: $(-\$ 5.3)$}

\section{WBS/PBS}

1.4.5.1.14/TP05

\section{Title}

\section{Disposition of Nuclear Material}

Description and Cause: Vault modification construction not yet started. Waiting final determination from EIS Supplement Analysis (SA). Equipment procurements (gloveboxes, NDA lab equipment, and out can welder) have been delayed. Installation of support trailer, now 


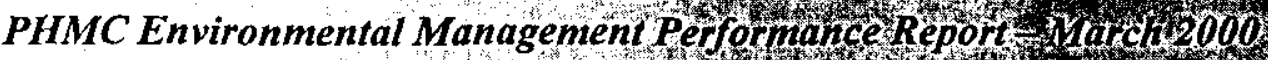

Section D: I-Nuclear Material Stabilization

planned to be ongoing, has been suspended as part of the DOE-HQ directed $5 \%$ funding reduction in

FY 2000.

Impact: May significantly impact startup of Bagless Transfer System at Hanford in October 2000. Corrective Action: Approve EIS Supplement Analysis or determine which portions of Project W460 are covered by the existing EIS and proceed on those areas.

\subsection{5/TP05 Transition PFP}

Description and Cause: Behind schedule due to late startup on core sample analyses at the 222-S Analytical Laboratory (not highest priority at the labs).

Impact: No Impact

Corrective Action: Expect to recover schedule on core sample analyses in February 2000.

Baseline Change Requests Currently in Process $(\$ 000)$

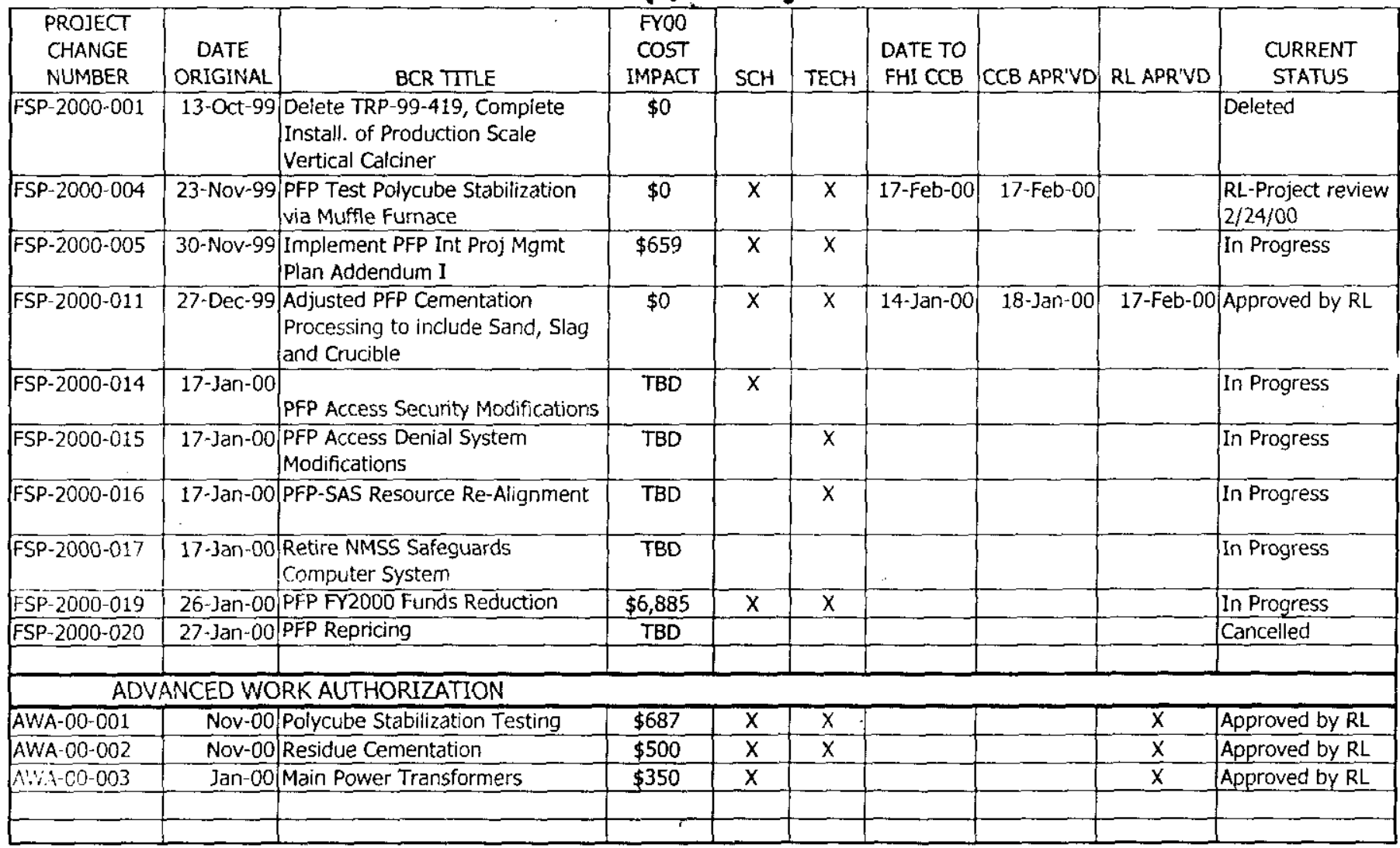




\section{Nuclear Materials Stabilization Project - WBS 1.4 .5 Milestone ACHIEVEMENT}

\begin{tabular}{|c|c|c|c|c|c|c|c|c|}
\hline \multirow[b]{2}{*}{ MILESTONE TYPE } & \multicolumn{4}{|c|}{ FISCAL YEAR-TO-DATE } & \multicolumn{3}{|c|}{ REMAINING SCHEDULED } & \multirow[b]{2}{*}{$\begin{array}{l}\text { TOTAL } \\
\text { FY } 2000\end{array}$} \\
\hline & $\begin{array}{c}\text { Completed } \\
\text { Early }\end{array}$ & $\begin{array}{c}\text { Completed } \\
\text { On } \\
\text { Schedule } \\
\end{array}$ & $\begin{array}{c}\text { Completed } \\
\text { Late }\end{array}$ & Overdue & $\begin{array}{c}\text { Forecast } \\
\text { Early }\end{array}$ & $\begin{array}{c}\text { Forecast } \\
\text { On } \\
\text { Schedule }\end{array}$ & $\begin{array}{c}\text { Forecast } \\
\text { Late }\end{array}$ & \\
\hline Enforceable Agreement & 1 & 0 & 0 & 0 & 0 & 1 & 0 & 2 \\
\hline DOE-HQ & 0 & 0 & 0 & 1 & 0 & 0 & 0 & 1 \\
\hline $\mathrm{RL}$ & 1 & 0 & 0 & 0 & 0 & 10 & 0 & 11 \\
\hline Total Project & 2 & 0 & 0 & 1 & 0 & 11 & 0 & 14 \\
\hline
\end{tabular}

Tri-Party Agreement / EA Milestones

Tri-Party Agreement Milestone M-15-37A (TRP-00-501), "Deliver Two (2)

Tank Z-361 Core Samples to 222-S", due 10/30/99

Green Completed 1 month early $(9 / 28 / 99)$

\section{DNFSB Commitments}

DNFSB Milestone IP-113 (TRP-00-500), "Install 2 LANL

Pyrolysis Units for Stabilization of Polycubes at PFP",

Green due $12 / 31 / 99$

- Alternative path forward using PFP muffle furnaces being evaluated. Thermal stabilization testing at Hanford's PNNL and PFP's PPSL underway consistent with approved AWA. Issued path forward recommendation to use direct thermal stabilization process versus pyrolysis.

- Letter issued to DOE-RL indicating milestone will not be met

\section{MILESTONE EXCEPTION REPORT}

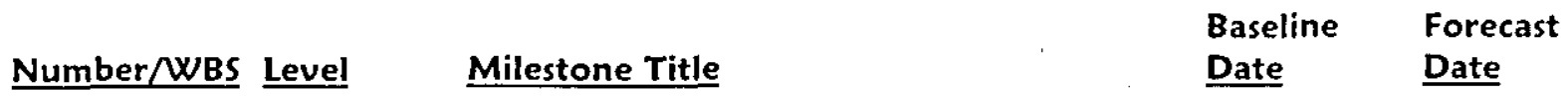

\section{OVERDUE - 1}

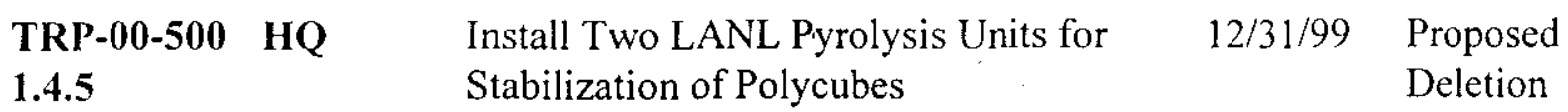

Cause: An alternative path forward using muffle furnaces for stabilization of polycubes has been recommended. A letter was issued to Department of Energy, Richland Office (DOE-RL) stating this Defense Nuclear Facility Safety Board milestone would not be met.

Corrective Action: Thermal stabilization testing at Hanford's Pacific Northwest National Laboratory and the Plutonium Finishing Plant's Plutonium Process Support Laboratories is underway with an approved Advance Work Authorization. A baseline change request has been prepared documenting this change in polycube stabilization methodology and is in the DOE-RL approval process. 


\section{FY 1999 OVERDUE - 2}
TRP-99-419 RL
Complete Installation of Production
09/30/99 Proposed
1.4.5
Scale Vertical Calciner
Deletion

Cause: The production scale vertical calciner has been replaced with the Magnesium Hydroxide

Precipitation process.

Impact: No impact. This milestone is obsolete.

Corrective Action: Since installation and testing of the production scale vertical calciner is an EM65 Management Commitment, the Department of Energy, Richland Office (DOE-RL) change control process cannot remove this milestone.
TRP-99-500 HQ
Complete Installation \& Testing of
$09 / 30 / 99$
Proposed
1.4.5
Production Vertical Calciner
Deletion

Cause: The production scale vertical calciner has been replaced with the Magnesium Hydroxide Precipitation process.

Impact: No impact. This milestone is obsolete.

Corrective Action: Since this milestone is a DOE-HQ milestone and is part of the DOE-HQ 1998 DNFSB Recommendation 94-1 Implementation Plan, the Department of Energy, Richland Office change control process cannot remove this milestone. However, this milestone will be removed upon approval of the revised DOE-HQ DNFSB Recommendation 94-1 Implementation Plan in carly FY 2000.

\section{Performance Objectives}

\section{Oxides/Metals/Polycubes Stabilization}

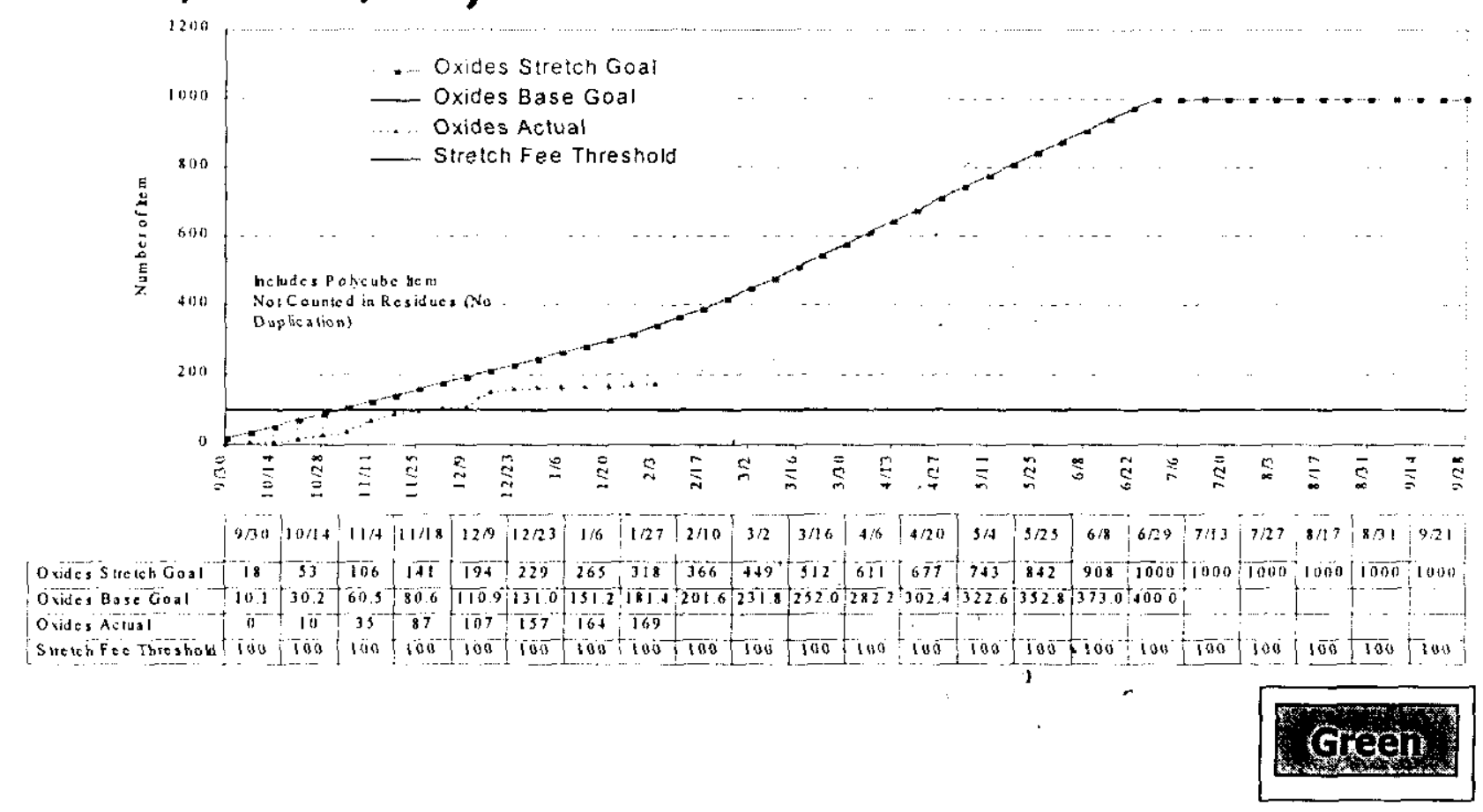




\section{SOLUTION STABILIZATION}

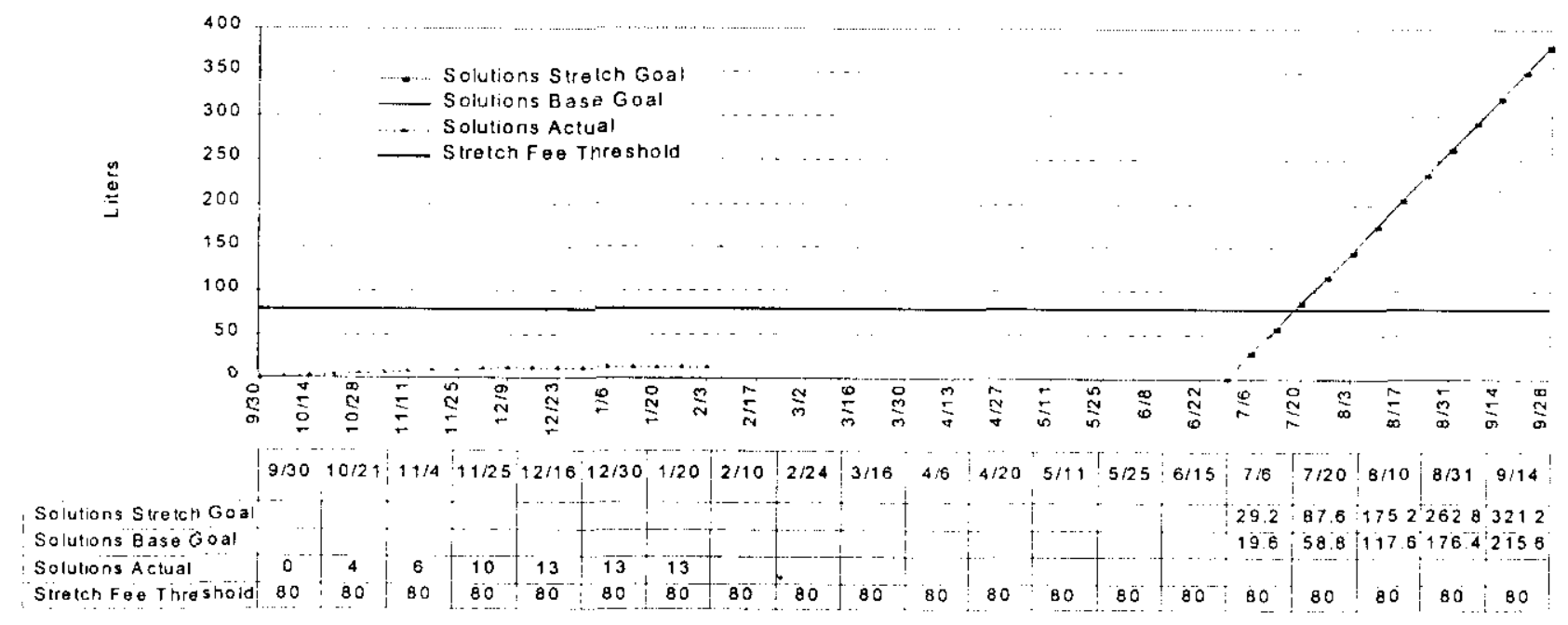

Aggressively pursuing construction completion in support of stabilization activities. Yellow

\section{RESIDUES STABILIZATION}

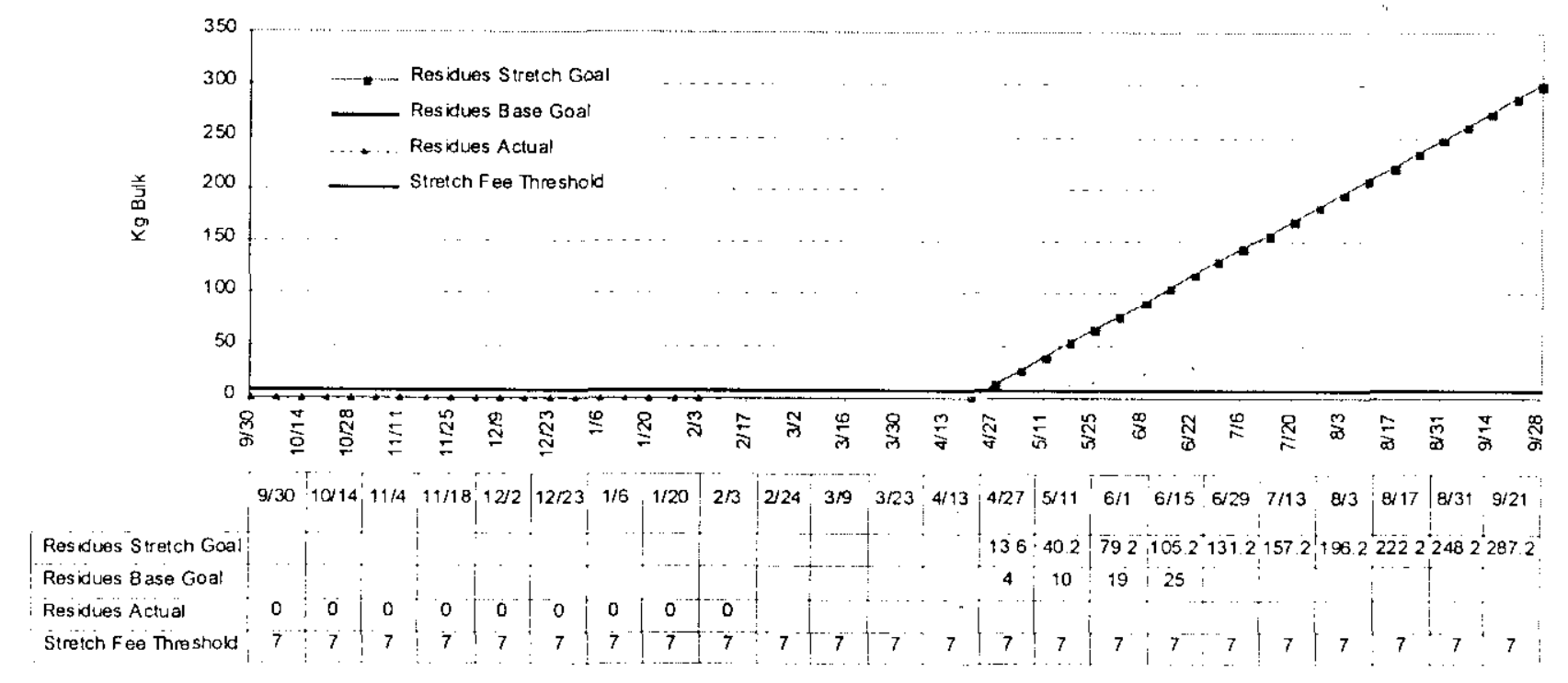

Currently working Central Waste Complex / WIPP Acceptance and RCRA permitting issues.

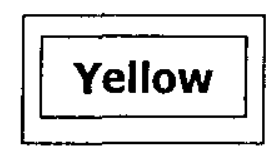

\section{KEY INTEGRATION ACTIVITIES}

- Continue working with PNNL on activities associated with the $\mathrm{Mg}(\mathrm{OH})_{2}$ process and polycube stabilization issues

- Continue discussions with Waste Management regarding Waste Isolation Pilot Program certification 

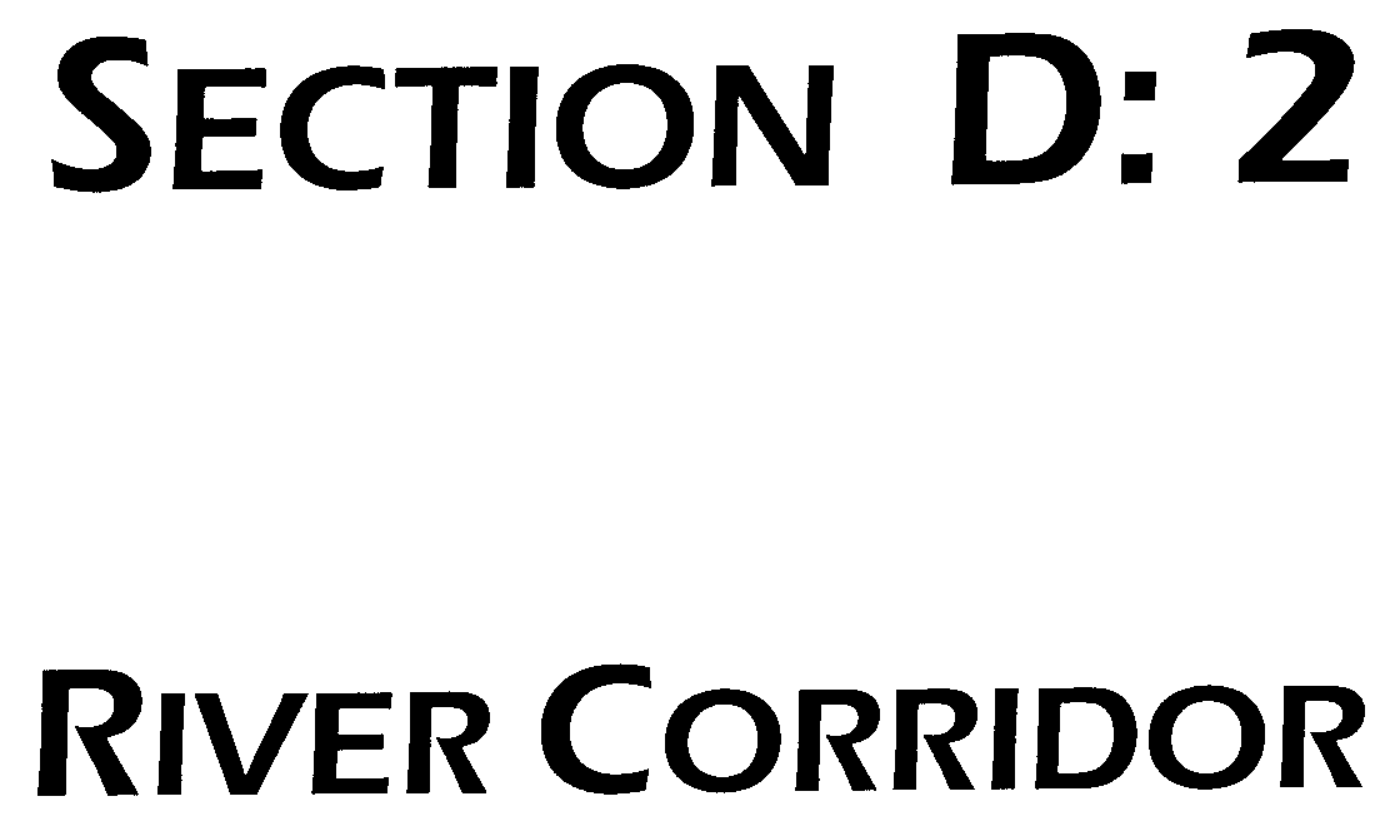

PROJECT MANAGERS

\author{
P. M. Knollmeyer, RL \\ Phone: (509) 376-7435
}

N. Boyter, FH
Phone: (509) 373-3725

DOE/RL-99-83, Rev. 2 


\section{SUMMARY}

The River Corridor Project consists of the following projects: 300 Area Liquid Effluent Facility (LEF) WBS 1.2.3.2, Project Baseline Summary (PBS) WM05; B-Plant, WBS 1.4.1, PBS TP01; 300 Area/Special Nuclear Materials, WBS 1.4.4, PBS TP04; Transition Project Management, WBS 1.4.6, PBS TP12; Accelerated Deactivation, WBS 1.4.8, PBS TP10; 324/327 Facility Transition, WBS 1.4.10, PBS TP08; and Hanford Surplus Facility Program (300 Area Revitalization), WBS 1.4.11, PBS TP14.

PBS WM05 is divided between WBS 1.2.3.1, Liquid Effluents (200 LEF) and WBS 1.2.3.2, 310 TEDF/340 Facility (300 LEF). The 310 TEDF/340 Facility work scope is now included in the River Corridor Project, whereas the Liquid Effluents (200 LEF) work scope has remained in Waste Management. For the purpose of performance analysis, PBS WM05 is reported in Waste Management, which has the majority of the work scope and funding incorporated in their baseline.

NOTE: Unless otherwise noted, the Safety, Conduct of Operations, and Cost/Schedule data contained herein is as of January 31, 2000. All other information is as of March 1, 2000.

Good progress was made toward closeout of the actions required by the B Plant transfer Memorandum of Agreement (MOA). The transfer activities included completing the changeout of the ACT-02 HEPA filter and pre-filter replacements. However, a crack was discovered on the newly replaced W-059 ducting. A revised test plan is being prepared by Fluor Federal Services (FFS) to include contracting a specialist in fan and duct failures to assist in identifying the cause of the low flow condition failure. The impact of this defect is a delay in completion of the MOA activities by at least one month.

The final report of the 300 Area Waste Acid Treatment System (WATS) Resource Conservation and Recovery Act (RCRA) closure activities due March 31, 2000 will be delayed. This report must include information obtained after the Washington State Department of Ecology (WDOE) approves the Hanford Site RCRA permit which also includes the WATS permit. WDOE approval is not expected until later this spring, consequently delaying the final report submittal until September 2000.

The Accelerated Deactivation project is making good progress in planning for the disposition of approximately 1,865 metric tons (MT) of Hanford Unirradiated Uranium. A public meeting was held in Portsmouth, Ohio to discuss public comments on the Environmental Assessment (EA) and an additional meeting was held with the Portsmouth Department of Energy (DOE) to discuss transportation, unloading and storage requirements at Portsmouth, focussing on the most costeffective options to minimize project cost. A proposal to use Conex Boxes, also known as Sealand Containers, for transportation and storage was positively received. This option would minimize handling cost and eliminate building modification costs at Portsmouth. The cost reduction could approach $\$ 1$ million. Other progress included the approval of the Uranium Disposition Project Management Plan. Additionally, a Uranium Disposition Alternatives workshop held in mid January identified $\mathrm{UO}_{3}$ powder as the only Unirridiated Uranium (UU) with market resale potential. 


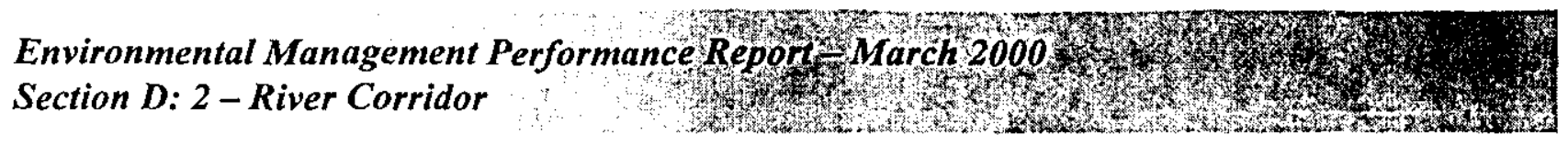

The National Facility Deactivation Initiative (NFDI) team continues to participate in several multi-DOE site activities. Most recently the team kicked off NFDI assistance at the Savannah River Site (SRS) for the deactivation of F Canyon, assisted in the end point development at Oak Ridge Y12 9201-5, completed development of POWERtool work libraries for the Nevada Test Site and completed a portion of the POWERtool implementation at Idaho National Engineering and Environmental Laboratory (INEEL) surplus facilities.

The $324 / 327$ Buildings Stabilization/Deactivation Project Management Plan (PMP), Rev. 3 was completed in January. Permission was granted to implement the revised PMP which re-

sequences critical path activities to support TPA milestone M-89-02 "Complete Removal of 324 Building Radiochemical Engineering Cell (REC) B Cell Mixed Waste (MW) and Equipment" while the baseline change request (BCR) FSP-2000-013 was processed through the approval cycle (approved February 24, 2000). During the period, repairs to the B Cell crane door were completed. All $\mathrm{B}$ Cell low-level waste was removed and mixed waste consolidated into one box. While efforts continue to focus on restoration of A Cell for grout container storage, initial dose profiling on the B Cell grout containers were completed. Verification activities on eleven grout containers were also completed and accepted by Waste Management personnel.

Acceleration of deactivation at the 327 Facility made good progress in January. Transfer of forty specimen containers from dry storage was completed. To date, sixty-nine specimen containers out of approximately 300 planned have been transferred. In addition, packaging of 10.8 cubic meters $\left(\mathrm{m}^{3}\right)$ of bulk waste into boxes was completed, bringing the total packaged to date to 24.7 $\mathrm{m}^{3}$ out of approximately $30 \mathrm{~m}^{3}$ planned for the year.

Fiscal-year-to-date milestone performance (EA, DOE-HQ, and RL) shows that one of six milestones (17 percent) was completed on or ahead of schedule and five milestones ( 83 percent) are overdue. The Milestone Achievement details, found following cost and schedule variance analysis, provide further information on all milestone types.

\section{ACCOMPLISHMENTS}

- Approved the Uranium Disposition Project Management Plan.

- $\quad$ Completed development of POWERtool work libraries for the Nevada Test Site.

- Initiated POWERtool implementation at INEEL.

- $\quad$ Completed and implemented the 324/327 PMP, Rev 3.

- Completed B Cell crane door repairs.

- Completed removal of all B Cell low-level waste; consolidated mixed waste into one box.

- Completed B Cell grout container initial dose profiling and initiated waste portfolios.

- Completed verification activities on eleven Rack 1 A grout containers.

- $\quad$ Completed transfer of 40 specimen containers from the 327 Facility dry storage; 69 transfers out of $\sim 300$ planned completed to date.

- $\quad$ Completed packaging $10.8 \mathrm{~m}^{3}$ bulk waste from 327 Facility into waste boxes; $24.7 \mathrm{~m}^{3}$ of bulk waste packaged out of $\sim 30 \mathrm{~m}^{3}$ planned for the year.

- Issued the Uranium Disposition Environmental Analysis for public comment. 


\section{SAFETY}
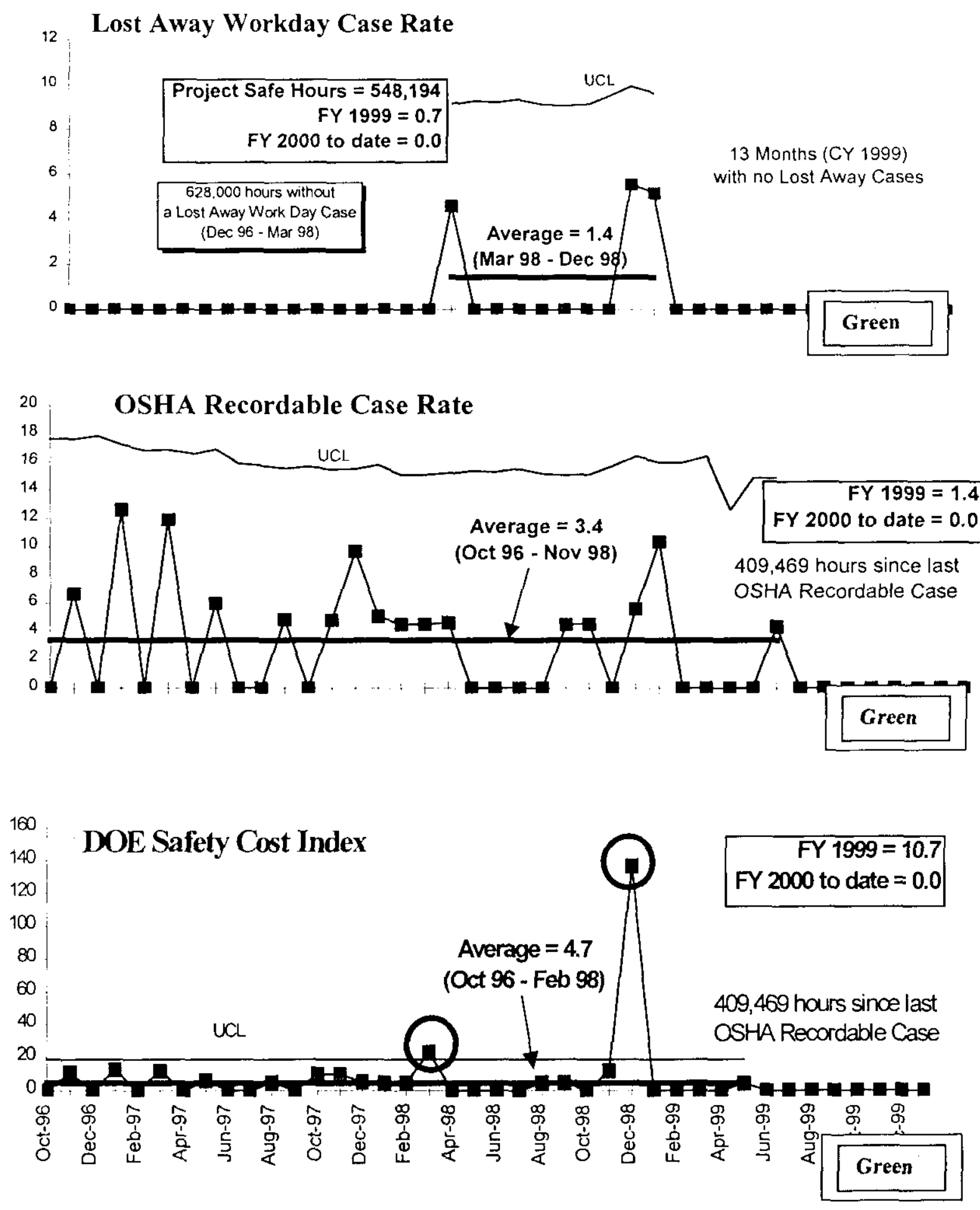


\section{CONDUCT OF OPERATIONS / ISMS STATUS}

\section{Conduct of Operations Event Index}

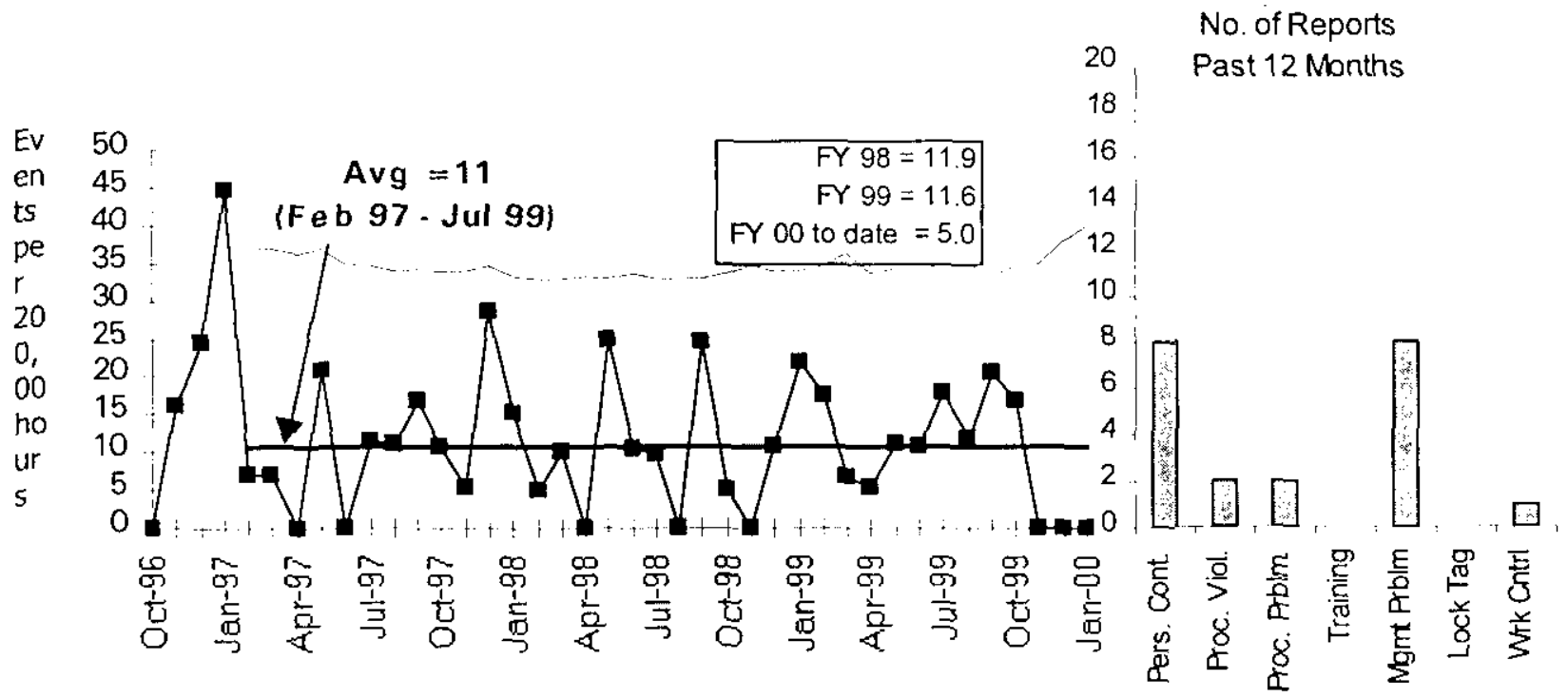

The average River Corridor ConOps incidence of events rate is slightly higher than the overall PHMC average incidence of events rate.

\section{ISMS STATUS}

- $\quad$ RCP ISMS Implementation Plan completed

- $\quad$ Activity Level Survey completed

- Analysis, feedback and actions in progress

- $\quad$ ISMS Internal Readiness Review Plan (IRR) on schedule for completion by February 18

- Senior Management Review Board members identified

- $\quad$ RCP ISMS System Description in progress

- Automated Job Hazard Analysis (AJHA) implementation at each RCP facility in progress

- ISMS Verification on schedule for May 2000 


\section{BREAKTHROUGHS / OPPORTUNITIES FOR IMPROVEMENT}

\section{BREAKTHROUGHS}

- Final disposition of Unirridiated Uranium fuel elements to low-level waste burial grounds vs. packaging and transportation to Portsmouth, Ohio for interim storage will save in excess of $\$ 1 \mathrm{M}$.

- Consolidating shipments of Uranium billets and Uranium Oxide powder will save approximately $40 \%(\$ 200 \mathrm{~K})$ off the planned transportation cost to Portsmouth, Ohio.

\section{OPPORTUNITIES FOR IMPROVEMENT}

- 324 Project Planning / Execution: Need to continue emphasis on improved schedule management to ensure that critical path negative float is recovered to positive float. Current actions are directed at organization shift to projects and improving crane availability.

\section{UPCOMING ACTIVITIES}

- B Plant MOA -- Complete all closeout activities by March 2000.

- Integrated Environmental, Safety \& Health System (ISMS) -- Complete verification activities by May 15,2000 .

- 300 Area Waste Acid Treatment System (WATS) Resource Conservation and Recovery Act (RCRA) Closure Activities ---Issue the final report for the 300 Area WATS by September 2000. The revised date allows adequate time for the WDOE review and comment cycle.

- $\quad$ TPA Milestone M-89-02-- Complete Removal of 324 Building REC B Cell MW \& Equipment by November 2000

\section{Cost Performance (\$M):}

\begin{tabular}{|l|c|c|c|}
\hline & BCWP & ACWP & VARIANCE \\
\hline River Corridor Project & $\$ 16.6$ & $\$ 16.5$ & $+\$ 0.1$ \\
\hline
\end{tabular}

The $\$ 0.1$ million (0.6 percent) favorable cost variance is within the established threshold. Further information at the PBS level can be found in the following Cost Variance Analysis details. 


\section{SChedule Performance ( $\$ M)$ :}

\begin{tabular}{|l|c|c|c|}
\hline & BCWP & BCWS & VARIANCE \\
\hline River Corridor Project & $\$ 16.6$ & $\$ 16.8$ & $-\$ 0.2$ \\
\hline
\end{tabular}

The $\$ 0.2$ million (1.2 percent) unfavorable schedule variance is within the established threshold. Further information at the PBS level can be found in the following Schedule Variance Analysis details.

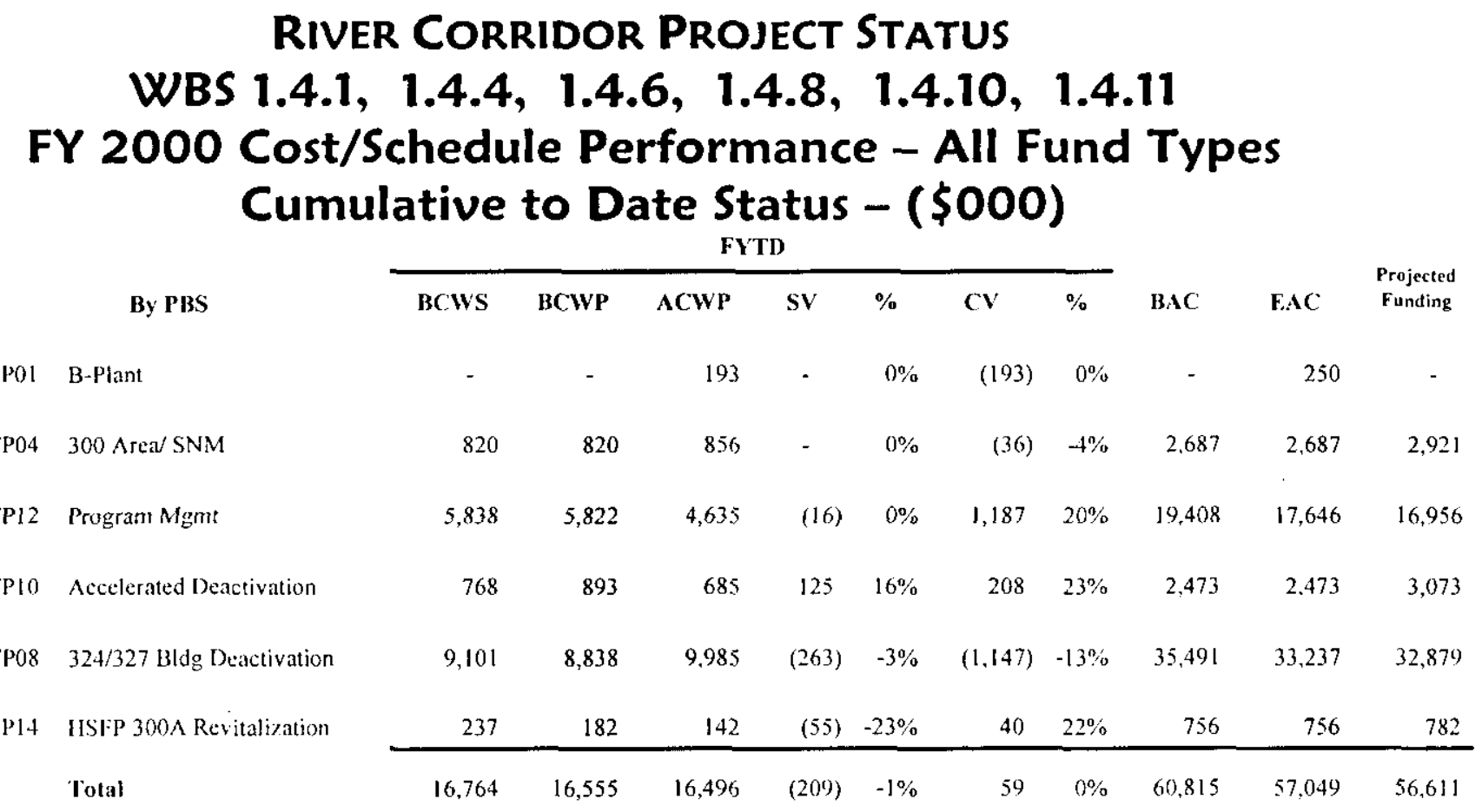

Note: 324/327 reflects PMP Rev. 3 implementation. 


\section{COST / SChedule PerformanCe INDices \\ (JANUARY 2000 AND FYTD)}

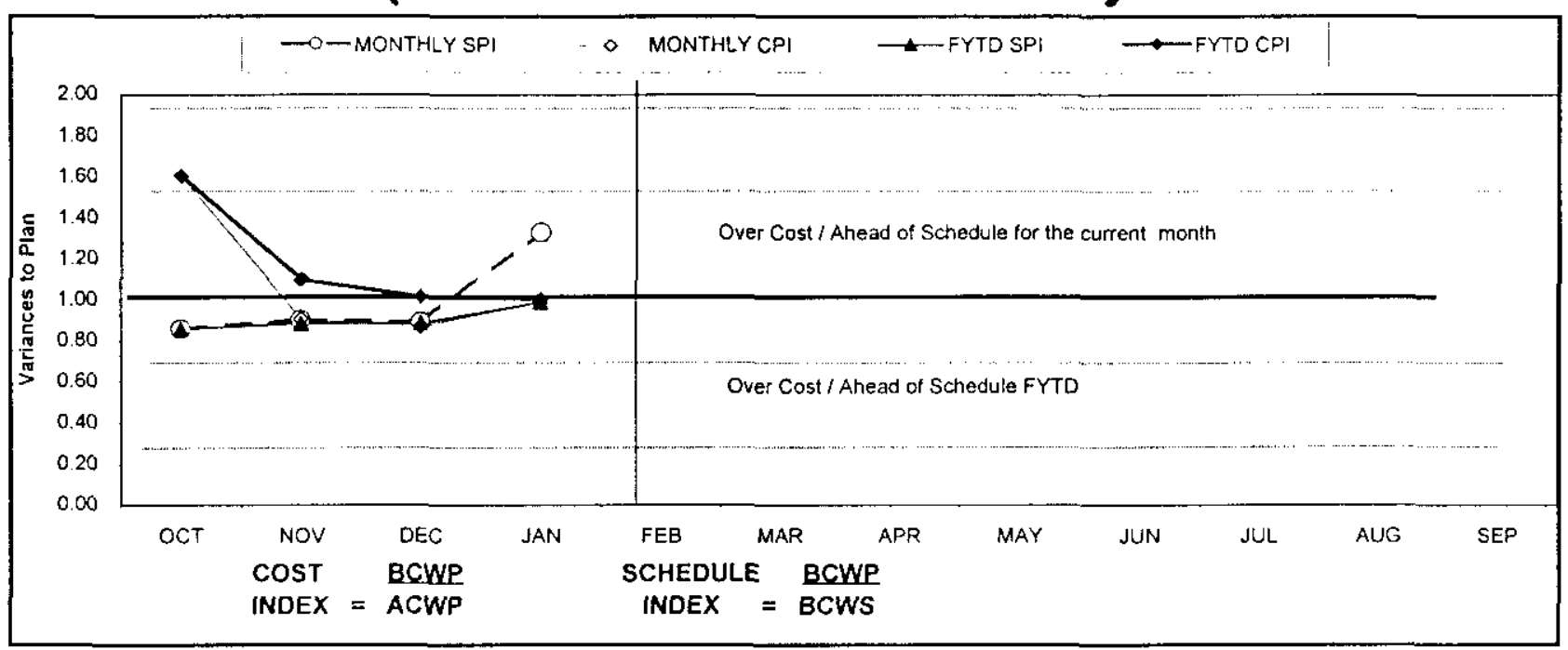

\begin{tabular}{|c|c|c|c|c|c|c|c|c|c|c|c|c|}
\hline FY 2000 & OCT & NOV & DEC & JAN & FEB & MAR & APR & MAY & JUN & JUL & AUG & SEP \\
\hline MONTHLY SPI & 0.86 & 0.90 & 0.89 & 1.33 & & & & & & & & \\
\hline MONTHLY CPI & 160 & 0.90 & 0.87 & 0.98 & & & & & & & & \\
\hline FYTD SPI & 0.86 & 0.88 & 0.89 & 0.99 & & & & & & & & \\
\hline FYTD CPI & 1.60 & 1.10 & 1.01 & 1.00 & & & & & & & & \\
\hline MONTHLY BCWS & $\$ 3,652$ & $\$ 5,162$ & $\$ 4,092$ & $\$ 3,858$ & & & & & & & & \\
\hline MONTHLY BCWP & $\$ 3,134$ & $\$ 4,650$ & $\$ 3,647$ & $\$ 5,124$ & & & & & & & & \\
\hline MONTHLY ACWP & $\$ 1,954$ & $\$ 5,141$ & $\$ 4,195$ & $\$ 5.206$ & & & & & & & & \\
\hline FYTD BCWS & $\$ 3,652$ & $\$ 8,814$ & $\$ 12,906$ & $\$ 16.764$ & & & & & & & & \\
\hline FYTD BCWP & $\$ 3,134$ & $\$ 7,784$ & $\$ 11.431$ & $\$ 16.555$ & & & & & & & & \\
\hline FYTD ACWP & $\$ 1,954$ & $\$ 7,095$ & $\$ 11,290$ & $\$ 16.496$ & & & & & & & & \\
\hline
\end{tabular}

\section{ISSUES}

\section{TECHNICAL ISSUES}

Issue: Downtime driven by equipment failure (A Cell crane) continues to create delays in the 324 Facility project schedules.

Impact: The ongoing crane failures have caused a day for day slip in operational activities.

Corrective Action: The A Cell crane has been returned to limited service while procurement activities associated with repair are expedited. Additionally, the in-cell shuttle box segregation was accelerated from the July time frame and the implementation of the revised PMP has resulted in some schedule recovery.

Issue: The 324 Building Fire Hazards Analysis (FHA) revision supporting the 324 Building Safety Analysis Report (SAR) update resulted in lower combustible load limits.

Impact: There is a potential adverse cost impact to work progress at the 324 Building. Corrective Action: An implementation plan that allows work to continue and maintain revised combustible load limits or invoking compensatory measures has been developed. Evaluation of alternative fire suppression capabilities to allow increase in combustible load limits continues. 
Issue: A crack was discovered on the new B Plant W-059 Duct Replacement.

Impact: Additional time and effort is required to analyze failure mode and develop corrective actions, further delaying completion of B Plant turnover MOA.

Corrective Action: Fluor Federal Services has retained a consultant to evaluate and determine the cause. Repair and test damaged section of ventilation duct.

\section{DOE/REGULATOR/EXTERNAL ISSUES}

Issue: Approval by the U.S. Department of Energy - Headquarters (DOE-HQ) of the Unirradiated Uranium (UU) billet Safety Analysis Report for Packaging (SARP) is required by May 31, 2000. Performance Initiatives encourage the accelerated disposition of this material, however, review and approval time frames do not support attempts to accelerate shipments.

Impact: Failure to gain approval on or before May 31, 2000 will jeopardize the combined shipment of UU billets and T-Hoppers, thus losing the opportunity to save approximately $\$ 200,000$ in FY 2000. Performance Incentive RC3-SS Uranium Disposition will be impacted by the inability to ship billets and T-Hoppers in FY 2000. Corrective Action: A revision to the SARP, which limits the amount of criticality analysis, may expedite the review process. Timely DOE-HQ review and approval of billet Safety Analysis Report for Packaging (SARP) is critical for Disposition.

\section{Cost VARIANCE ANAlysis: (+\$0.1)}

$\frac{\text { WBS/PBS }}{\text { 1.4.1/TP01 }} \quad \frac{\text { Title }}{\text { B Plant }}$

Description and Cause: The unfavorable cost variance is due to unplanned costs associated with the ventilation filter change outs and ductwork repairs.

Impact: Deprives other projects of funding for current year priorities including accelerated deactivation activities.

Corrective Action: Work scope is being performed via an approved Advanced Work Authorization (AWA) while BCR FSP-00-008, which funds the B Plant action items, is dispositioned.

\subsection{6/TP12 Transition Project Management}

Description and Cause: The favorable cost variance is primarily due to the PHMC restructuring which has mapped personnel to other sub-projects, resulting in underruns in labor and contractor support. Other sub-projects are experiencing unfavorable cost variances due to the influx of unplanned personnel from PBS TP12.

Impact: Not determined. Underruns have been utilized to fund other high priority project and FY 1999 carryover work scope.

Corrective Action: Re-planning of this account is underway to reflect the new structure, including the transfer of funds to other PHMC sub-projects where former Facility Stabilization personnel have been mapped.

\subsubsection{0/TP08 324/327 Building Deactivation}

Description and Cause: The unfavorable cost variance is primarily due to performance of unfunded accelerated 327 Building deactivation work scope via AWA (super stretch performance 
incentive).

Impact: None. Spending against AWAs is being closely monitored.

Corrective Action: Costs of work being performed via AWA will be measured against baseline performance once the applicable baseline change requests are approved.

\subsubsection{1/TP14 HSFP 300 Area Revitalization}

Description and Cause: The favorable cost variance is primarily due to less than planned costs in Min Safe surveillance and corrective maintenance activities.

Impact: None.

Corrective Action: Funds made available via underruns will be utilized toward achievement of accelerated deactivation activities.

All other PBS variances are within established thresholds.

\section{SCHEDUle VARIANCE ANALYSIS: (-\$0.2)}

\section{WBS/PBS}

\section{$1.4,11 / \mathrm{TP} 14$}

Description and Cause: The unfavorable schedule variance is due to delays in performing the baseline estimate update activities. Changes in organization associated with the PHMC restructuring have caused the delay as a result of personnel performing other planned work either within sub-project or other areas.

Impact: Will not complete the estimate update in first quarter as planned.

Corrective Action: Estimating activities will be included in the development of the 300 Area

Accelerated Closure Plan.

All other PBS variances are within established thresholds.

\section{Baseline Change Requests Currently in Process (\$000)}

\begin{tabular}{|c|c|c|c|c|c|c|c|c|c|}
\hline $\begin{array}{l}\text { PROIECT } \\
\text { CHANGE } \\
\text { NMEER }\end{array}$ & $\begin{array}{l}\text { DATE } \\
\text { ORIGIN }\end{array}$ & BCR TILE & $\begin{array}{l}\text { FYO COST } \\
\text { IMPACT }\end{array}$ & $\mathrm{SCH}$ & TECH & $\begin{array}{c}\text { DATE } \\
\text { TOCCB }\end{array}$ & $\begin{array}{c}\text { OCB } \\
\text { ADRVDO }\end{array}$ & $\frac{\mathrm{RA}}{\mathrm{APR}}$ & $\begin{array}{l}\text { CUPRENT } \\
\text { STATUS }\end{array}$ \\
\hline 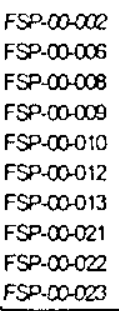 & $\begin{array}{c}11 / 299 \\
12 / 1 / 99 \\
123 / 99 \\
129190 \\
12 / 15 / 99 \\
1 / 3100 \\
1 / 11 / \infty 0 \\
1 / 27 / 00 \\
1 / 31 / 00 \\
2 / 600\end{array}$ & 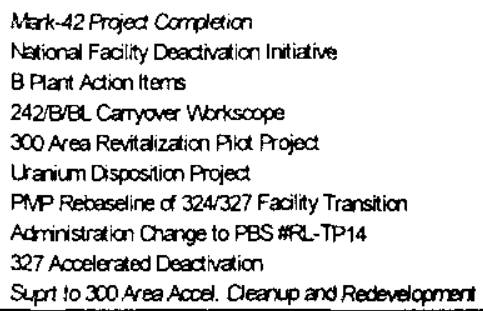 & $\begin{array}{l}\$ 296 \\
\$ 545 \\
\$ 358 \\
\$ 36 \\
\$ 26 \\
\$ 234 \\
\$ 2,620 \\
\$ 92 \\
\$ 0 \\
\$ 520\end{array}$ & $\begin{array}{l}x \\
x \\
x\end{array}$ & $\begin{array}{l}x \\
x \\
x \\
x \\
x \\
x \\
x\end{array}$ & $\begin{array}{l}01 / 1400 \\
01 / 1400 \\
\text { NA } \\
0100 \times \infty \\
01 / 1900\end{array}$ & $\begin{array}{l}01 / 1900 \\
\text { NA } \\
\text { CO/07/00 } \\
01 / 1900\end{array}$ & $\begin{array}{l}\text { NA } \\
\text { NA } \\
\text { NA }\end{array}$ & $\begin{array}{l}\text { Under revision } \\
\text { Under revision } \\
\text { Board question on funding } \\
\text { Approved \& project level } \\
\text { In RL review cycle } \\
\text { In review cycle } \\
\text { In review cyde } \\
\text { in review cyde }\end{array}$ \\
\hline \multicolumn{10}{|c|}{ AOVANCE WORK AUTHORIZATIONS } \\
\hline $\begin{array}{l}\text { AWA } \\
\text { AWA } \\
\text { AWA } \\
\text { AWA } \\
\text { AWA } \\
\text { AWA }\end{array}$ & $\begin{array}{l}101 / 99 \\
1018 / 99 \\
11 / 18199 \\
11 / 2299 \\
11 / 2299 \\
11 / 22 / 99\end{array}$ & $\begin{array}{l}327 \text { Stabilization Deactivation Projed } \\
\text { Beryllium Sampling } \\
\text { PNN Legacy Weste \& A Cell Clean-at } \\
\text { B Plant Filker Changeat } \\
324 \text { Bilding B Cell Cleanout } \\
324 \text { Tank } 105 \text { Inspection }\end{array}$ & $\begin{array}{l}\$ 1,500 \\
\$ 20 \\
\$ 66 \\
\$ 150 \\
\$ 650 \\
\$ 15\end{array}$ & $x$ & $\begin{array}{l}x \\
x \\
x \\
x \\
x \\
x\end{array}$ & & & $\begin{array}{l}0207 / \infty 0 \\
11 / 01 / 99 \\
11 / 1999 \\
11 / 24 / 99 \\
11 / 2400 \\
11 / 24 / 99\end{array}$ & 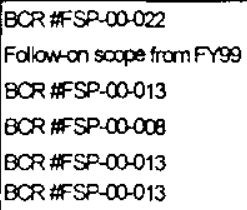 \\
\hline
\end{tabular}


RIVER CORRIDOR

Milestone ACHIEVEMENT

\begin{tabular}{|c|c|c|c|c|c|c|c|c|}
\hline \multirow[b]{2}{*}{ MILESTONE TYPE } & \multicolumn{4}{|c|}{ FISCAL YEAR-TO-DATE } & \multicolumn{3}{|c|}{ REMAINING SCHEDULED } & \multirow[b]{2}{*}{$\begin{array}{c}\text { TOTAL } \\
\text { FY } \\
2000\end{array}$} \\
\hline & $\begin{array}{c}\text { Completed } \\
\text { Early }\end{array}$ & $\begin{array}{c}\text { Completed On } \\
\text { Schedule }\end{array}$ & $\begin{array}{l}\text { Completed } \\
\text { Late }\end{array}$ & Overdue & $\begin{array}{c}\text { Forecast } \\
\text { Early }\end{array}$ & $\begin{array}{l}\text { Forecast } \\
\text { On } \\
\text { Schedule }\end{array}$ & $\begin{array}{c}\text { Forecast } \\
\text { Late }\end{array}$ & \\
\hline Enforceable Agreement & 1 & 0 & 0 & 0 & 0 & 0 & 0 & 1 \\
\hline DOE-HQ & 0 & 0 & 0 & 0 & 0 & 0 & 0 & 0 \\
\hline $\mathrm{RL}$ & 0 & 0 & 0 & 5 & 0 & 1 & 4 & 10 \\
\hline Total Project & 11 & 0 & 0 & 5 & 0 & 1 & 4 & 11 \\
\hline
\end{tabular}

Note: Does not reflect 324/327 PMP Rev 3 implementation.

M-092-13 (TRP-00-902), " Submit 300 Area SCW Project Management Plan," due 9/29/00 -- Completed 10 months early (11/30/99)

M-89-02 (TRP-99-901), Complete Removal of 324 Building Radiochemical Engineering Cells (REC) B Cell Mixed Waste (MW) and Equipment," due 11/30/00 -.- 9 days behind critical path schedule. Day for-day slip caused by A-Cell crane failure. Corrective actions are being taken to recover the schedule (eg., expediting A-Cell crane repair procurement activities, putting the $A$ Cell Crane back into limited service, accelerating the in-cell shuttle box segregation from July, etc.)

\section{DNFSB Commitments}

Nothing to report.

\section{MILESTONE EXCEPTION REPORT}

\section{OVERDUE - 5}

TRP-98-936 RL Complete 2A Rack Size Reduction $\quad 10 / 23 / 99 \quad 04 / 30 / 00$

\section{4 .10 \\ and Removal}

Cause: Building systems, including facility cranes, are not operating in a manner that allows progress on project schedules.

Impact: No impact. This work scope has been re-sequenced as part of the revised PMP implementation.

Corrective Action: Although implementation of the revised PMP which re-sequenced critical path activities has occurred, the milestone date cannot be revised until BCR FSP-00-013 is approved. 
TRP-99-907 RL Complete 1A Rack 382-B Cask Shipments 01/01/00 05/30/00

\subsubsection{0}

Cause: Building systems, including facility cranes, are not operating in a manner that allows progress on project schedules.

Impact: No impact. This work scope has been re-sequenced as part of the revised PMP implementation.

Corrective Action: Although implementation of the revised PMP which re-sequenced critical path activities has occurred, the milestone date cannot be revised until BCR FSP-00-013 is approved

TRP-99-910 RL Complete transfer of SNF from B Cell 01/11/00 Proposed

\subsubsection{0}

Deletion

Cause: The decreased availability of the facility cranes and delay in grout container characterization activities resulted in work scope delays.

Impact: Minimal impact. Not on TPA M-89-02 critical path.

Corrective Action: This milestone will be deleted upon the approval of BCR FSP-00-013.

$\begin{array}{llll}\text { TRP-99-933 RL Complete Containerization of Dispersible } & 11 / 06 / 99 & 04 / 30 / 00\end{array}$

\subsubsection{0 under 2A Rack}

Cause: Building systems, including facility cranes, are not operating in a manner that allows progress on project schedules.

Impact: No impact. This work scope has been re-sequenced as part of the revised PMP implementation.

Corrective Action: Although implementation of the revised PMP which re-sequenced critical path activities has occurred, the milestone date cannot be revised until BCR FSP-00-013 is approved.

$\begin{array}{llll}\text { TRP-99-945 RL } & \begin{array}{l}\text { Complete shipment of one RH-TRU } \\ \text { Grout Container }\end{array} & 01 / 13 / 00 & \begin{array}{l}\text { Proposed } \\ \text { Deletion }\end{array}\end{array}$

Cause: The decreased availability of the facility cranes and delay in grout container characterization activities resulted in work scope delays.

Impact: Minimal/None.

Corrective Action: This milestone will be deleted upon approval of BCR FSP-00-013.

\section{FORECAST LATE - 4}

TRP-99-909 RL Complete 2A Rack 382-B Cask Shipments 03/29/00 02/28/01

\section{4 .10}

Cause: Building systems, including facility cranes, are not operating in a manner that allows progress on project schedules.

Impact: No impact. This work scope has been re-sequenced as part of the revised PMP implementation.

Corrective Action: Although implementation of the revised PMP which re-sequenced critical path activities has occurred, the milestone date cannot be revised until BCR FSP-00-013 is approved 
TRP-00-914 RL

\subsubsection{0}

PUREX Tunnels Ready to Receive

B Cell MW/SCW
04/20/00 Proposed

Deletion

Cause: Revision to the Special Case Waste Study, completed in September 1999, determined waste shipments to Central Waste Complex (CWC) were a better option than the Purex tunnels. Impact: No impact. Work no longer planned for tunnel disposition.

Corrective Action: This milestone will be deleted upon approval of BCR FSP-00-013.

TRP-00-915 RL Complete the 324 LWHS Design \& $\quad 06 / 30 / 00 \quad 09 / 30 / 03$

\subsubsection{Construction}

Cause: Delays in design approval driven by need for additional characterization of the physical, installed transfer systems that will interface with LWHS.

Impact: No impact. This work scope has been re-sequenced as part of the revised PMP implementation.

Corrective Action: This activity will be performed in a different sequence than currently planned in support of final deactivation. The milestone date will be revised upon approval of BCR FSP-00-013.

TRP-00-931 RL Complete SCW Shipments to Storage $\quad 09 / 29 / 00 \quad 11 / 30 / 00$ 1.4.10

Cause: Building systems, including facility cranes, are not operating in a manner that allows progress on project schedules. Cranes are required to package, characterize and move waste containers.

Impact: No impact. This work scope has been re-sequenced as part of the revised PMP implementation.

Corrective Action: The milestone date will be revised upon approval of BCR FSP-00-013.

\section{FY 1999 OVERDUE - 1}

TRP-99-937 RL

1.4.10
Remove, Package \& Ship Excess

Equipment from B Cell
09/30/99 Proposed

Deletion

Cause: The work scope related to this milestone was included in the $324 \mathrm{~B}$ Cell Cleanout work scope reconfiguration per approved BCR FSP-99-017. The milestone should have been deleted with the approval of FSP-99-017 but was overlooked.

Impact: None. This milestone is obsolete.

Corrective Action: This milestone will be deleted upon approval of BCR FSP-00-013. 


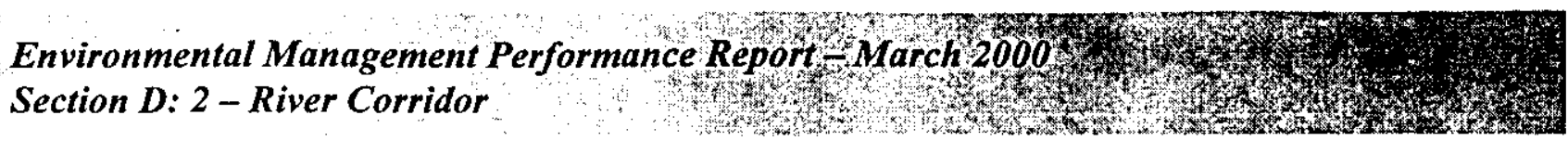

Performance Objectives

\begin{tabular}{|c|c|c|}
\hline Outcome & $\begin{array}{l}\text { Performance } \\
\text { Indicator }\end{array}$ & Status \\
\hline \multirow{3}{*}{$\begin{array}{l}\text { Restore the } \\
\text { River Corridor } \\
\text { for Multiple } \\
\text { Uses }\end{array}$} & $\begin{array}{l}\text { Accelerate } 324 / 327 \\
\text { Deactivation }\end{array}$ & $\begin{array}{l}\text { Baseline work projected to be complete per PI requirements; less than a } 50 \% \\
\text { probability that stretch will be completed per PI requirements. }\end{array}$ \\
\hline & $\begin{array}{l}\text { Continue Acceleration } \\
\text { of } 324 / 327 \\
\text { Deactivation }\end{array}$ & $\begin{array}{l}\text { Good progress is being made in cleanout and packaging of legacy waste. } \\
\text { However, lack of confirmed funding for this effort jeopardizes completion of } \\
\text { these activities (via approved AWA). The } 327 \text { Facility has developed a plan } \\
\text { to reduce MinSafe costs to cover a portion of this work scope while efforts to } \\
\text { identify remaining funds continue. }\end{array}$ \\
\hline & Disposition Uranium & $\begin{array}{l}\text { Planning activities have been initiated, i.e. participated in EA public hearing in } \\
\text { Portsmouth, Ohio, briefed Ecology on path forward for burial of UU fuel. } \\
\text { However, timely DOE-HQ review and approval of billet Safety Analysis } \\
\text { Report for Packaging (SARP) is critical for Disposition. To date, } \\
\text { approximately } \$ 234 \mathrm{~K} \text { has been identified to fund Phase I activities. If the } \\
\text { remaining funds ( } ~ \$ 5 \mathrm{M}) \text { are not identified, this work scope cannot be } \\
\text { accomplished. }\end{array}$ \\
\hline Multiple & $\begin{array}{l}\text { Comprehensive } \\
\text { performance }\end{array}$ & All baseline work projected to be complete per PI requirements. \\
\hline
\end{tabular}

\section{KEY INTEGRATION ACTIVITIES}

- Complete National Facility Deactivation Initiative (NFDI) DOE-complex implementation plan.

- $\quad 324$ Building B Cell project along with Spent Nuclear Fuel (SNF) developed an alternative plan for the fuel removal activity. SNI' and DOE-RL are reviewing the options study to determine cost savings against the 200 Area Interim Storage life cycle costs.

- The DOE-HQ funded study of HLV Tank 105, located in the 324 Building is being conducted by AEA Technologies to demonstrate new technology in the deactivation of high dose radioactive tanks. The project technical plan, and implementation plan is completed while the draft of the alternatives assessment is on schedule for completion by April 2000.

- 300 Area Accelerated Closure Plan was briefed to DOE-RL by an integrated team of Fluor Hanford, Bechtel Hanford, Inc. and Pacific Northwest National Laboratory representatives participating.

- RCP Accelerated Deactivation Project personnel led a team comprised of workers from six Fluor Hanford organizations and three separate DOE contractors to complete the change out of B Plant's highly radioactive filters. This work, completed using innovative techniques and equipment was developed by this diverse work team, enhancing worker safety and productivity. This unparalleled cooperation and teamwork was recently recognized in a DOE surveillance which acknowledged that the practices and processes used during this project met expectations by RL for "World Class" contractors performing work at Hanford. 

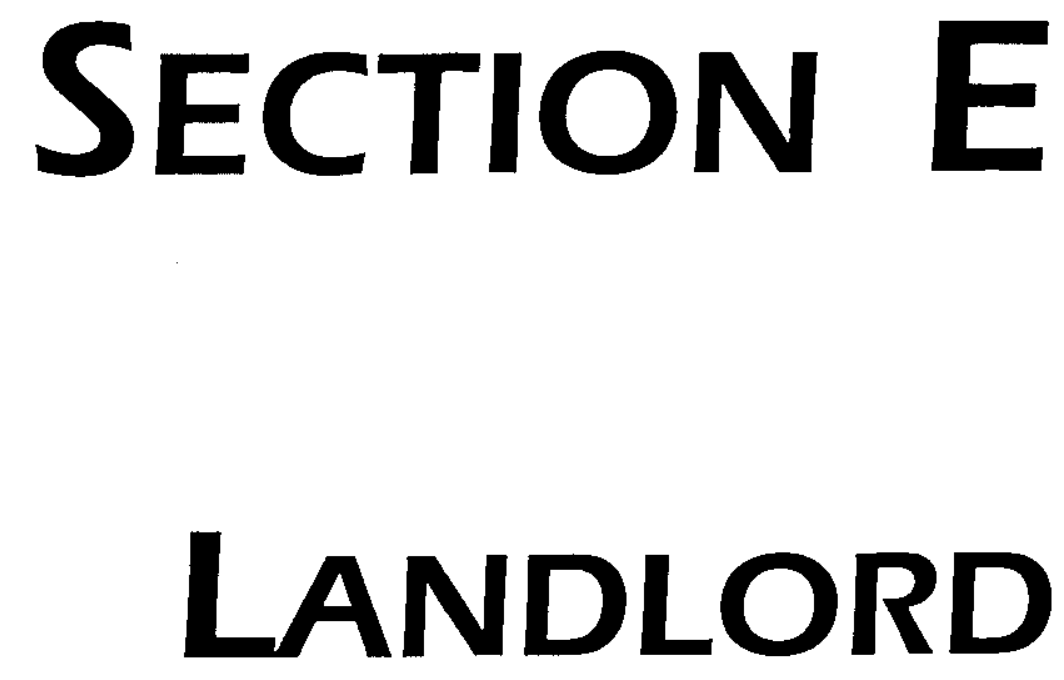

PROJECT MANAGERS

\author{
S. H. Wisness, RL \\ Phone: (509) 373-9337 \\ D. S. Kelly, FH \\ Phone: (509) 376-7334
}




\section{SUMMARY}

The Landlord mission area consists of the Landlord Project, WBS 1.5.1, Project Baseline Summary (PBS) RL-TP13.

The Landlord Project bridge change request for FY 2000 through 2002 was approved by RL and FY 2000 baseline information was loaded into HANDI enabling project performance to be demonstrated in the performance module.

Fiscal-year-to-date milestone performance (EA, DOE-HQ, Field Office, and RL) shows 0 of 0 milestones (100 percent) were completed on or ahead of schedule and 0 milestones ( 0 percent) are overdue. Details can be found in the Milestone Exception Report.

\section{ACCOMPLISHMENTS}

- Four regulated and two non-regulated cranes, which had been clcaned and released, were sold at auction generating over $\$ 700 \mathrm{~K}$ in total revenue. The money will be used to purchase a new 70-ton hydraulic mobile crane for use in the Tank Farms. 


\section{SAFETY}
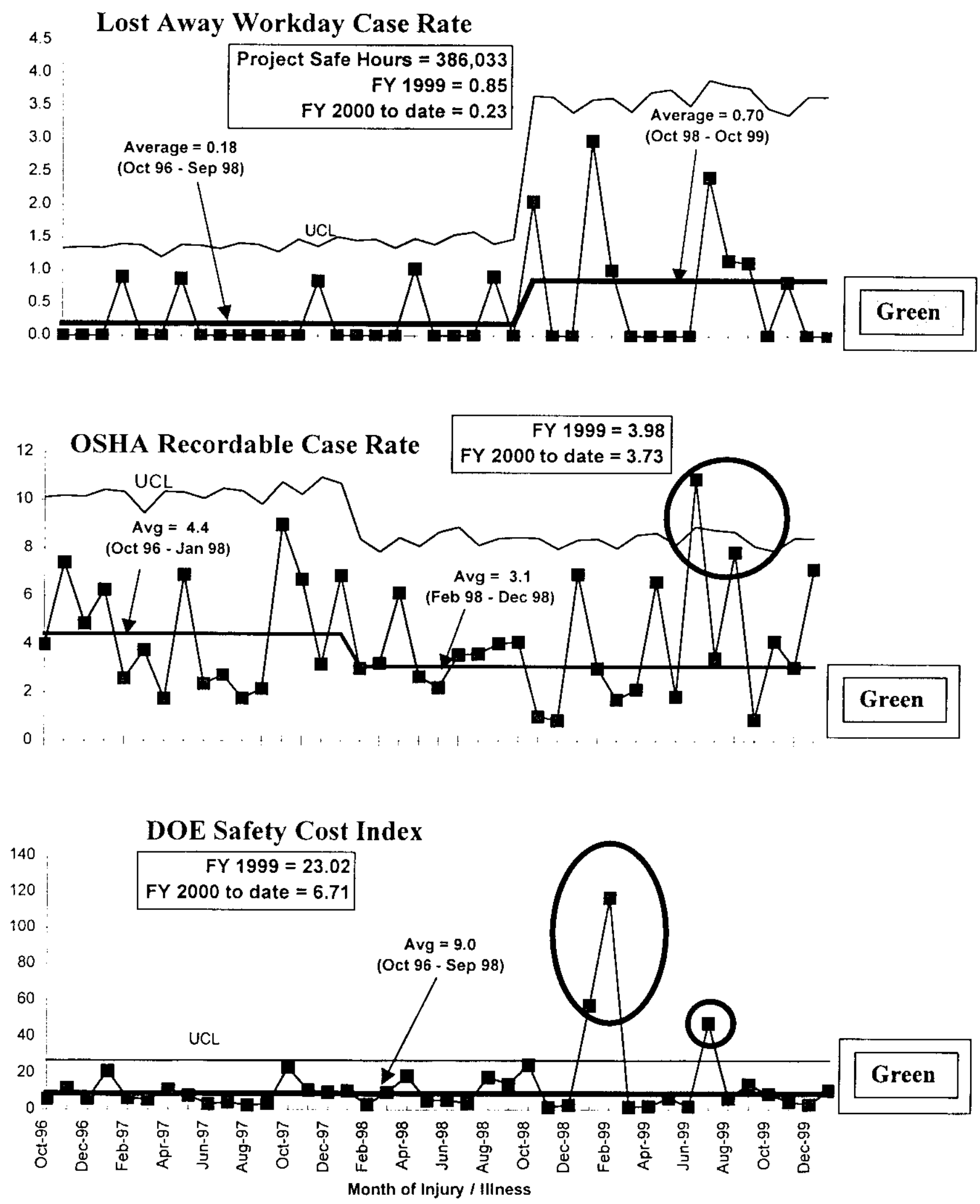


\section{ISMS STATUS}

- $\quad$ Achieved Phase I and Phase II ISMS Validation.

- Two overall recommendations received by the Validation Team:

Green

- Focus self-assessments on fieldwork: There are currently 31 Management Assessment Plans and 36 Surveillances focused on fieldwork.

- Evaluate 16 concerns expressed in the body of the report: Continue to resolve the 16 concerns identified. They are on schedule to be completed by July 1, 2000 .

\section{BREAKTHROUGHS / OPPORTUNITIES FOR IMPROVEMENT}

\section{Breakthroughs}

- Developed a Water Utility Enhancement Initiative to secure private investment to accelerate upgrades to the Hanford Site's aging water infrastructure to ensure it is fit for the Site's longterm cleanup mission. Delivered initiative to RL on February 7, 2000. Sempra Energy Solutions visited during the week of February 14 to complete initial planning efforts.

Green:

- Implementing an initiative to move nearly all Infrastructure services from indirect to direct funding. Establishing FY 2002 baseline in TP-13 "Landlord Project". Conversion will not be included in the March Project Priority List (PPL) but is currently scheduled to be included in the April PPL submittal.

\section{Opportunities for Improvement}

Green

- Prioritizing needed infrastructure upgrades through the Landlord Project by updating the baseline to reflect the movement from past philosophies of "run-to-failure" to incorporate a "fit-for-mission" approach. Continue to pursue the funding required to complete needed upgrades.

Yellow

- A Return on Investment proposal to clean and free release 10 pieces of heavy equipment currently managed by Fleet Maintenance was developed. The money generated from the excess and offsite sale of this equipment will be used to clean and free release additional equipment, therefore developing a self-sustaining process for the reduction and reuse of legacy regulated equipment. This equipment was destined for eventual burial as low-level waste, at an estimated cost of over $\$ 900,000$. 


\section{UPCOMING ACTIVITIES}

- Update the 1100 Area Vacate Plan which will focus primarily on identifying alternative locations to perform current and proposed warehousing activities and revising the costs associated with this potential relocation.

- As a result of accomplishing Phase I and II ISMS Verification, DynCorp is now rededicating itself to achieving Voluntary Protection Program (VPP) Star Status.

- Preparatory work continues on flat car and well car characterization activities and on agreements for the transfer of flat cars to the Tri-Cities Asset Reinvestment Company through the Equipment Dispositioning Project (EDP).

\section{Cost Performance $(\$ M)$ :}

\begin{tabular}{|l|c|c|c|}
\hline & BCWP & ACWP & VARIANCE \\
\hline Landlord & $\$ 2.9$ & $\$ 1.4$ & $+\$ 1.6$ \\
\hline
\end{tabular}

The $\$ 1.6$ million ( $53.5 \%$ percent) favorable cost variance is mainly attributed to the auction of six cranes for which a credit was received. Further information at the PBS level can be found in the following Cost Variance Analysis details.

\section{Schedule Performance ( $\$ M)$ :}

\begin{tabular}{|l|c|c|c|}
\hline & BCWP & BCWS & VARIANCE \\
\hline Landlord & $\$ 2.9$ & $\$ 3.9$ & $-\$ 1.0$ \\
\hline
\end{tabular}

The $\$ 1.0$ million ( 25.7 percent) unfavorable schedule variance is attributed to funding reductions that impacted work scope related to Project L-314, Law Enforcement and Security Training Center. Renovations for water and restroom facilities will be deferred. Further information at the PBS level can be found in the following Schedule Variance Analysis details. 


\section{WBS 1.5.1 \\ FY 2000 Cost/Schedule Performance - All Fund TyPes Cumulative to Date Status - $(\$ 000)$}

\begin{tabular}{|c|c|c|c|c|c|c|c|c|c|c|c|c|c|}
\hline \multirow{2}{*}{\multicolumn{2}{|c|}{ By PBS }} & \multicolumn{7}{|c|}{ FYTD } & \multirow[b]{2}{*}{ BAC } & \multirow[b]{2}{*}{ EAC } & & & \multirow[t]{2}{*}{ Rating } \\
\hline & & BCWs & BCWP & ACWP & sv & $\%$ & $\mathrm{cV}$ & $\%$ & & & & $\begin{array}{l}\text { rojected } \\
\text { funding }\end{array}$ & \\
\hline \multirow[t]{3}{*}{ WBS 1.5 .1} & Landlord & $\$ 3,934$ & $\$ 2,922$ & $\$ 1,358$ & $\$(1,012)$ & $-26 \%$ & $\$ 1,564.0$ & $54 \%$ & $\$ 15,793$ & S 12,771 & $\$$ & 12.771 & Yellow \\
\hline & Total & $\$ 3,934$ & $\$ 2,922$ & \$ 1,358 & $\$(1,012)$ & $-26 \%$ & $\$ 1.564 .0$ & $54 \%$ & $\$ 15,793$ & $\$ 12,771$ & $\$$ & 12,771 & \\
\hline & & & & & & & & & & & & \multicolumn{2}{|c|}{ Yellow } \\
\hline
\end{tabular}

\section{Cost/Schedule Performance Indices (JANUARY 2000 AND FYTD)}

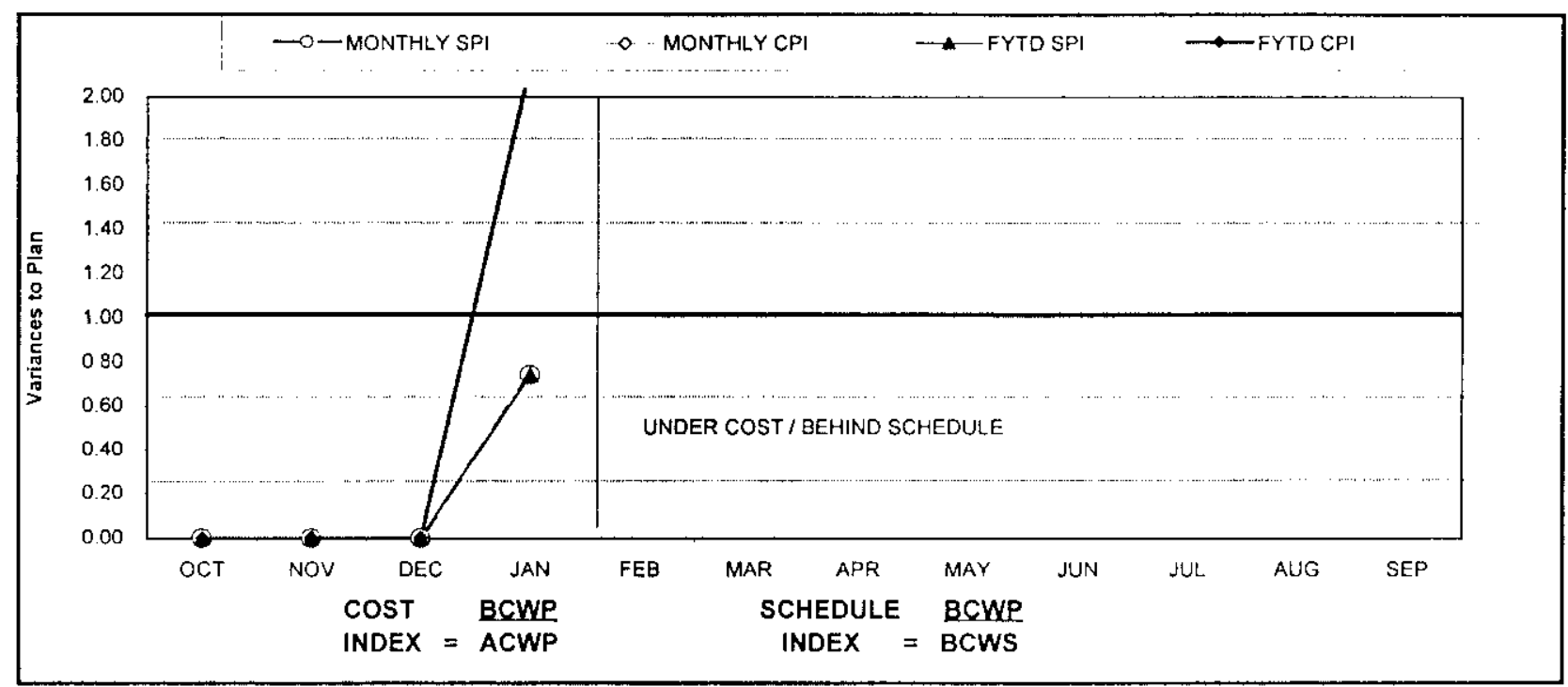

\begin{tabular}{|c|c|c|c|c|c|c|c|c|c|c|c|c|}
\hline FY 2000 & OCT & NOV & DEC & JAN & FEB & MAR & APR & MAY & JUN & JULL & AUG & SEP \\
\hline MONTHLY SPI & 0.00 & 0.00 & 0.00 & 0.74 & & & & & & & & \\
\hline MONTHLY CPI & 0.00 & 0.00 & 0.00 & -18.85 & & & & & & & & \\
\hline FYTD SPI & 0.00 & 0.00 & 0.00 & 0.74 & & & & & & & & \\
\hline FYTD CPI & 0.00 & 0.00 & 0.00 & 2.15 & & & & & & & & \\
\hline MONTHLY BCWS & $\$ 0$ & $\$ 0$ & $\$ 0$ & $\$ 3,934$ & & & & & & & & \\
\hline MONTHLY BCWP & $\$ 0$ & $\$ 0$ & $\$ 0$ & $\$ 2,922$ & & & & & & & & \\
\hline MONTHLY ACWP & $\$ 197$ & $\$ 549$ & $\$ 767$ & (\$155) & & & & & & & & \\
\hline FYTD BCWS & $\$ 0$ & $\$ 0$ & $\$ 0$ & $\$ 3,934$ & & & & & & & & \\
\hline FYTD BCWP & $\$ 01$ & $\$ 0$ & $\$ 0$ & $\$ 2,922$ & & & & & & & & \\
\hline FYTD ACWP & $\$ 197$ & $\$ 746$ & $\$ 1.513$ & $\$ 1,358$ & & & & & & & & \\
\hline
\end{tabular}




\section{ISSUES}

\section{Technical Issues}

None.

\section{DOE/Regulator/External Issues}

Nothing to report.

\section{Cost Variance Analysis: $(+\$ 1.6 \mathrm{M})$}

WBS/PBS

1.5.1/TP-13 attributed to the auction of six cranes for which a credit was received. Procurement of one new crane is scheduled to be received next year (long lead procurement). In addition, the Municipal Planning Process and the Infrastructure Plan are underruning because they are behind schedule. Also, line item funding from completed projects still in the baseline and reflecting a cost variance.

Impact: No impact to overall project and/or final cost.

Corrective Action: A requisition has been entered into Passport to procure the new crane, which replaces the six that were sold.

\section{Schedule Variance Analysis: (- \$1.0M)}

\section{WBS/PBS}

\subsection{1/ WM03}

Description /Cause: The \$1.0 million (25.7 percent) unfavorable to funding reductions that impacted work scope related to Project L-314, Law Enforcement and Security Training Center. Renovations for water and restroom facilities will be deferred. In addition, two ambulances are behind the scheduled delivery date and will be received in April. The Municipal Planning Process and the Infrastructure Plan are behind schedule due to completion of other work scope. Furthermore, we are working with RL to begin implementation of the Municipal Planning process. Several other projects had a late start due to the task order process.

Impact: Funding reductions require that scope be deferred for Project L-314 through a Baseline Change Request (BCR). Ambulances will be received in April. Other project delays are projected to be overcome with no overall impact to the project.

Corrective Action: A BCR will be implemented to address deferred workscope due to funding reductions and impacts for the rate changes. 


\title{
Baseline Change Requests Currently in Process $(\$ 000)$
}

\begin{tabular}{|c|c|c|c|c|c|c|c|c|c|}
\hline $\begin{array}{l}\text { PROJECT } \\
\text { CHANGE } \\
\text { NUMBER }\end{array}$ & $\begin{array}{c}\text { DATE } \\
\text { ORIGIN. }\end{array}$ & BCR TITLE & $\begin{array}{l}\text { FY00 COST } \\
\text { IMPACT \$000 }\end{array}$ & $\mathrm{SCH}$ & TECH & $\begin{array}{c}\text { DATE TO } \\
\text { CCB }\end{array}$ & $\begin{array}{c}\text { CCB } \\
\text { APR'VD }\end{array}$ & $\begin{array}{c}\text { RL } \\
\text { APR'VD }\end{array}$ & $\begin{array}{l}\text { CURRENT } \\
\text { STATUS }\end{array}$ \\
\hline $\begin{array}{l}\text { LPM-00-001 } \\
\text { LPM-00-003 }\end{array}$ & $\begin{array}{l}11 / 3 / 99 \\
12 / 8 / 99\end{array}$ & $\begin{array}{l}\text { MYWP Baseline Module } \\
\text { (Bridge BCR FY00, 01, 02) } \\
\text { Document FY99 Carryover Funds }\end{array}$ & $\begin{array}{l}\$ 4,642 \\
\$ 1,793\end{array}$ & $\mathrm{x}$ & $\begin{array}{l}X \\
X\end{array}$ & $\begin{array}{c}1 / 11 / 00 \\
12 / 13 / 00\end{array}$ & $\begin{array}{l}1 / 14 / 00 \\
1 / 3 / 00\end{array}$ & $\begin{array}{c}1 / 27 / 00 \\
1 / 3 / 00\end{array}$ & $\begin{array}{l}\text { Approved by RL } \\
\text { Approved by RI. }\end{array}$ \\
\hline \multicolumn{10}{|c|}{ ADVANCE WORK AUTHORIZATIONS } \\
\hline
\end{tabular}

\section{LANDLORD - WBS 1.5.1 \\ MILESTONE ACHIEVEMENT}

\begin{tabular}{|c|c|c|c|c|c|c|c|c|}
\hline \multirow[b]{2}{*}{ MILESTONE TYPE } & \multicolumn{2}{|c|}{ FISCAL YEAR-TO-DATE } & \multirow[b]{2}{*}{$\begin{array}{c}\text { Completed } \\
\text { Late }\end{array}$} & \multirow[b]{2}{*}{ Overdue } & \multicolumn{3}{|c|}{ REMAINING SCHEDULED } & \multirow[b]{2}{*}{$\begin{array}{c}\text { TOTAL } \\
\text { FY } 2000\end{array}$} \\
\hline & $\begin{array}{l}\text { Completed } \\
\text { Early }\end{array}$ & $\begin{array}{c}\text { Completed } \\
\text { On Schedule }\end{array}$ & & & $\begin{array}{c}\text { Forecast } \\
\text { Early }\end{array}$ & $\begin{array}{l}\text { Forecast } \\
\text { On } \\
\text { Schedule }\end{array}$ & $\begin{array}{c}\text { Forecast } \\
\text { Late }\end{array}$ & \\
\hline Enforceable Agreement & 0 & 0 & 0 & 0 & 0 & 0 & 0 & 0 \\
\hline DOE-HQ & 0 & 0 & 0 & 0 & 0 & 0 & 0 & 0 \\
\hline $\mathrm{RL}$ & 요 & 0 & 0 & 0 & 0 & 12 & 0 & 12 \\
\hline Total Project & 0 & 0 & 0 & 0 & 0 & 12 & 0 & 12 \\
\hline
\end{tabular}

\begin{tabular}{|l|l|}
\hline & Tri-Party Agreement / EA Milestones \\
\hline Nothing to report. & \\
\hline & DNFSB Commitments \\
\hline Nothing to report & \\
\hline
\end{tabular}

\section{MiLestone EXCEPTION REPORT}

\begin{tabular}{|c|c|}
\hline Number/NBS Level & Milestone Title \\
\hline
\end{tabular}

\author{
OVERDUE - 0
}

FORECAST LATE - 0

FY 1999 OVERDUE - 0 


\section{Performance Objectives}

\begin{tabular}{|c|c|c|}
\hline Outcome & Performance Indicator & Status \\
\hline \multirow{7}{*}{$\begin{array}{l}\text { Restore the River } \\
\text { Corridor for Multiple } \\
\text { Uses } \\
\& \\
\text { Transition the Central } \\
\text { Plateau }\end{array}$} & $\begin{array}{l}\text { Replace } 1,500 \text { Feet of } 2 \text {-inch } \\
\text { Sanitary Water Line from } \\
272 \mathrm{AW} \text { Building Along Canton } \\
\text { Ave. in the } 200 \text { East Area }\end{array}$ & \\
\hline & $\begin{array}{l}\text { Provide Vegetation and Animal } \\
\text { Control to Reduce/Minimize the } \\
\text { Spread of Contamination }\end{array}$ & $\begin{array}{l}\text { Treated } 1,890 \text { acres fiscal year to date. Activities continue } \\
\text { as scheduled. }\end{array}$ \\
\hline & $\begin{array}{l}\text { Disposition } 38 \text { Abandoned } \\
\text { Legacy Non-Radioactive Waste } \\
\text { Sites }\end{array}$ & \\
\hline & $\begin{array}{l}\text { Complete Roof Replacement on } \\
325 \text { Building South }\end{array}$ & \\
\hline & \begin{tabular}{|l|} 
Complete Installation of \\
$100 \mathrm{~K} / \mathrm{D}$ Emergency Notification \\
Sirens which will Complete the \\
Total Integration of All Outside \\
Sirens
\end{tabular} & \\
\hline & $\begin{array}{l}\text { Complete Emergency Services } \\
\text { Renovation of the } 200 \text { Area Fire } \\
\text { Station }\end{array}$ & $\begin{array}{l}\text { Demolition of } 609 \mathrm{C} \text { was completed on February } 23 \text {, two } \\
\text { months ahead of schedule. Construction completion of the } \\
\text { new Administration/Dormitory wing is approximately one } \\
\text { month ahead of the scheduled completion date of April } 6 \text {, } \\
2001 \text {. }\end{array}$ \\
\hline & $\begin{array}{l}\text { Shutdown Approx. } 20 \text { Vacant } \\
\text { Office Facilities - Isolate } 25 \\
\text { Vacant Facilities }\end{array}$ & $\begin{array}{l}5 \text { facilities have been shutdown for the fiscal year. } 9 \\
\text { facilities have been isolated. Project is on schedule. }\end{array}$ \\
\hline $\begin{array}{l}\text { Put Assets to Work for } \\
\text { the Future }\end{array}$ & $\begin{array}{l}\text { Disposition One Well Car and } \\
\text { One Flat Car - Surveillance and } \\
\text { Maintenance of Legacy Rail } \\
\text { Cars at } 212 \mathrm{R} \text { Awaiting } \\
\text { Disposition }\end{array}$ & $\begin{array}{l}\text { Detailed surveys of the flat cars continue as weather } \\
\text { permits. Preliminary investigation into an option to } \\
\text { prepare the Burlington Northern Santa Fe flat cars for free } \\
\text { release at Hanford was initiated. The National } \\
\text { Environmental Policy Act Categorical Exclusion review } \\
\text { package was received by DOE-RL and has started internal } \\
\text { reviews. }\end{array}$ \\
\hline
\end{tabular}

\section{KEY INTEGRATION ACTIVITIES}

- Support Hanford Comprehensive Land Use Plan (CLUP). Record of Decision was issued in November 1999 which mandates that within the next 24 months, Real Estate will be managed like a municipality.

- Continue to support development of the 300 Area Accelerated Closure planning project as required. Provided cost estimates for the development of a Utilities Plan and a Relocation Plan in support of the accelerated closure. 

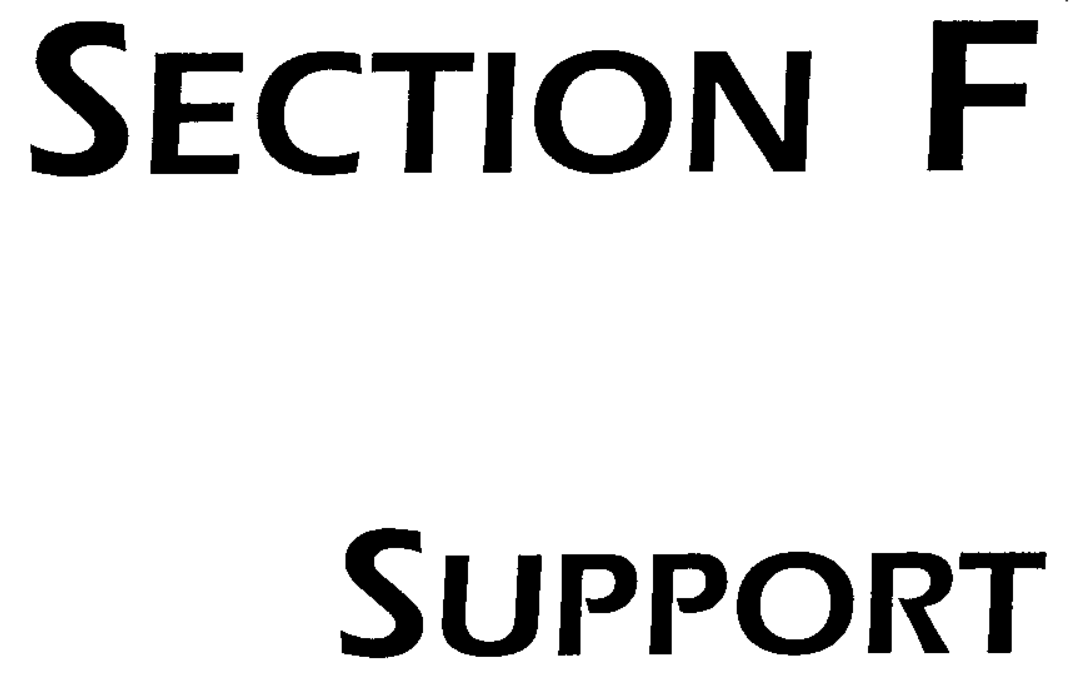

PROJECT MANAGERS

SP\&I W. W. Ballard, RL G. J. McCleary, FH SSE W. W. Ballard, RL M. L. Grygiel, FH

ECP S. H. Wisness, RL J. W. Hales, FH PSRP S. H. Wisness, RL R. L. Dirkes, PNNL
(509) 376-6657 (509) 372-8385 (509) 376-6657 (509) 372-2983 (509) 373-9337 (509) 376-4069 (509) 373-9337 (509) 376-8177 


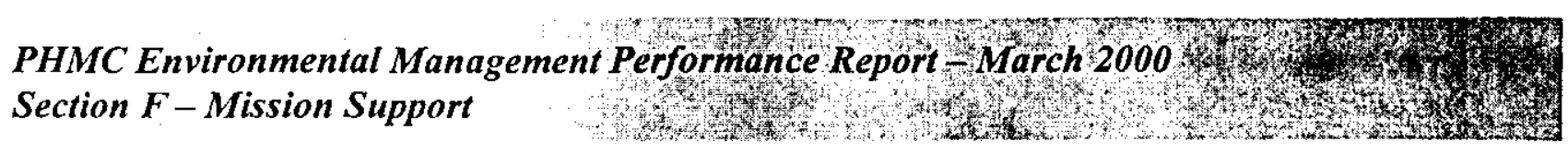

\section{SUMMARY}

Mission Support, Project Baseline Summary (PBS) OT01, consists of four sub-projects:

- $\quad$ Planning and Integration (Work Breakdown Structure (WBS 1.8.2.1)

- $\quad$ Systems Engineering (WBS 1.8.2.2)

- $\quad$ Environmental Compliance (WBS 1.8.2.3)

The Environmental Compliance Program is composed of two elements. These two elements were stand-alone programs known as the Hanford Environmental Management Program (HEMP) and the Effluent and Environmental Monitoring Program (EEM) prior to FY99. Although there is a single program, these elements retain their identity on the Integrated Priority List as two separate Units of Analysis.

- $\quad$ Public Safety and Resource Protection (WBS 1.8.2.4)

NOTE: Unless otherwise noted, the Safety, Conduct of Operations, and Cost/Schedule data contained herein is as of January 31,2000. All other information is as of March 1, 2000.

Fiscal-year-to-date milestone performance (EA, DOE-HQ, FO, and RL) shows that 7 of 8 milestones ( 88 percent) were completed on or ahead of schedule, 1 milestone (12 percent) was completed late. The Milestone Achievement details, found following cost and schedule variance analysis, provide further information on all milestone types. Additional details on the forecast late milestone can be found in the milestone exception report.

\section{Site, Planning and Integration (SP\&I)}

FY 2001 Budget Cycle - The Limited Project Baseline Summary (PBS) update was delivered to DOE-HQ on January 12, 2000. This update supported the completion of the FY 2001 President's Budget request to Congress. Updates to PBS's for the FY 2002 Budget Formulation Cycle are being prepared and updated based on the latest Mission Planning Guidance (MPG) requirements and guidance from DOE-HQ.

Integrated Priority List (IPL) Module Enhancements - Based upon new functionality requirements as identified in the MPG, as well as changes brought about by the Office of River Protection split, Site Planning and Integration (SP\&I) completed an update of the prioritization system to add new data elements, new sort functionality, and new report formats in support of the work prioritization process. Modifications also included the ability to generate individual IPLs for each contractor in support of RL's new role as integrator. These actions were directed pending submission and approval of a baseline change request to incorporate the scope and additional funding requirements in the SP\&I Multi-Year Work Plan (MYWP).

Code of Account Modifications - With the implementation of the Hanford Data Integrator 2000 systems, FH utilized a Code of Account (COA) capability to simplify the work breakdown structure for managing FH's project work. As part of FY 2000 startup, an evaluation was made to assess the utilization of the COA's that were put in place. The evaluation resulted in a number 
of changes in COA's which are used to track cost of activities common to all FH projects. Changes in the COA's included additions in areas where activities needed more detailed definition, and elimination in other areas where they were determined to be redundant or not useful. During January, SP\&I and Finance worked with projects to complete updates to coding on existing contracts and documents to the updated COA assignments.

FY2002 Budget Formulation Cycle - In mid-to-late January, SP\&I staff reviewed and commented on improvements and concerns included in the Draft Mission Planning Guidance (MPG). The MPG was issued on January 24, 2000. The MPG specified FH deliverables for the FY 2002 Budget Formulation process ranging from January through June 2002. Separate MPG's were issued to $\mathrm{BHI}, \mathrm{PNNL}$ and ORP making them responsible for their own budget submissions during this Budget Cycle. SP\&I will not act as the integrator for the RL IPL. This is a change from SP\&I's role in past years.

In accordance with the MPG, the Draft Project Priority Lists (PPLs) were delivered on January 27, 2000. FH held reviews of the FY2001 PPLs with each of the Projects. The reviews consisted of checking for data quality and completeness.

The Integrated Priority List (IPL) Module was available on January 27, 2000 to produce the projects' submission of the Project Priority Lists (PPLs), and to support the development of the FH Draft FY 2002 IPL. Significant effort was made to train project staff, provide guidance on the new system, and ensure reporting requirements were met. Changes continue to be made on a quick turnaround basis.

Paths to Closure Documents Delayed - DOE-HQ delayed issuance of the National and Site Paths to Closure documents to allow for further review. As of this writing, the authorization to print has not yet been provided.

Integrated, Planning, and Budget System (IPABS) Training - Six representatives from DOE-IIQ delivered IPABS user training at the Hanford Training Center and HAMMER on January 25-26, 2000. Module specific and general overview training was provided to site contractor personnel. The training included a system overview as well as specific orientation on the planning, budget, project execution, and reporting modules. The training also included instruction on the electronic batch loading process and an on-line demonstration.

Modeling Tool Development - SP\&I was requested to develop a summary schedule product for assessing various "what-if" scenarios and associated impacts to work scope priorities. Several sessions were conducted to quantify product requirements, cost, and schedule. Effort to develop this product utilizing project-level resource schedules was initiated in late January with a projected completion date of early May. This activity is being performed in place of existing schedule products pending submission and approval of a baseline change requesting additional funding to support the effort.

Inspector General Activities - FH supported involvement with the Office of Inspector General (OIG) regarding the FY 1999 Financial Statements for the Environmental liabilities 
requirements. In support of the OIG audit, $\mathrm{FH}$ provided narratives addressing subsequent events that occurred since September 30,1999, that have a significant impact (materiality threshold of $\$ 5$ million or greater) on the DOE RL/ORP financial statements. [Ed. note: All necessary support was provided and on February 14, 2000 RL indicated that the action was completed.]

Call for Independent Centers - On January 26, 2000, DOE-HQ requested information from RL-Budgets on Independent Centers. This was a follow-up to an early request to meet requirements specified in the Energy and Water Defense Appropriation (EWDA) Conference Report (106-335) that directed the Department of Energy to provide the House and Senate Committees on Appropriations a list of all such centers at each laboratory or facility, their annual cost, number of employees, and source of funding. FH was requested to support in evaluating which activities might meet the definitions of an Independent Center. The only one under FH's responsibility that may meet the criteria is HAMMER; a summary write-up of HAMMER was provided.

Environmental Compliance Program (ECP) - Three ECP Milestones were due in January. Two of these were completed early and one was completed on time.

\section{Spill/Release Reporting:}

For the month of January, ECP coordinated the reporting activities for five (5) non-reportable releases to the environment of hazardous substances and/or petroleum products, one (1) reportable event with a release to the environment and six (6) reportable code non-compliance events reported to the off site regulatory agency(s) without a release to the environment.

\section{Inspections/Assessments}

Coordinated 5 regulator inspections and followed up on information requests pertaining to these and past inspections:

- January 6, Washington State Department of Health (WDOH) performed a Minor Stack Inspection at the 222-S Laboratory Complex.

- January 13, WDOH performed an EPA Level II inspection of the EP-324-0-S Stack located at the 324 facility.

- January 26, WDOH performed an initial inspection including a kickoff meeting for investigating Emergency Preparedness.

- January 27, Ecology performed follow-up inspection at T-Plant and 222-S on the M-32 milestone.

- January 31, WDOH performed a Minor Stack Inspection on the stacks located at the PFP complex.

Field and regulatory file assessments of Central Waste Complex (CWC), Low-level Burial Ground (LLBG), 616 Non-Radioactive Dangerous Waste Storage Facility (NRDWSF), and T- Plant were completed in January. 


\section{RCRA Permit Revision and Implementation:}

Prepared draft Permit for Corrective Action portion, which reflected the comments, that DOE sent to Ecology on December 20, 1999. The draft Permit was prepared at the request of Department of Energy-Office Support Systems (DOE-OSS) to support negotiations between DOE and the regulators on the Corrective Action portion of the Permit.

The comment package submitted for Modification E of the Permit was distributed for review. The package excluded the draft Permit Conditions that were accepted in the comment package. The TSD units were requested to indicate which comments would be under consideration for appeal of the Permit. This effort was initiated to support an appeal decision once Revision 6 of the Permit is issued by Ecology.

Prepared draft Attachment 27, Permit Modification Schedule to reflect the comments provided to Ecology in Modification E. The draft of Attachment 27 will be provided to Ecology at the February Permit Steering Committee meeting.

Supported DOE-OSS with the January 10, 2000, transmittal of the Quarterly Class 1 Permit modification for quarter ending December 31, 1999. Units included in the modification package were the Liquid Effluent Retention Facility/East Tank Farm (LERF/ETF), 242-A Evaporator, and the 305-B Storage Facility.

\section{Air Support}

Provided assistance to PFP by locating previous permitting/compliance documentation regarding use of muffle furnaces at the facility.

Supported the B Plant by addressing BHI-based concerns regarding a possible need for a continuous air monitor (CAM) on the new B Plant main stack. Based upon initial data supplied by the facility, a position was offered showing that the potential emissions at the stack did not trigger the DOE-RL requirements for CAM operation. This action supports the transfer of the facility to BHI on schedule.

Supported 222-S by gathering background documentation and successfully demonstrating that recent upgrades of the 222-S main stack vent system were adequately approved by the WDOH. This support allowed the facility to successfully respond to concerns from the WDOH and avoid further compliance action.

Supported the RCP by providing a thorough assessment of calibration requirements associated with differential pressure (DP) gauges and rotameters.

\section{Project Support/Coordination}

Supported ES\&H involvement in FH process for confirming readiness for RL to proceed with certifying that they are prepared to support the next phase of the ORP/BNFL vitrification plant. 


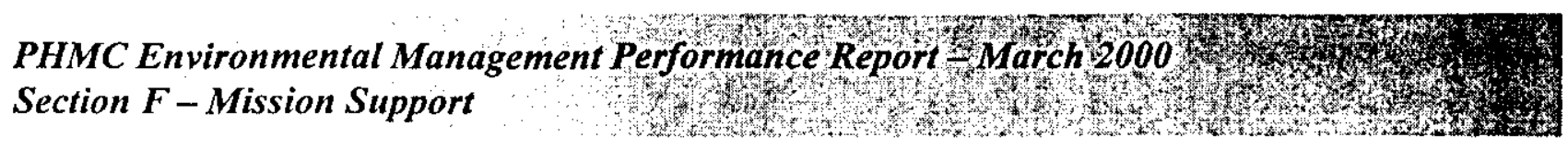

Performed an assessment of Environment and Regulation readiness to support SNF operations. The assessment concluded that environment and regulation resources are adequate and properly trained to support SNF operations.

Continued recovery program actions for the Waste Sampling and Characterization Facility (WSCF) Test Method deviation issue and associated sitewide impacts, including:

- $\quad$ issued 3 status updates for the Resource Conservation and Recovery Act (RCRA) Focus Action Plan

- drafted Land Disposal Restrictions (LDR) action plan for submittal to Ecology

- $\quad$ supported development of a draft 200.8 Deviation/RCRA Position Paper

\section{Management and Administrative Support}

Initiated Integrated Environmental Safety and Health Management Systems (ISMS) readiness activities including establishment and indoctrination of a Environmental Services (ES) Readiness Assistance Team and preparation of desk instructions to cover ES activities that were not covered by procedures.

Public Safety and Resource Protection (PSRP) - The PSRP Program Projects were all conducted in accordance with the scope, milestones, and budget defined in the FY 2000 PSRP Program (PBS \#RL-OT01) Multi-Year Work Plan during January.

\section{ACCOMPLISHMENTS}

- The deliverable, Support RL in the update of the MPG was completed on January 20, 2000.

- The deliverable, Support MPG development with Strategic Planning Group was completed on January 20, 2000.

- The milestone, ECP-00-303, RCRA Permit Class 1 Modification Quarter 2 due on 01/03/00, was completed 12/16/99, 18 days ahead of schedule.

- The milestone, ECP-00-402, Provide RL with Air/Water Permitting Schedule, due on 01/04/00, was completed on schedule.

- $\quad$ The milestone, ECP-00-902, Issue Quarterly NESHAP Status Report to RL for EPA, due on $01 / 28 / 00$, was submitted on $01 / 13 / 00,15$ days ahead of schedule.

- $\quad$ PNNL Key Milestone RLOT013002, "Issue CY 2000 Environmental Surveillance Master Sampling Schedule," was completed, January 27, one month ahead of schedule.

- The article "Mule Deer Antlers as Biomonitors of Strontium-90 on the Hanford Site" was published in the Journal of Environmental Radioactivity (Vol. 47:29-44). Authors were B.L. Tiller and T.M. Poston. This was an account of work performed under the Surface Environmental Surveillance Project and the Ecosystem Monitoring Project.

- The Draft Hanford Site Historic District Book (PNNL Key Milestone RLOT015003) was completed and submitted for public review during the month.

A number of significant activities occurred during January to support the interagency

(Washington Department of Fish and Wildlife [WDFW], US Fish and Wildlife Service, and 


\section{PHMC Environmental Management Performance Report -4 arch 2000 \\ Section F-Mission Support}

DOE) effort to reduce the Rattlesnake Hills elk herd. They included:

- Comments to the WDFW Elk Management Plan were provided to the WDFW on January 28.

- Initial radiological data on radioactive materials concentrations is elk tissue were summarized and presented at a series of three public meetings held in eastern Washington (Kennewick, January 12; Clarkston, January 13; and Newport, January 14).

- Analysis for elk tissue samples continued from three samples provided by the $\mathrm{Ne}_{2} \mathrm{Perce}$ Tribe and for fecal samples from Hanford.

- Work continued on flight safety planning for helicopter use during the elk capture scheduled for March.

- The winter post-harvest census for elk was completed during January. Approximately 740 elk were observed within the Rattlesnake Hills herd and all of the animals were concentrated in several large herds on the Fitzner/Eberhardt Arid Lands Ecology Reserve. Also, the historic data on elk harvests maintained by the Project were summarized. Both the current census data and the harvest summary were provided to the WDFW to support management planning for the Rattlesnake Hills elk herd, in particular the planning for the herd reduction that is in progress.

Mission Support currently has no status to report in the areas of Safety, Conduct of Operations, ISMS Status, Breakthroughs, Opportunities for Improvement, and Upcoming Activities.

\section{Cost Performance $(+1.2 \mathrm{M})$ :}

\begin{tabular}{|l|c|c|c|}
\hline & BCWP & ACWP & VARIANCE \\
\hline Mission Support 1.8.2 & $\$ 7.4$ & $\$ 6.2$ & $\$ 1.2$ \\
\hline
\end{tabular}

The $\$ 1.2$ million (eleven percent) favorable cost variance is due to Site Systems Engineering straight lining the vendor support for Site Level Analysis and Modeling. The vendor has performed the majority of their workscope during the first 4 months of the fiscal year. It is also caused by accrual reversals for which no offsetting payments were entered into the financial tracking system. The FY 1999 accruals were inadvertently reversed prior to actual charges hitting. A smaller portion of the variance is attributed to less than anticipated activity in some level-of-effort activities. The remainder of the favorable variance is primarily due to Chemical Management contract costs to date being less than anticipated in the Environmental Compliance Program.

\section{Schedule Performance $(\$-0.4 M):$}

\begin{tabular}{|l|c|c|c|}
\hline & BCWP & BCWS & VARIANCE \\
\hline Mission Support 1.8.2 & $\$ 7.4$ & $\$ 7.0$ & $-\$ 0.4$ \\
\hline
\end{tabular}

The $\$ 0.4$ million (five percent) unfavorable schedule variance is within acceptable reporting thresholds. 
PHMC Environmental Management Performance Report $=$ March 2000

Section F-Mission Support

Fy 2000 COSt/SChedule Performance - All Fund Types MISSION SUPPORT

WBS 1.8

\section{Cumulative to Date Status - (\$000) FYTD}

\begin{tabular}{|c|c|c|c|c|c|c|c|c|c|c|c|c|c|c|}
\hline \multicolumn{2}{|r|}{ By PBS } & \multicolumn{2}{|c|}{ BCWS } & \multicolumn{2}{|c|}{ BCWP } & \multicolumn{2}{|c|}{ ACWP } & sv & $\%$ & $\mathrm{cv}$ & $\%$ & Auth Bsin & PTS BCWS & \multirow[t]{2}{*}{ Rating } \\
\hline 1.8 .1 & RL Directed & & & & & & & & & & & & & \\
\hline OT04 & Supported & $\$$ & 5,706 & $\$$ & 5,064 & $\$$ & 5.033 & $\$(642)$ & $-11 \%$ & $\$ 31$ & $1 \%$ & $\$ 17,962$ & - & \\
\hline $\begin{array}{l}1.8 .2 \\
\text { OTO1 }\end{array}$ & $\begin{array}{l}\text { Mission } \\
\text { Support Other } \\
\text { MYPs }\end{array}$ & $\$$ & 7,384 & $\$$ & 7,040 & $\$$ & 6.287 & $\$(344)$ & $.5 \%$ & 8753 & $11 \%$ & \& 25.589 & \& 28053 & Yellow \\
\hline & otal & $\$$ & 3,090 & $\$$ & 2.104 & $\$$ & 11,320 & $\$(986)$ & $-8 \%$ & $\$ 784$ & $6 \%$ & $\$ 43,551$ & $\$ 28,053$ & \\
\hline
\end{tabular}

\section{Cost/Schedule Performance Indices (JANUARY 2000 AND FYTD)}

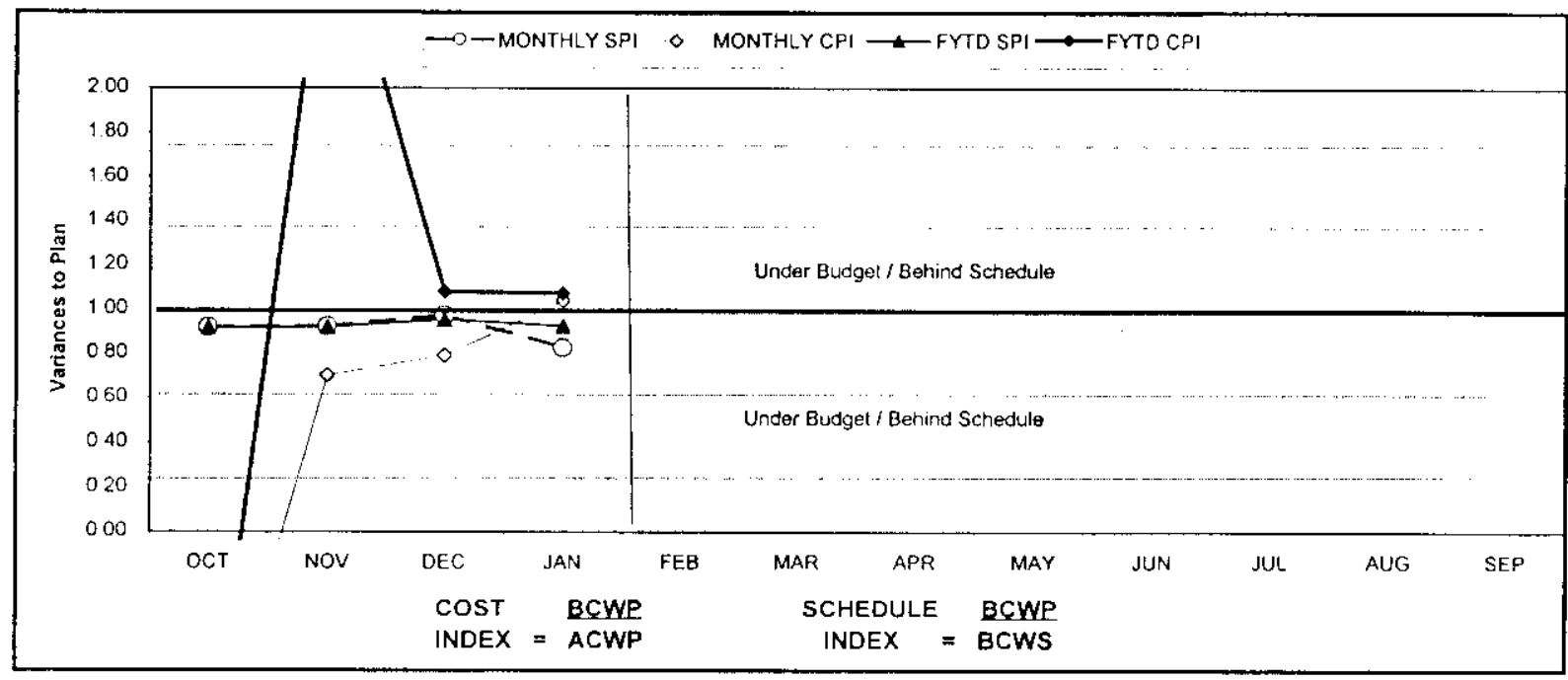

\begin{tabular}{|c|c|c|c|c|c|c|c|c|c|c|c|c|}
\hline FY 2000 & $\mathrm{OCT}$ & NOV & $\mathrm{DEC}$ & JAN & FEB & MAR & APR & MAY & JUN & JUL & $\overline{A U G}$ & SEP \\
\hline MONTHLY SPI & 0.92 & 092 & 0.97 & 0.83 & & & & & & & & \\
\hline MONTHLY CPI & -1.15 & 070 & 0.79 & 1.04 & & & & & & & & \\
\hline FYTD SPI & 092 & 092 & 095 & 0.92 & & & & & & & & \\
\hline FYTDCPI & -1.15 & 290 & 108 & 1.07 & & & & & & & & \\
\hline MONTHLY BCWS & $\$ 1.84 \overline{8}$ & $\$ 2,071$ & $\$ 6.381$ & $\$ 2,790$ & & & & & & & & \\
\hline MONTHLY BCWP & $\$ 1,694$ & $\$ 1,907$ & $\$ 6.199$ & $\$ 2,304$ & & & & & & & & \\
\hline MONTHLY ACWP & $(\$ 1,478)$ & $\$ 2.720$ & $\$ 7,858$ & $\$ 2.220$ & & & & & & & & \\
\hline FYTD BCWS & $\$ 1,848$ & $\$ 3.919$ & $\$ 10,300$ & $\$ 13,090$ & & & & & & & & \\
\hline FYTD 8CWP & $\$ 1,694$ & $\$ 3.601$ & $\$ 9.800$ & $\$ 12,104$ & & & & & & & & \\
\hline FYTO ACWP & $(\$ 1,478)$ & $\$ 1242$ & $\$ 9.100$ & $\$ 11,320$ & & & & & & & & \\
\hline
\end{tabular}

\section{ISSUES}

Nothing to report. 


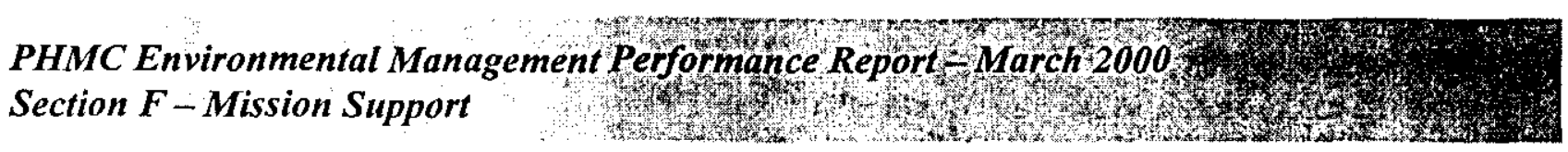

\section{COST VARIANCE ANALYSIS: (+1.2M)}

WBS/PBS

\subsection{2/OT01} lining the vendor support for Site Level Analysis and Modeling. The vendor has performed the majority of their workscope during the first 4 months of the fiscal year. It is also caused by accrual reversals for which no offsetting payments were entered into the financial tracking system. The FY 1999 accruals were inadvertently reversed prior to actual charges hitting. A smaller portion of the variance is attributed to less than anticipated activity in some level-ofeffort activities. The remainder of the favorable variance is primarily due to Chemical Management contract costs to date being less than anticipated in the Environmental Compliance Program.

Corrective Action: The only Corrective Action requirement is the FY 1999 commitments will be re-accrued until actual charges are received

\section{SCHEDULE VARIANCE ANALYSIS: $(-\$ 0.4)$}

\subsection{2/OT01}

Mission Support

The $\$ 0.4$ million (eight percent) unfavorable schedule variance is within acceptable reporting thresholds.

\section{Baseline Change Requests Currently in Process $(\$ 000)$}

\begin{tabular}{|c|c|c|c|c|c|c|c|c|c|}
\hline $\begin{array}{l}\text { PROJECT } \\
\text { CHANGE } \\
\text { NUMBER }\end{array}$ & $\begin{array}{l}\text { DATE } \\
\text { ORIGIN. }\end{array}$ & BCR TITLE & $\begin{array}{l}\text { FYOO COST } \\
\text { IMPACT } \$ 000\end{array}$ & $\mathrm{SCH}$ & TECH & $\begin{array}{l}\text { DATE } \\
\text { TO CCB }\end{array}$ & $\begin{array}{c}\text { CCB } \\
\text { APR'VD }\end{array}$ & $\begin{array}{c}\text { RL } \\
\text { APR'VD }\end{array}$ & $\begin{array}{l}\text { CURRENT } \\
\text { STATUS }\end{array}$ \\
\hline SPI-2000-002 & $10 / 22 / 99$ & FY 1999 Carryover Scope & $\$ 248$ & $\mathrm{X}$ & $\mathrm{X}$ & $2 / 3 / 00$ & $2 / 3 / 00$ & & In process \\
\hline SPI-2000-006 & $2 / 17 / 00$ & $\begin{array}{l}\text { Modeling Tool \& IPL Module } \\
\text { Scope Additions FY } 2000\end{array}$ & $\$ 117$ & $\mathrm{X}$ & $\mathrm{X}$ & $2 / 17 / 00$ & $2 / 17 / 00$ & & In Process \\
\hline PSR-2000-001 & & $\begin{array}{l}\text { Alignment of Budget/Scope } \\
\text { to Funding Allocation and } \\
\text { Incorporation of FY } 1999 \\
\text { Carry Over }\end{array}$ & $\$ 193$ & $\mathrm{X}$ & & & & & \\
\hline PSR-2000-003 & & $\begin{array}{l}\text { Adjust project baseline to reflect } \\
\text { repricing changes to Basis of } \\
\text { Estimate, FY } 1999 \text { SAR } \\
\text { Implementation in FY } 2000 \text { and } \\
\text { incorporation of carry over. }\end{array}$ & $\$ 138$ & $\mathrm{X}$ & $\mathrm{X}$ & & & & \\
\hline \multicolumn{10}{|c|}{ ADVANCE WORK AUTHORIZATIONS } \\
\hline & & Nothing to report. & & & & & & & \\
\hline
\end{tabular}


PHMC Environmental Management Performance Report 1 March 2000

Section F-Mission Support

Milestone ACHievement

\begin{tabular}{|c|c|c|c|}
\hline \multicolumn{4}{|c|}{ Tri-Party Agreement / EA Milestones } \\
\hline Number & Milestone Title & Status & Complete \\
\hline ECP-00-302 & $\begin{array}{l}\text { RCRA Permit Class } 1 \text { Mod Notification } \\
\text { Quarter } 1 \text { (For Year 2000-2046) }\end{array}$ & $10 / 01 / 1999$ & $09 / 30 / 1999$ \\
\hline ECP-00-702 & $\begin{array}{l}\text { RCRA RPTS/DOCS Closure/Post Closure } \\
\text { Cost Est. to RL }\end{array}$ & $10 / 22 / 1999$ & $10 / 06 / 1999$ \\
\hline ECP-00-901 & $\begin{array}{l}\text { Issue Quarterly NESHAP Status RPT to } \\
\text { RL for EPA }\end{array}$ & $10 / 22 / 1999$ & $10 / 20 / 1999$ \\
\hline EPC-00-306 & $\begin{array}{l}\text { Annual Asbestos Notification of Intent } \\
\text { (For Year 2000-2046) }\end{array}$ & $12 / 31 / 1999$ & $12 / 14 / 1998$ \\
\hline $\mathrm{ECP}-00-303$ & $\begin{array}{l}\text { RCRA Permit Class } 1 \text { Mod Notification } \\
\text { Quarter } 2 \text { (For FY 2000-2046) }\end{array}$ & $01 / 01 / 2000$ & $12 / 16 / 1999$ \\
\hline ECP-00-902 & $\begin{array}{l}\text { Issue Quarterly NESHAP Status RPT } \\
\text { to RL for EPA }\end{array}$ & $01 / 22 / 2000$ & $01 / 17 / 2000$ \\
\hline ECP-00-410 & $\begin{array}{l}\text { Annual PTRAEU Report to DOE-RL } \\
\text { (For FY 200-2046) }\end{array}$ & $02 / 01 / 2000$ & $\begin{array}{c}\text { overdue } \\
\text { pending } \mathrm{BCR}\end{array}$ \\
\hline ECP-00-701 & Annual Noncompliance Report to RL & $02 / 24 / 2000$ & $02 / 09 / 2000$ \\
\hline ECP-00-503 & $\begin{array}{l}1999 \text { Hanford Site Annual Dangerous } \\
\text { Waste Report (FY 2000-2046) }\end{array}$ & $02 / 22 / 2000$ & $02 / 22 / 2000$ \\
\hline ECP-00-501 & $\begin{array}{l}\text { Tier II Emergency \& Hazardous } \\
\text { Chemical Inventory }\end{array}$ & $02 / 22 / 2000$ & $02 / 23 / 2000$ \\
\hline $\mathrm{ECP}-00-003$ & $\begin{array}{l}\text { Biennial Assess. Of Info. \& Data } \\
\text { Access Needs EPA/ECO (2000-2046) }\end{array}$ & $03 / 31 / 2000$ & \\
\hline ECP-00-801 & $\begin{array}{l}\text { Transmit EIS/ODIS Data to INEEL } \\
\text { (FY 2000-2046) }\end{array}$ & $04 / 01 / 2000$ & \\
\hline ECP-00-802 & $\begin{array}{l}\text { Non-Radioactive Airborne Emissions } \\
\text { Report (FY 2000-2046) }\end{array}$ & $04 / 01 / 2000$ & \\
\hline ECP-00-304 & $\begin{array}{l}\text { RCRA Permit Class I Mod Notification } \\
\text { Quarter } 3 \text { (For FY 2000-2046) }\end{array}$ & $04 / 02 / 2000$ & \\
\hline ECP-00-904 & $\begin{array}{l}\text { Issue Quarterly NESHAP Status Report } \\
\text { To RL for EPA }\end{array}$ & $04 / 21 / 2000$ & \\
\hline ECP-00-803 & $\begin{array}{l}\text { Issue Annual Radionuclide Air Emissions } \\
\text { Report (For FY 2000-2046) }\end{array}$ & $06 / 15 / 2000$ & \\
\hline ECP-00-502 & $\begin{array}{l}\text { EPCRA Section } 313 \text { Toxic Chemical } \\
\text { Release Inventory }\end{array}$ & $06 / 24 / 2000$ & \\
\hline ECP-00-504 & Annual Document Log - June & $06 / 24 / 2000$ & \\
\hline ECP-00-305 & $\begin{array}{l}\text { RCRA Permit Class I Mod Notification } \\
\text { Quarter } 4 \text { (For FY 2000-2046) }\end{array}$ & $07 / 02 / 2000$ & \\
\hline
\end{tabular}




\begin{tabular}{|lll|}
\hline ECP-00-505 & PCB Annual Report - July & $07 / 08 / 2000$ \\
ECP-00-507 & Annual LDR Report (M-26-01) & $04 / 23 / 2000$ \\
ECP-00-906 & Issue Quarterly NESHAP Status & $07 / 28 / 2000$ \\
& Report to RL for EPA & $09 / 21 / 2000$ \\
ECP-00-703 & Coordinate RCRA Pipe Mapping and & \\
& Marking (For FY 2000-2046) & $09 / 30 / 2000$ \\
ECP-00-301 & $\begin{array}{l}\text { RCRA General Facility Inspections } \\
\text { (For FY 2000-2046) }\end{array}$ \\
\hline & \\
\hline
\end{tabular}

\section{MISSION SUPPORT - WBS 1.8 MILESTONE ACHIEVEMENT}

\begin{tabular}{|c|c|c|c|c|c|c|c|c|}
\hline \multirow[b]{2}{*}{ MILESTONE TYPE } & \multicolumn{4}{|c|}{ FISCAL YEAR-TO-DATE } & \multicolumn{3}{|c|}{ REMAINING SCHEDULED } & \multirow[b]{2}{*}{$\begin{array}{c}\text { TOTAL } \\
\text { FY } \\
2000\end{array}$} \\
\hline & $\begin{array}{c}\text { Completed } \\
\text { Early }\end{array}$ & $\begin{array}{c}\text { Completed } \\
\text { On } \\
\text { Schedule }\end{array}$ & $\begin{array}{c}\text { Completed } \\
\text { Late }\end{array}$ & Overdue & $\begin{array}{c}\text { Forecast } \\
\text { Early }\end{array}$ & $\begin{array}{c}\text { Forecast } \\
\text { On } \\
\text { Schedule }\end{array}$ & $\begin{array}{c}\text { Forecast } \\
\text { Late }\end{array}$ & \\
\hline Enforceable Agreement & 4 & 0 & 0 & 0 & $\overline{0}$ & 25 & 0 & 29 \\
\hline DOE-HQ & 0 & 0 & 0 & 0 & 0 & 1 & 0 & 1 \\
\hline $\mathrm{RL}$ & 3 & 0 & 1 & 0 & 0 & 21 & 0 & 25 \\
\hline Total Project & 7 & 0 & 1 & 0 & 0 & 47 & 0 & 55 \\
\hline
\end{tabular}

\section{MILESTONE EXCEPTION REPORT}

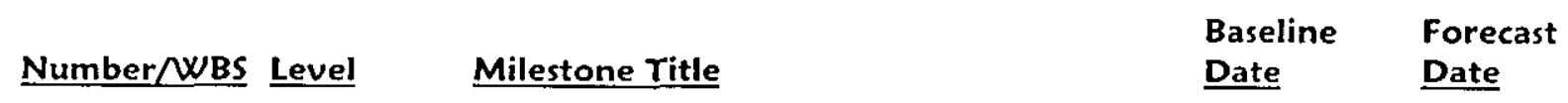

\section{OVERDUe - 0}

\section{FY 1999 OVERDUE - 0}

\section{Performance Objectives}

Nothing to report.

\section{KEY INTEGRATION ACTIVITIES}

Nothing to report. 

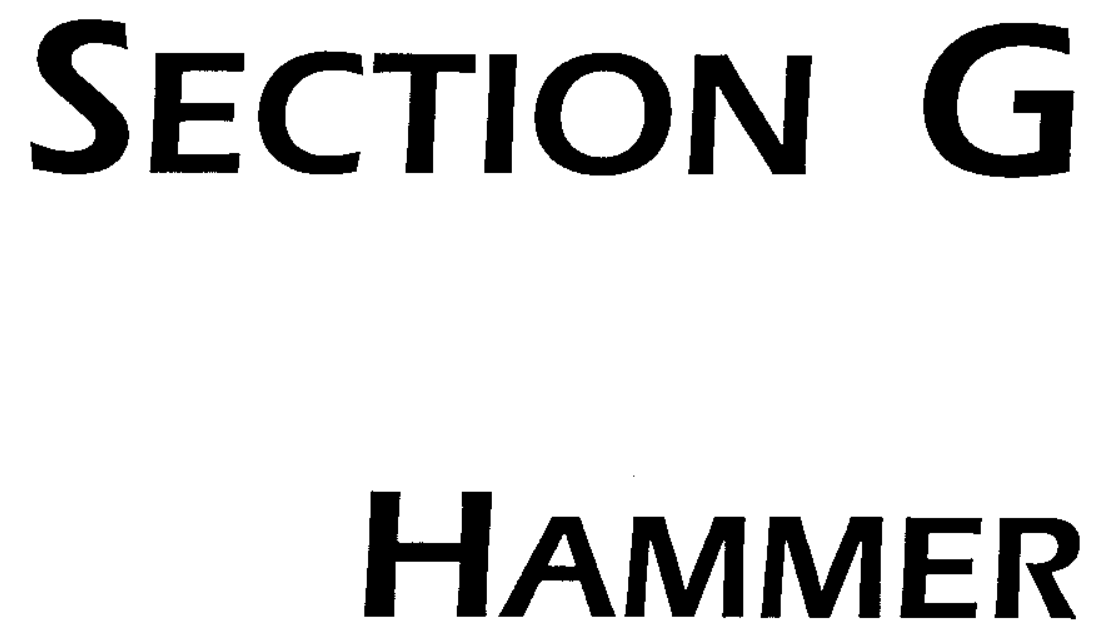

PROGRAM MANAGERS

\author{
J. E. Ollero, RL \\ Phone: (509) 376-3825 \\ K. A. McGinnis, FH \\ Phone: (509) 376-9403
}




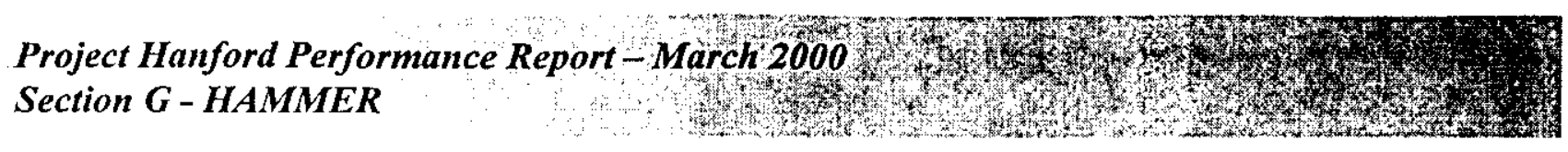

\section{SUMMARY}

The Hazardous Materials Management and Emergency Response (HAMMER) mission area consists of the HAMMER project, WBS 1.9.1.1, Project Baseline Summary (PBS) HM01.

Volpentest HAMMER's first priority is to deliver hands-on training to the Hanford workforce. During January one hundred thirty-five classes were conducted at the Volpentest HAMMER facility, for a total of 2,206 Hanford site student days. Highest attended health and safety classes included Hazardous Waste Operations, Respiratory Protection, Radiation Worker II Requalification, Basic Medic First Aid and Fire Extinguisher Training. Overall satisfaction, rated on a scale of 1 to 5 based on level one evaluations, for the month of January: Course Content 4.50, Instructor(s) 4.62, and Facility 4.50.

A total of four Hanford site Emergency Preparedness training courses were presented during January with a total of 68 students receiving training. Emergency Preparedness classes presented included the Hanford Incident Command System, Building Emergency Director, and Building Warden training courses.

Baseline Change Request \#HMR-2000-001 was approved by DOE-RL on January 28, 2000. This change request incorporates critical FY 1999 carryover workscope and additional new FY 2000 workscope into the baseline.

Three non-DOE customers utilized the Volpentest HAMMER facility for training activities, via the established HAMMER User Agreement process. The customers included OSHA - Office of Training and Education, Allied Technology Group and the Metro Drug Task Force. In addition HAMMER sponsored a Suspect/Counterfeit Items (S/CI) teleconference and a National Transportation Program (NTP) televideo users group training session. These training activities generated approximately $\$ 7,400$ of revenue for HAMMER. Generating revenue is included in the FY 2000 MYWP workscope activities for HAMMER, and will assist in reducing costs to DOE of providing site training.

Milestone performance (EA, DOE-HQ, and RL) shows that there are no milestones due fiscal year-to-date.

\section{ACCOMPLISHMENTS}

- Trained 2,206 Hanford site student days at HAMMER.

- Presented four Hanford site Emergency Preparedness training courses.

- DOE-RL approves Baseline Change Request \#HMR-2000-001.

- Three non-DOE customers utilized the Volpentest HAMMER facility for training activities. In addition HAMMER sponsored a S/CI teleconference and an NTP televideo users group training session. 
Hammer currently has not status to report in the areas of ISMS Status, Breakthroughs and Opportunities for Improvement.

\section{UPCOMING ACTIVITIES}

- CBC/HAMMER Fire Recruit Academy - March 27, 2000 - June 17, 2000.

- OSHA Training Institute Class, Excavation, Trenching and Soil Mechanics March 28-31,2000

\section{Cost Performance (\$M):}

\begin{tabular}{|l|c|c|c|}
\hline & BCWP & ACWP & VARIANCE \\
\hline HAMMER & $\$ 1.7$ & $\$ 1.6$ & $\$ 0.1$ \\
\hline
\end{tabular}

The cost variance is insignificant.

\section{SChedule Performance (\$M):}

\begin{tabular}{|l|c|c|c|}
\hline & BCWP & BCWS & VARIANCE \\
\hline HAMMER & $\$ 1.7$ & $\$ 1.7$ & $\$ 0.0$ \\
\hline
\end{tabular}

The schedule variance is insignificant.

\section{WBS 1.9 \\ FY 2000 Cost/SChedule Performance - All Fund Types Cumulative to Date Status - $(\$ 000)$}

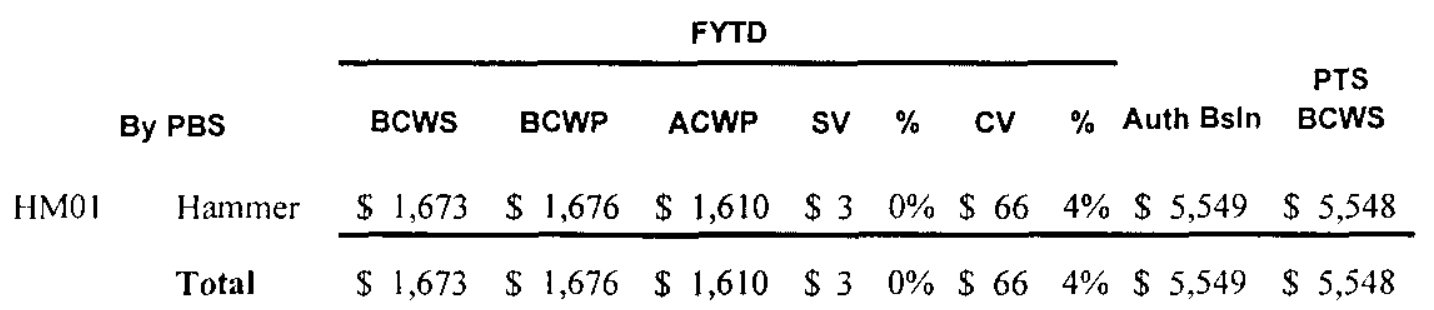


Project Hanford Performance Report - March 2000 Section G-HAMMER

\section{WBS 1.9}

\section{Cost/Schedule Performance Indices \\ (JANUARY 2000 AND FYTD)}

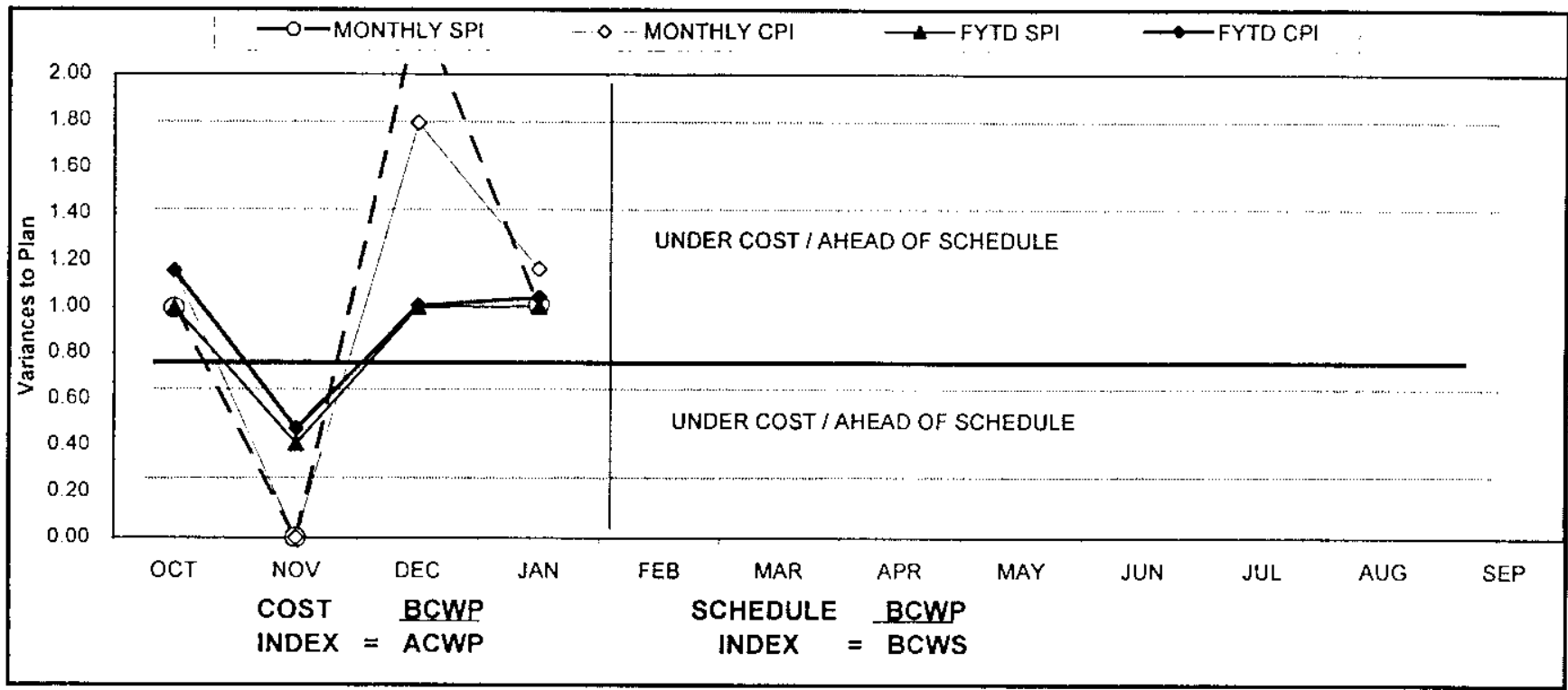

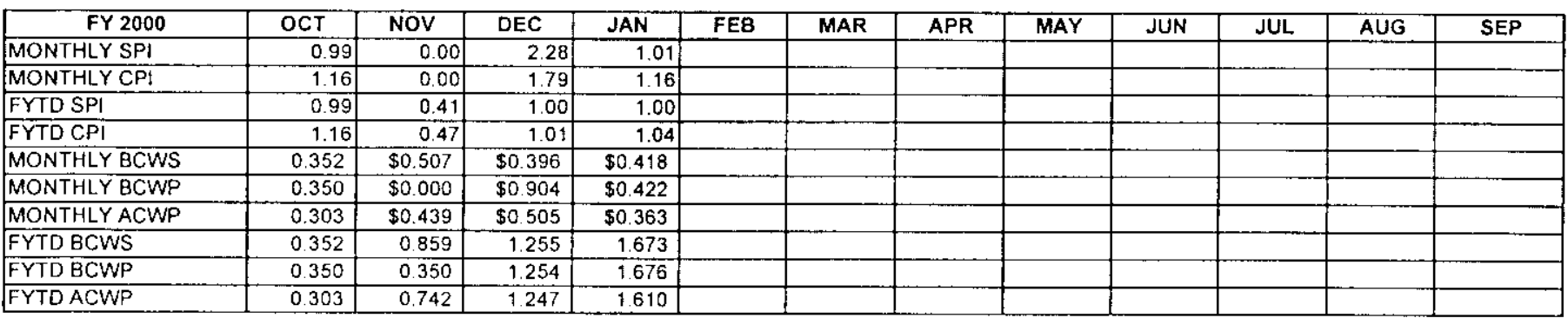

\section{ISSUES}

Nothing to report.

\section{COST VARIANCE ANALYSIS: $(\$ 0.0 \mathrm{M})$}

\section{WBS/PBS TITLE}

\subsubsection{1/HM01 HAMMER}

Description and Cause: The variance is within thresholds.

Impact: None.

Corrective Action: None. 
Project Hanford Performance Report - March 2000

Section G - HAMMER

\section{SCHEDULE VARIANCE ANALYSIS: (\$0.0M)}

WBS $\quad \underline{T I T L E}$

1.9.1.1/HM01 HAMMER

Description and Cause: There is no variance.

Impact: None.

Corrective Action: None.

Baseline Change Requests Currently in Process $(\$ 000)$

\begin{tabular}{|c|c|c|c|c|c|c|c|c|c|}
\hline $\begin{array}{l}\text { PROJECT } \\
\text { CHANGE } \\
\text { NUMBER }\end{array}$ & $\begin{array}{c}\text { DATE } \\
\text { ORIGIN. }\end{array}$ & BCR TITLE & $\begin{array}{l}\text { FYOO COST } \\
\text { IMPACT } \$ 000\end{array}$ & $\mathrm{SCH}$ & $\mathrm{TECH}$ & $\begin{array}{c}\text { DATE TO } \\
\text { CCB }\end{array}$ & $\begin{array}{c}\text { CCB } \\
\text { APR'VD }\end{array}$ & $\begin{array}{c}R L \\
\text { APR'VD }\end{array}$ & $\begin{array}{l}\text { CURRENT } \\
\text { STATUS }\end{array}$ \\
\hline & & Nothing to report & & & & & & & \\
\hline \multicolumn{10}{|c|}{ ADVANCE WORK AUTHORIZATIONS } \\
\hline & & Nothing to report & & & & & & & \\
\hline
\end{tabular}

\section{HAMMER - WBS 1.9 \\ MILESTONE ACHIEVEMENT}

\begin{tabular}{|c|c|c|c|c|c|c|c|c|}
\hline \multirow[b]{2}{*}{ MILESTONE TYPE } & \multicolumn{4}{|c|}{ FISCAL YEAR-TO-DATE } & \multicolumn{3}{|c|}{ REMAINING SCHEDULED } & \multirow[b]{2}{*}{$\begin{array}{l}\text { TOTAL } \\
\text { FY } 2000\end{array}$} \\
\hline & $\begin{array}{c}\text { Completed } \\
\text { Early }\end{array}$ & $\begin{array}{c}\text { Completed } \\
\text { On Schedule }\end{array}$ & $\begin{array}{c}\text { Completed } \\
\text { Late }\end{array}$ & Overdue & $\begin{array}{c}\text { Forecast } \\
\text { Early }\end{array}$ & $\begin{array}{c}\text { Forecast On } \\
\text { Schedule }\end{array}$ & $\begin{array}{l}\text { Forecast } \\
\text { Late }\end{array}$ & \\
\hline Enforceable Agreemen & 0 & 0 & 0 & $\underline{0}$ & 0 & 0 & 0 & 0 \\
\hline DOE-HQ & 0 & 0 & 0 & $\overline{0}$ & 0 & 0 & 0 & 0 \\
\hline $\overrightarrow{\mathrm{RL}}$ & 0 & 0 & 0 & 0 & 0 & 5 & 0 & 5 \\
\hline Total Project & 0 & 0 & 0 & 0 & 0 & 5 & 0 & 5 \\
\hline
\end{tabular}

\begin{tabular}{|l|}
\hline Tri-Party Agreement / EA Milestones \\
\hline Nothing to report \\
\hline \\
\hline DNFSB Commitments \\
\hline Nothing to report \\
\hline
\end{tabular}

\section{MILESTONE EXCEPTION REPORT}

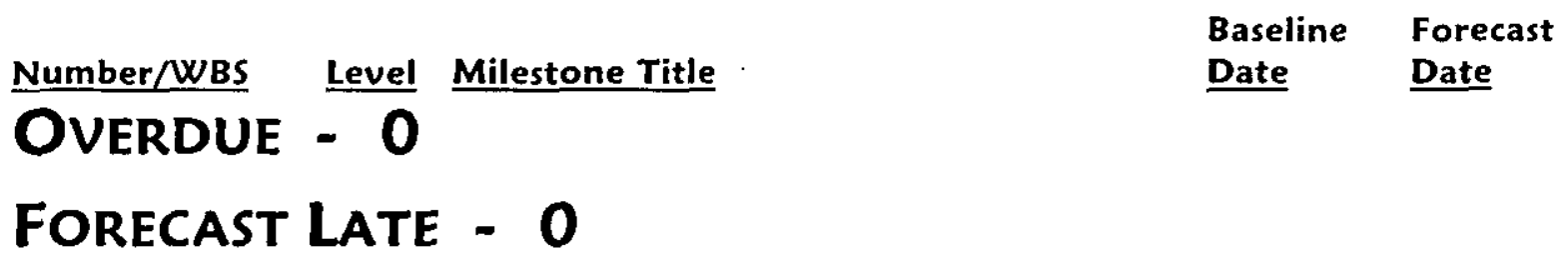



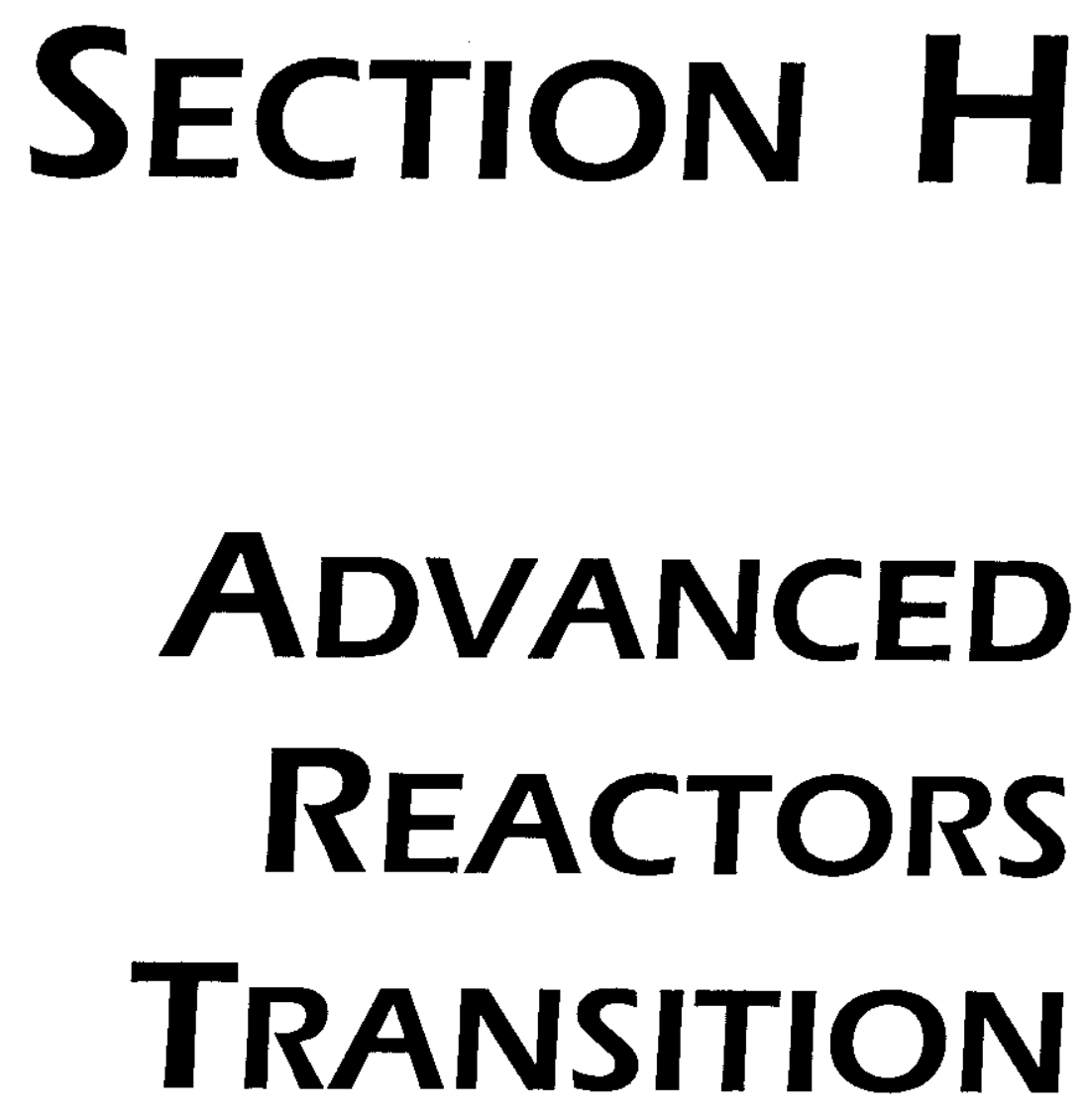

Project Managers

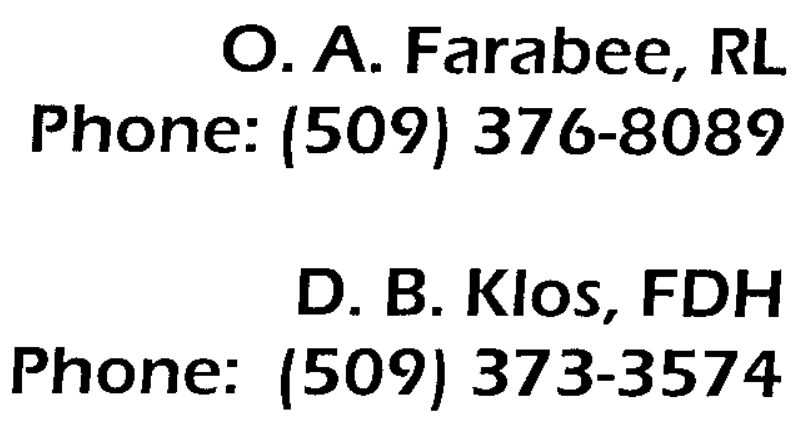

DOE/RL-99-83, Rev. 2 


\section{SUMMARY}

The Advanced Reactors Transition (ART) Program, WBS 1.12.1.1, PBS RL-TP11, consists of the 309 Building and the Nuclear Energy (NE) Legacies activities

In January the ART mission area technical accomplishments included continued surveillance and maintenance activities on the 309 Building and NE Legacy facilities. Repairs were made to lights on the 309 Building containment dome polar crane, correcting a problem noted during an annual preventive maintenance inspection. NE Legacies deactivation activities included continued cleaning of sodium residue from T Plant tank TK-3, using the moist nitrogen process. Concentrated sodium hydroxide generated by the cleaning activity is being drained into drums for shipment to the Treated Effluent Disposal Facility (TEDF) as product. TK-3 tank cleaning is anticipated to be completed in February 2000.

Fiscal-year-to-date milestone performance (EA, DOE-HQ, and RL) shows that there are no milestones due.

\section{ACCOMPLISHMENTS}

- Continued surveillance and maintenance activities on 309 Building and NE legacies.

- Good progress continued on cleaning sodium residuals from a tank from the 221-T Building using the moist nitrogen process. 


\section{SAFETY}

Specific safety data is not available at this time. However, safety data for ART is included in the statistics for the FFTF and RCP Projects.

\section{CONDUCT OF OPERATIONS / ISMS STATUS}

Specific Conduct of Operations information is not available at this time. However, all conduct of operations data for ART is included in the FFTF and RCP Projects.

\section{ISMS STATUS}

The ISMS Internal Readiness Review Plan was approved; a team was formed to assess the five functional areas in accordance with the DOE Team Leaders Handbook on conducting ISMS verifications. Training was provided to the team on the methodology for this management assessment.

\section{BREAKTHROUGHS / OPPORTUNITIES FOR IMPROVEMENT Breakthroughs}

No status to report at this time.

\section{Opportunities for Improvement}

No status to report at this time.

\section{UPCOMING ACTIVITIES}

Complete the cleaning of sodium residue from T Plant tank TK-3.

Initiate cleaning of the sodium potassium (Nak) residuals from the $337 \mathrm{~B}$ Building cold trap cooling loop. 


\section{Cost Performance ( $\$ M)$ :}

\begin{tabular}{|l|c|c|c|}
\hline & BCWP & ACWP & VARIANCE \\
\hline Advanced Reactors Transition & $\$ 0.4$ & $\$ 0.4$ & $+\$ 0.0$ \\
\hline
\end{tabular}

There is no significant cost variance.

\section{Schedule Performance ( $\$ M)$ :}

\begin{tabular}{|l|c|c|c|}
\hline & BCWP & BCWS & VARIANCE \\
\hline Advanced Reactors Transition & $\$ 0.4$ & $\$ 0.4$ & $+\$ 0.0$ \\
\hline
\end{tabular}

There is no significant schedule variance.

Fy 2000 Cost/Schedule Performance - All Fund Types ADVANCED REACTORS TRANSITION WBS 1.12 Cumulative to Date Status - $(\$ 000)$ FYTD

By PBS

\begin{tabular}{lllllllll}
\hline BCWS & BCWP ACWP & SV & $\%$ & $\mathrm{CV}$ & $\%$ & BAC EAC FUJECTED \\
FUNDING
\end{tabular}

TP11 Advanced Reactors Total

\begin{tabular}{|c|c|c|c|c|c|c|c|c|c|c|}
\hline 0.4 & 0.4 & 0.4 & 0.0 & $3 \%$ & -0 & $-1 \%$ & 1.3 & 0 & 0 & Green \\
\hline \multirow[t]{2}{*}{0.4} & 0.4 & 0.4 & 0.0 & $3 \%$ & -0 & $-1 \%$ & 1.3 & 0 & 0 & \\
\hline & & & & & & & & & & Green \\
\hline
\end{tabular}




\section{ADVANCED REACTORS TRANSITION (ART) \\ COST/SCHEDUle PERformance INDICES \\ (JANUARY 2000 AND FYTD)}

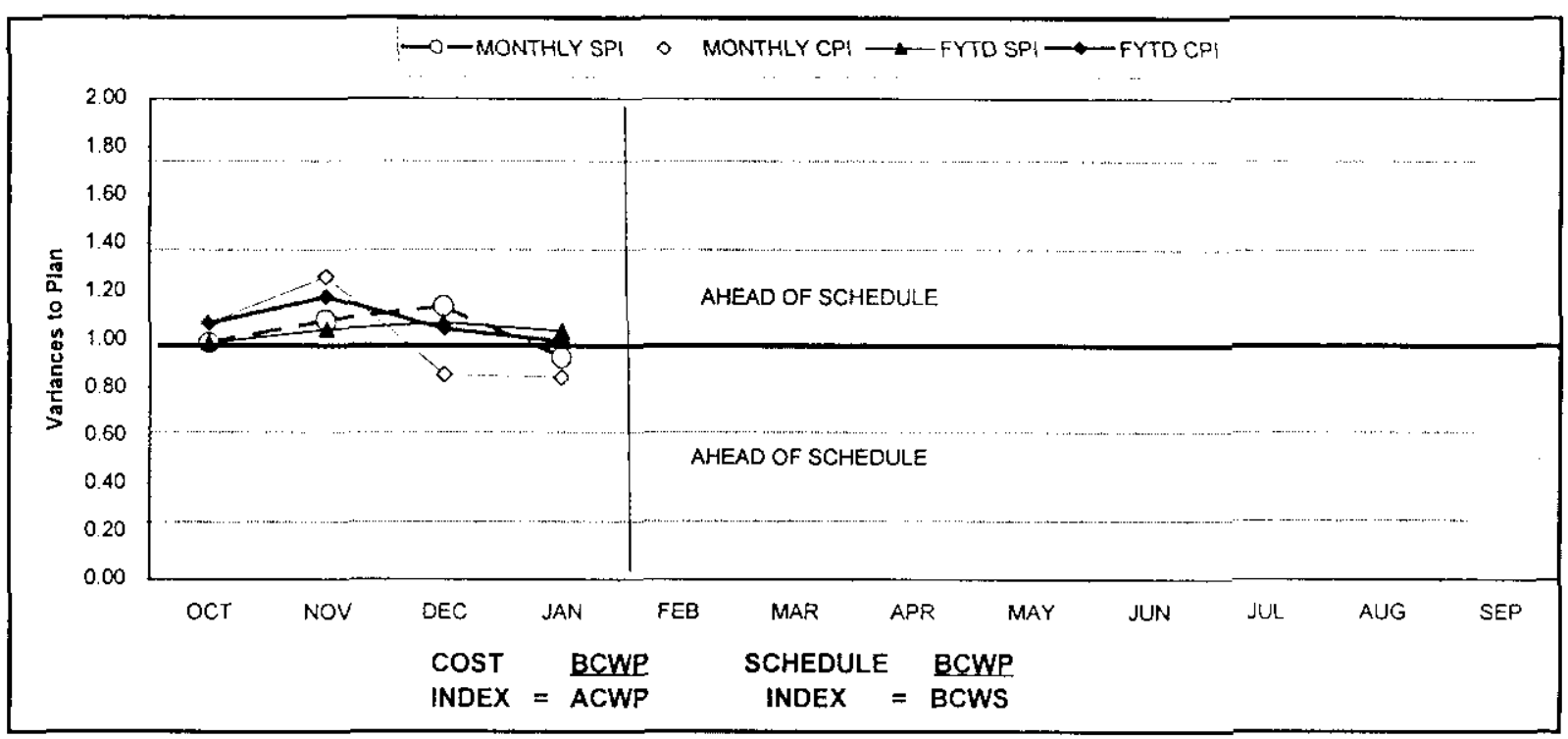

\begin{tabular}{|c|c|c|c|c|c|c|c|c|c|c|c|c|}
\hline FY 2000 & OCT & NOV & DEC & JAN & FEB & MAR & APR & MAY & JUN & JUL & AUG & SEP \\
\hline MONTHLY SPI & 0.99 & 1.08 & 1,14 & 0.92 & & & & & & & & \\
\hline MONTHLY CPI & 1.07 & 1.26 & 0.85 & 0.84 & & & & & & & & \\
\hline FYTD SPI & 0.99 & 1.04 & 1.07 & 1.03 & & & & & & & & \\
\hline FYTD CPI & 1.07 & 1.18 & 1.05 & 0.99 & & & & & & & & \\
\hline MONTHLY BCWS & $\$ 79.0$ & $\$ 1130$ & $\$ 88.0$ & $\$ 93.0$ & & & & & & & & \\
\hline MONTHLY BCWP & $\$ 78.0$ & $\$ 122.0$ & $\$ 100.0$ & $\$ 86.0$ & & & & & & & & \\
\hline MONTHLY ACWP & $\$ 73.0$ & $\$ 97.0$ & $\$ 117.0$ & $\$ 102.0$ & & & & & & & & \\
\hline FYTO BCWS & $\$ 79.0$ & $\$ 192.0$ & $\$ 2800$ & $\$ 373.0$ & & & & & & & & \\
\hline FYTD BCWP & $\$ 78.0$ & $\$ 200.0$ & $\$ 3000$ & $\$ 386.0$ & & & & & & & & \\
\hline FYTD ACWP & $\$ 73.0$ & $\$ 1700$ & $\$ 287.0$ & $\$ 3890$ & & & & & & & & \\
\hline
\end{tabular}

\section{ISSUES}

Issue: Low overall site priority has resulted in limited project funding.

Impacts(s): The project deactivation schedule has lengthened.

Corrective Action: Increase future funding to accelerate project completion. 
PHMC Environmental Management Performance Report 4 arch 2000

Section $H$-Advanced Reactors Transition $(A R T)$

\section{COST VARIANCE ANALYSIS: $(+\$ 0.0 M)$}

\section{WBS/PBS}

$1.12 / \mathrm{TP} 11$

Description

Impact: None.

Corrective Action: None.
Title

Advanced Reactors Transition

\section{SCHEDUle VARIANCE ANALYSIS: $(+\$ 0.0 \mathrm{M})$}

\section{WBS/PBS Title}

$1.12 / \mathrm{TP} 11$

Advanced Reactors Transition

Description and Cause: None.

Impact: None.

Corrective Action: None.

\section{Baseline Change Requests Currently in Process (\$000)}

Baseline Change Requests Currently in Process (\$000)

\begin{tabular}{|c|c|c|c|c|c|c|c|c|c|}
\hline $\begin{array}{c}\text { PROJECT } \\
\text { CHANGE } \\
\text { NUMBER }\end{array}$ & $\begin{array}{c}\text { DATE } \\
\text { ORIGIN. }\end{array}$ & BCR TITLE & $\begin{array}{c}\text { FY00 COST } \\
\text { IMPACT \$000 }\end{array}$ & SCH & TECH & $\begin{array}{c}\text { DATE TO } \\
\text { CCB }\end{array}$ & $\begin{array}{c}\text { CCB } \\
\text { APR'VD }\end{array}$ & $\begin{array}{c}\text { RL } \\
\text { APR'VD }\end{array}$ & $\begin{array}{c}\text { CURRENT } \\
\text { STATUS }\end{array}$ \\
\hline ART-2000-003 & $02 / 11 / 2000$ & FY 1999 Carry OVer Funds and Scope & 218 & $X$ & $X$ & $02 / 12 / 2000$ & Pending \\
\hline & ADVANCE WORK AUTHORIZATIONS & & \\
\hline
\end{tabular}


PHMC Environmental Management Performance Report $-\mathrm{W}_{\text {arrch }} 2000$

Section $\boldsymbol{H}-$ Advanced Reactors Transition (ART)

\section{AdVANCED REACTORS TRANSITION - WBS 1.2 Milestone ACHIEVEMENT}

Fiscal-year-to-date milestone performance (EA, DOE-HQ, and RL) shows that there are no milestones due.

\begin{tabular}{|lc|}
\hline & Tri-Party Agreement / EA Milestones \\
\hline Nothing to report \\
\hline & DNFSB Commitments \\
\hline Nothing to report. \\
\hline & DOE-HQ \\
\hline Nothing to report. & \\
\hline
\end{tabular}

\section{MILESTONE EXCEPTION REPORT}

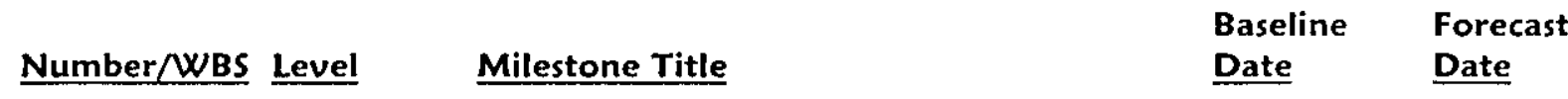

\section{OVERDUe - 0}

FORECAST LATE - 0

FY 1999 OVERDUE - 0

\section{Performance Objectives}

Nothing to report.

\section{KEY INTEGRATION ACTIVITIES}

Nothing to report. 
PHMC Environmental Management Performance Report - March 2000

Section I-EM - 50
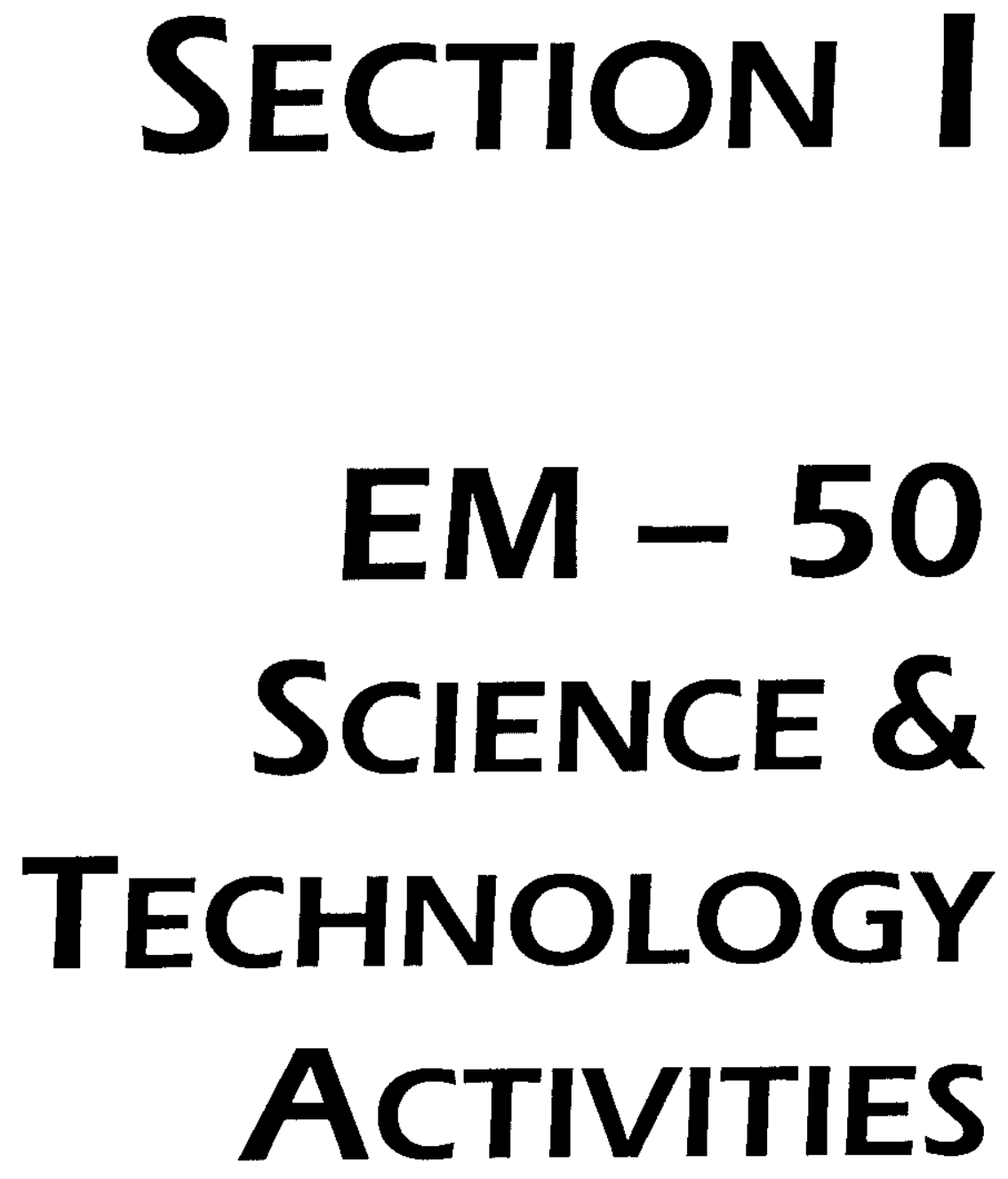

DOE/RL-99-83, Rev. 2 
PHMC Environmental Management Performance Report March 2000

Section I - EM - 50

EM-50

MILESTONE ACHIEVEMENT

\begin{tabular}{|c|c|c|c|c|c|c|c|c|}
\hline \multirow[b]{2}{*}{ MILESTONE TYPE } & \multicolumn{4}{|c|}{ FISCAL YEAR-TO-DATE } & \multicolumn{3}{|c|}{ REMAINING SCHEDULED } & \multirow[b]{2}{*}{$\begin{array}{l}\text { TOTAL } \\
\text { FY } 2000\end{array}$} \\
\hline & Completed Early & $\begin{array}{c}\text { Completed On } \\
\text { Schedule }\end{array}$ & $\begin{array}{l}\text { Completed } \\
\text { Late }\end{array}$ & Overdue & $\begin{array}{c}\text { Forecast } \\
\text { Early }\end{array}$ & $\begin{array}{c}\text { Forecast } \\
\text { On } \\
\text { Schedule }\end{array}$ & $\begin{array}{c}\text { Forecast } \\
\text { Late }\end{array}$ & \\
\hline Enforceable Agreement & 0 & 0 & 0 & 0 & 0 & 0 & 0 & 0 \\
\hline DOE-HQ & of & of & 0 & 0 & of & 1 & 0 & 1 \\
\hline $\mathrm{RL}$ & of & of & 0 & 3 & 0 & 1 & 0 & \\
\hline Total Project & 0 & 0 & 0 & 3 & 0 & 2 & 0 & 5 \\
\hline
\end{tabular}




\section{EM-50 Exceptions}

$\begin{array}{lll}\text { Number Level Milestone Title } & \text { BASELINE ForECAST } \\ & \underline{\text { Date }} & \underline{\text { Date }}\end{array}$

\section{Overdue - 3}

009DD61/3 RL Award Contract for Robotic Work 10/15/99 2/10/00 2.1.1 (AMT) Platform

Cause: RFP was sent out to all potential vendors. Review of submittals has delayed issuance of the contract.

Impact: None

Corrective Action: The contract will be awarded in February 2000.

49MW21/C-2 RL Produce Report Mapping the Matrix Space 11/15/99 Proposed 2.1.1 (AMT) in Hanford Waste Boxes Deletion

Cause: Activities at WRAP were focused on preparing shipments to WIPP.

Impact: None

Corrective Action: Funding for this TTP was returned to the Mixed Waste Focus Area. This task is cancelled.

49MW21/B-4 RL Issue Software Test Reports 12/01/99 Proposed 2.1.1 (AMT) in Hanford Waste Boxes Deletion

Cause: Activities at WRAP were focused on preparing shipments to WIPP.

Impact: None

Corrective Action: Funding for this TTP was returned to the Mixed Waste Focus Area. This task is cancelled. 
PHMC Environmental Management Performance Report-March 2000

Section J-National Programs
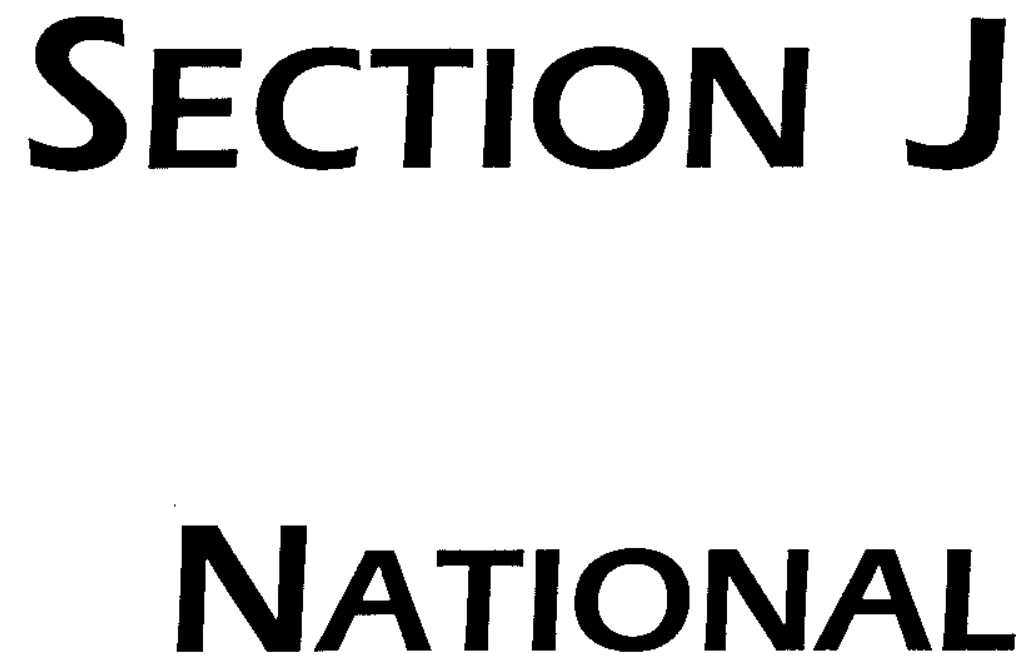

PROGRAMS

DOE/RL-99-83, Rev. 2 


\section{Introduction to National Programs}

DOE EM is responsible for a variety of National Programs. DOE-HQ typically provides operations policy and programmatic guidance to one or more field office that serve as lead for individual programs. FH currently supports the following National Programs: Transportation and Packaging (PBS OT02), Pollution Prevention and Waste Minimization (PBS WM07), and Emergency Preparedness (PBS OT06).

Transportation and Packaging provides full-service transportation and packaging capabilities. Packaging services for radioactive and hazardous cargo is provided, including regulatory safetybasis documentation, certification, and licensing. Packaging plans and logistical studies for major shipping campaigns are also provided, as well as approved training courses in transportation safety and waste management. Transportation and traffic logistics management, engineering and operational support to offsite customers, carrier selection and evaluation, automated transportation management systems used by the U.S. Department of Energy (DOE) complex and commercial vendors, and international transport of hazardous and radioactive packages are other services provided.

Pollution Prevention and Waste Minimization (P2/WMin) coordinates the development and implementation of a Hanford Site P2/WMin Program to comply with Federal, state, and DOE directives. The program's purpose is to achieve Site objectives through effective and efficient methodologies tailored to generator activities and operations.

The Emergency Preparedness workscope is under the direction of the DOE National Transportation Program. This training program (coordinated through HAMMER) offers consistent training necessary for the DOE complex to meet the changing requirements for safe and compliant transport of hazardous materials. 
National Programs

WBS 1.11

FY 2000 COST/SCHEDULE PERFORMANCE - ALL FUND TYPES

Cumulative to Date Status
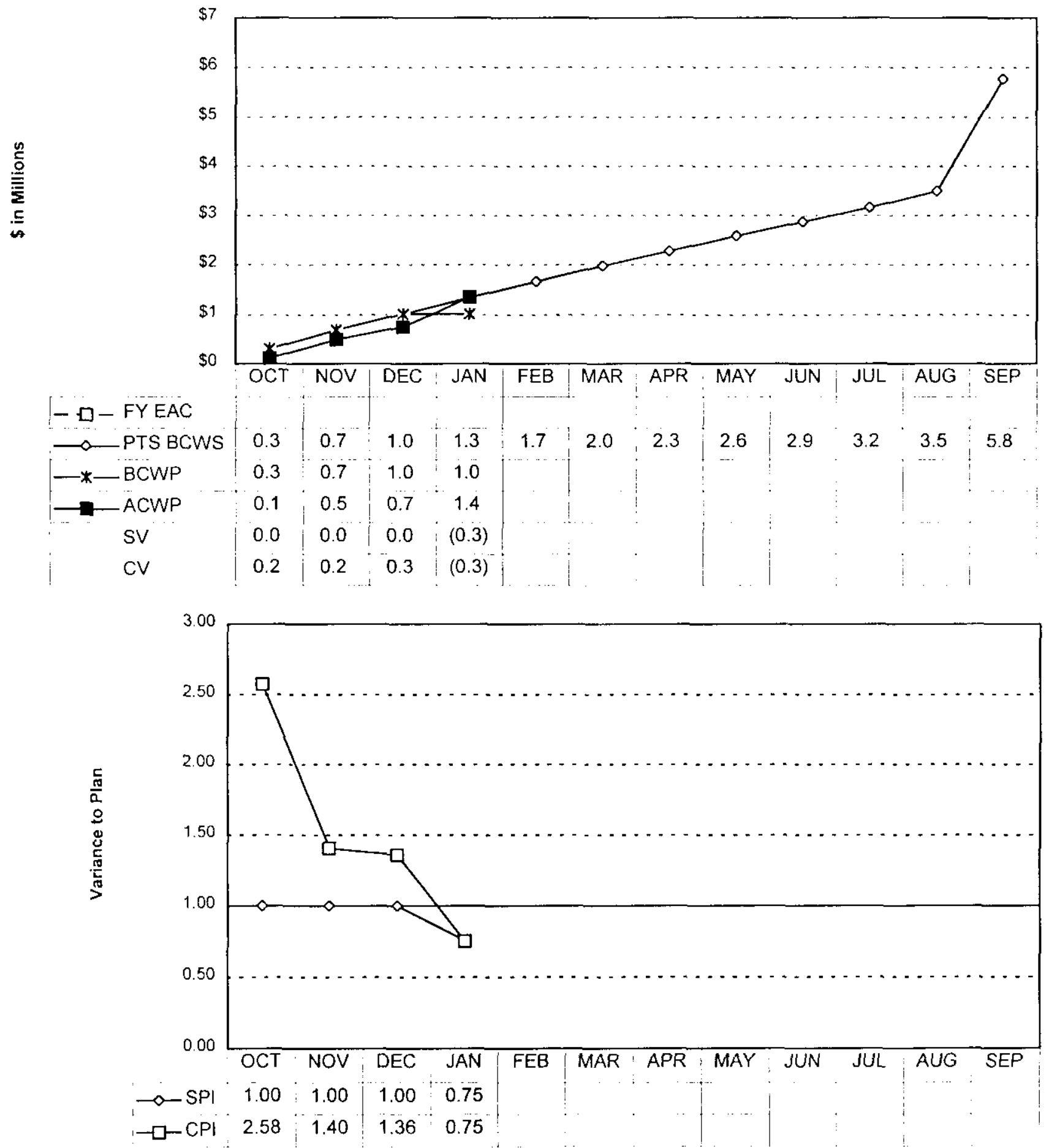
1.11

PBS

OTO2 Transportation
\& Packaging

Sub-Total OTO2

WM07

$\begin{array}{ll}\text { Waste } & \text { Expense } \\ \text { Minimization } & \text { CENRTC } \\ & \text { GPP/LI }\end{array}$

Sub-Total WM07

OT06 Emergency
Preparedness

Expense
CENRTC
GPP/LI

Sub-Total OT06

Total

\begin{abstract}
Expense
CENRTC
\end{abstract}

Total

\section{National Programs}

WBS 1.11

PCW
BCW
0.
0.0
0.0
0.6

\begin{tabular}{ll}
0.7 & 0.5 \\
0.0 & 0.0 \\
0.0 & 0.0 \\
\hline 0.7 & 0.5
\end{tabular}

0.0

0.0

0.0

$\frac{0.0}{0.0}$

$\frac{0.0}{0.0}$

1.3

0.0

1.0

0.0

$\frac{0.0}{1.0}$

$\frac{0.0}{1.3}$

\begin{tabular}{c} 
ACWP \\
\hline 0.5 \\
0.0 \\
$\frac{0.0}{0.5}$
\end{tabular}

0.5

0.6

0.0

$\frac{0.0}{0.6}$

$0.3 \quad 0$.

0.0

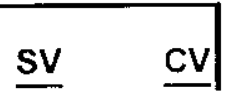

AUTH

PTS

BSLN

BCWS

0.0

2.0

(0.2)

0.0

0.0

0.0

$\frac{0.0}{(0.2)}$

$\frac{0.0}{0.0}$

0.0

0.0

$\frac{0.0}{0.0}$

$\frac{0.0}{2.0}$

(0.2)

(0.0)

3.8

3.8

0.0

0.0

0.0

0.0

$\frac{0.0}{(0.2)}$

0.0

$\frac{0.0}{3.8}$

$\frac{0.0}{3.8}$

0.0

(0.3)

0.0

0.0

0.0

0.0

0.0

0.0

$\frac{0.0}{0.3} \quad \frac{0.0}{0.0}$

$\frac{0.0}{(0.3)}$

$\frac{0.0}{0.0}$

$\frac{0.0}{0.0}$

\begin{tabular}{l}
1.4 \\
0.0 \\
0.0 \\
\hline 1.4
\end{tabular}

(0.3)

(0.3)

3.8

5.8

0.0

0.0

0.0

0.0

$\frac{0.0}{(0.3)}$

$\frac{0.0}{(0.3)}$

$\frac{0.0}{3.8}$

$\frac{0.0}{5.8}$

\$IN MILLIONS 


\section{Cost Variance Analysis: (-\$0.3)}

WBS/PBS

1.11/OT06

Description/Cause: There is a $\$ 0.3$ unfavorable cost variance.

Impact: No impact, once the budget is loaded in the system.

Corrective Action: Enter the BCWS into the system.

\section{Schedule Variance Analysis: (-\$0.3)}

\section{WBS/PBS}

1.11/ WM07

\section{$\underline{\text { Title }}$}

\section{Waste Minimization}

Description /Cause: The unfavorable schedule variance of $\$ 0.2 \mathrm{M}$ (40 percent) is due to plant work that has a higher priority than Return On Investment (ROI) projects.

Impact: No Impact.

Corrective Action: Carryover will be used to continue site and ROI projects next fiscal year. 


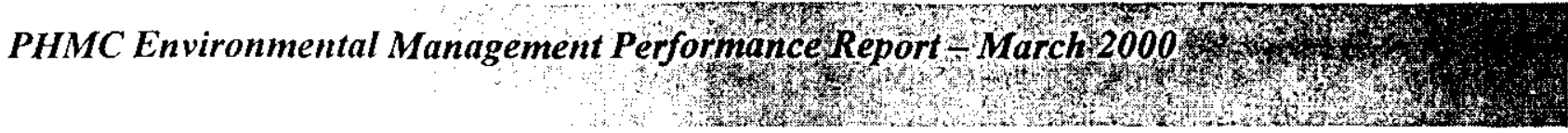

\section{GLOSSARY}

Actual cost of work performed (ACWP): The actual cost incurred and applied or distributed for the work performed within a given time period. It includes all labor categories, material, any other direct costs, subcontract work, and function overhead.

Approved baseline: The budget authorized to perform the workscope that has been agreed upon by the customer and the contractor(s). It is portrayed in the Multi-Year Work Plan with all approved changes. This baseline may or may not be fully funded, and could be more or less than the compliance baseline.

Budget at completion (BAC): The sum of budgets established to complete a program and/or project or any component of a program and/or project.

Budgeted cost of work performed (BCWP): The value for completed work measured in terms of the planned budget for that work. It is synonymous with earned value.

Budgeted cost of work scheduled (BCWS): The time-phased budgeted value of work scheduled to be accomplished over a given time period. The BCWS for a total cost account through its entire period of performance is equal to the BAC for the cost account.

Carryover Workscope: The estimated dollar amount of the workscope that was not completed during the fiscal year and which will be carried over and completed in the next fiscal year.

Compliance baseline: The budget that is required to perform the workscope necessary to be in compliance with State and Federal regulations, enforceable agreement milestones, and DNFSB milestones. The level of activity required to be in compliance assumes sufficient funding. Note: Because approved baselines are considered to be compliant, this column will likely be eliminated.

Contract Inherited: The assumed budget for the planned scope of work at the time a new contract is signed by the company responsible for performing the work.

Cost variance (CV): The difference between $B C W P$ and $A C W P(C V=B C W P-A C W P)$. At any time, it shows whether the work actually performed has cost more or less than the amount budgeted for the same work.

Cost Performance Indicator (CPI): The CPI is the ratio of BCWP to ACWP, or (BCWP/ACWP).

Earned value (EV): The periodic, consistent, and objective measurement of work performed in terms of the budget planned for that work. The EV is synonymous with the BCWP and it is compared to the BCWS to obtain schedule performance and to the ACWP to obtain cost performance. 


\section{GLOSSARY (CONTINUED)}

Estimate at completion (EAC): Cost allocated to the work breakdown structure element to date, plus the estimate of costs for authorized work remaining. Authorized work remaining includes any undistributed budget.

Fiscal Year Spending Forecast (FYSF): The estimated total that will be spent from October through September (current Fiscal Year).

Funding carryover and new Budget Authorization (BA): This funding represents both the funding allocated to perform workscope planned in the prior fiscal year, not completed, and approved to be performed in the current fiscal year, as well as new BA to perform the approved baseline workscope.

Funding target: The level of funding that is anticipated (as a result of the Integrated Priority List process) in a given Fiscal Year based on an assumed funding level for the Site.

Multi-Year Work Plan - 10/1/XX: The Project's approved cost/schedule/technical baseline at the beginning of the fiscal year.

Progress Tracking System (PTS) - The standard reporting tool for the Office of Assistant Secretary for Environmental Management (EM). This system tracks program activities, accomplishments, and resources on a monthly basis to consistently measure program progress.

Schedule Performance Indicator (SPI): The SPI is the ratio of BCWP to BCWS, or (BCWP/BCWS).

Schedule variance (SV): The difference between BCWP and BCWS (SV = BCWP - BCWS). At any time, or for a given period of time, it represents the difference between the planned dollar value of work actually accomplished and the value of the work scheduled to be accomplished.

Work breakdown structure (WBS): A product-oriented family tree division of real estate, hardware, software, services, and data products that organize, define, and display all of the work to be performed in accomplishing the program and/or project objectives. 